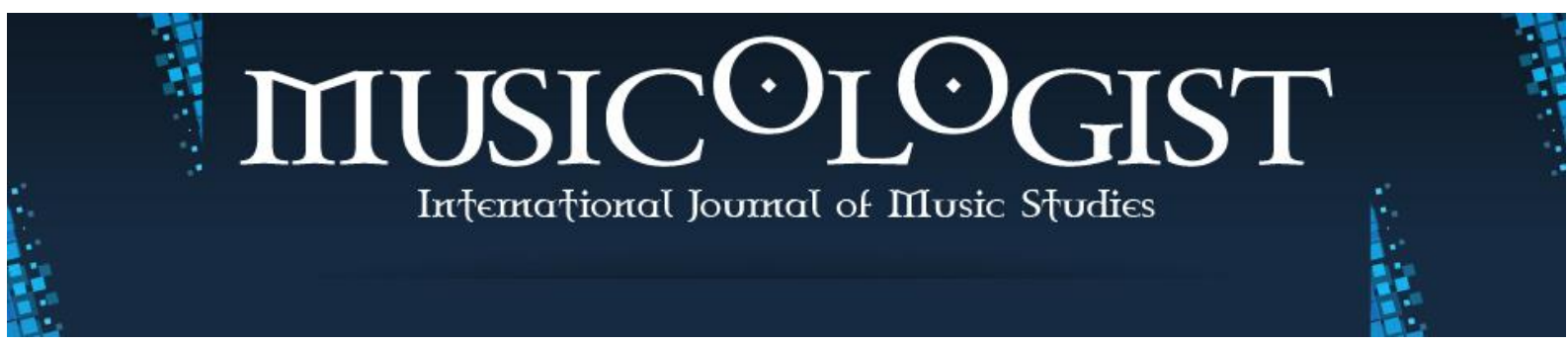

Trabzon University State Conservatory @ C 2017-2021

Volume 5 Issue $2 \quad$ December 2021

Research Article

Musicologist 2021.5 (2): 187-239

DOI: $10.33906 /$ musicologist.986502

\author{
ACHILLEAS CHALDAAKES \\ National and Kapodistrian University of \\ Athens, Greece \\ axaldaiak@music.uoa.gr \\ orcid.org/0000-0002-0733-3508 \\ EVANGELIA CHALDAEAKI \\ National and Kapodistrian University of \\ Athens, Greece \\ evangeliach@yahoo.gr \\ orcid.org/0000-0003-0398-3711
}

SOCRATES LOUPAS

National and Kapodistrian University of

Athens, Greece

socratesloupas@gmail.com

orcid.org/0000-0002-3663-1117

\title{
Historico-musicological Aspects of K. A. Psachos's Archive ${ }^{1}$
}

\begin{abstract}
The purpose of this paper is to present some historico-musicological aspects of the archive of K. A. Psachos. It brings to light some of the obscure or lesser-known aspects of his biography, his oeuvre and his general activities following his three major life events: his upbringing, education and vocational training in Istanbul, his relocation and professional establishment in Athens and the realization of a lifetime goal, the construction of a Byzantine Music pipe organ in Munich. The article is illustrated with digitized archive material and supplemented by transcriptions of K. A. Psachos's handwritten Byzantine Notation, epistles and notes in Greek.
\end{abstract}

KEYWORDS
Konstantinos Psachos
Greek Ecclesiastical
Music
Psachos's archive
Byzantine notation
manuscripts
Panharmonium organ

\footnotetext{
${ }^{1}$ This publication explores the results from the research program "Digitalization, Documentation and Promotion of the Archive of K. A. Psachos", co-funded by the European Union and Greek national funds through the Operational Program "Human Resources Development, Education and Lifelong Learning" (NSRF 2014-2020), under the call "Supporting Researchers with an Emphasis on Young Researchers Cycle B" (MIS: 5047970). The paper was also presented in the IAML Online 2021 70 $0^{\text {th }}$ Anniversary Congress (26-30 July 2021); the first part of the present paper, the one written by Achilleas Chaldæakes, was also presented during a conference held in Athens (on 29 March 2014) on the occasion of the 560-year anniversary (1454-2014) of the establishment of the Phanar Greek Orthodox College/Great School of the Nation [Özel Fener Rum Lisesi]. The authors would like to express their gratitude to Photini Downie Robinson, who kindly undertook the English Proofreading of the text of the present paper.
}

Received: August 24, 2021; Accepted: November 27, 2021 


\section{Introduction}

Konstantinos Alexandrou Psachos was born in 1869 in Mega Revma [Arnavutköy], Constantinople [Istanbul] and died in 1949 in New Smyrna, Athens (Chaldæaki, 2018b: 35-36). He was a multi-faceted scholar of international status and recognition; he was a musician, musicologist, composer, music teacher, researcher, writer, as well as an inventor of an Organ. He played a leading role in the restoration of Byzantine Music, and he is undoubtedly recognized today as the academic founder of the disciplines of Byzantine Musicology and Music Folklore. He left behind a huge oeuvre, consisting of books and articles, pertaining to the fields of Byzantine Musicology, Ethnomusicology, Folklore, History, etc.; it is an 'academic treasure' which K. A. Psachos always supported by his numerous lectures and the parallel organization of relevant concerts.

K. A. Psachos collected and organized all his scholarly and artistic activities, both published and unpublished elements of his life's work, in his personal archive, which remains at his residence (Loupas, 2013). The archive as a whole was closed and inaccessible for research for about 50 years after his death. It includes excerpts and drafts of his publications (books, articles, lectures, musical scores), his correspondence, personal notes, and other specialized archival material, mainly of Byzantinemusicological interest or related to Folklore and Historical issues. K. A. Psachos had carefully and methodically arranged and stored his archive in large hard paper folders following his fields of work and interest. The folders were labeled by K. A. Psachos himself to identify their content, e.g., Student Notebooks, Asian Music, Delphic Festivals, Folk Songs, Correspondence, Lectures, Notes, Athens Conservatoire, Ancient Script Notes, Organ, Drafts, Press. The archive was catalogued according to K. A. Psachos's original classification. The digitization and indexing of the archive has produced more than 50.000 digital files.

\section{Istanbul (Achilleas Chaldæakes)}

The activities of K. A. Psachos in Istanbul are not entirely unknown to us; sufficient elements are pointed out and discussed in the extant relevant bibliography, both in the older (Dragoumis, 1974: 313-314; 1990: 78-79; Hadzitheodorou, 1978: เ $\delta^{\prime}[14]-\kappa \gamma^{\prime}[23]$; Romanou, 1996: 14-15, note 26; Mamoni, 2000: 90-93), as well as in the recent one (Chaldæaki, 2018b: 35-45). 
However, in searching the K. A. Psachos's archive for further unknown elements about his activities in Istanbul, the researcher is indeed provided with a multitude of new and largely unknown documents concerning his multifaceted tasks there; ${ }^{2}$ indicative aspects of those documents are presented below:

\section{Student notebooks}

Of exceptional interest are several student notebooks found in K. A. Psachos's archive; they are student notebooks of K. A. Psachos himself, but there also are some notebooks

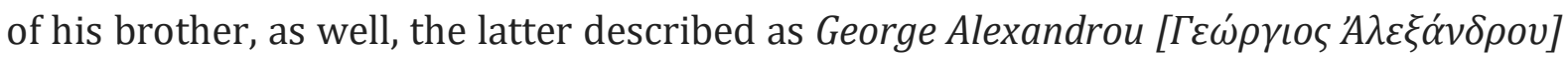

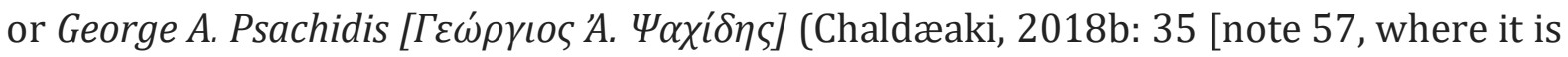
mentioned that he was born in 1866] \& 37 [note 60]). These notebooks contain informal student notes or attentive copies of several school texts, as well as other relevant student essays of both brothers.

Some student notebooks of K. A. Psachos himself are particularly noteworthy; they are notebooks where one can see K. A. Psachos's name written down by his hand on their

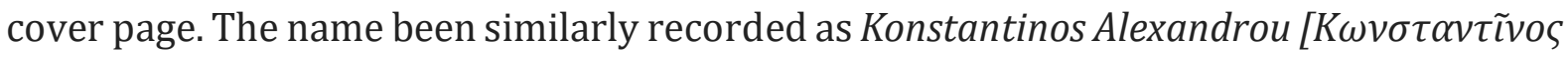

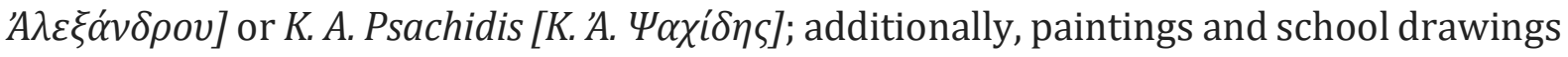
from his childhood, obviously made during his leisure, may be seen in the same notebooks; occasionally, the mentioned notebooks are stamped with K. A. Psachos's characteristic special oval seal [facs. 1], bearing at the top a cross, in the middle his initials

\footnotetext{
${ }^{2}$ Cf. Chaldæakes, 2014b: 377-378; there, a very important and (until then) unknown fact concerning his musical studies was pointed out; it refers to a note he had written on the back of the cover page of one of the musical books in his library, where K. A. Psachos clarified the following: The first musical text from which I started my musical studies in the Patriarchal Central Clergy School, where I was an inmate [Tò $\pi \rho \tilde{\omega} \tau o v$

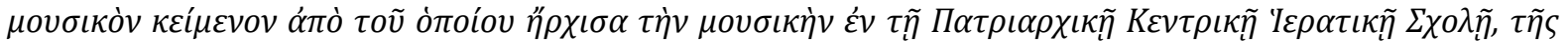

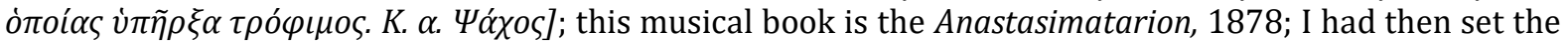
year 1878 as a safe terminus post quem, not only concerning - specifically - the determination of the date of the attendance of K. A. Psachos at the mentioned Clergy School, but also - generally - for the time period in which he systematically started studying Byzantine Music. Now, we know (due to recent research published by Chaldæaki, 2018b: 37-39) that the attendance of K. A. Psachos in the Patriarchal Central Clergy School began in the year 1881, a year during which this school was still located on the island of Halki [Heybeliada]. In the following year (1882), the school "was transferred to the community of Eksiliporta (Lotza), near to the Holy Fountain (Hagiasma) of the Church of St. Mary of Blachernae"; the last fact is confirmed by a student notebook of K. A. Psachos (mentioned later) with the following title: The Notes of Botanica of the second grade student of the Central Clergy School located in Balat area of Istanbul,

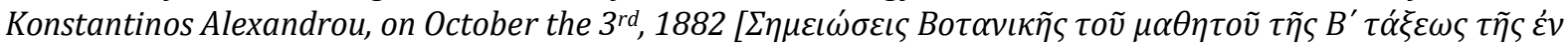

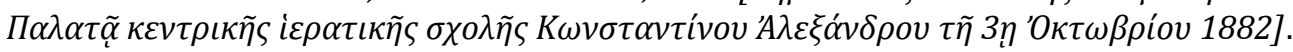


$[K . A$.$] , written between laurels, and at the bottom an inscription of the year 1879$ (Hadzitheodorou, 1978: เ $\delta^{\prime}[14]$; Chaldæaki, 2018b: 178).

Through the aforementioned notebooks, one can undoubtedly observe the various subjects of K. A. Psachos's apprenticeship in his schools; for example, while he was a student at the Central Clergy School located on the island of Halki [Heybeliada], he studied

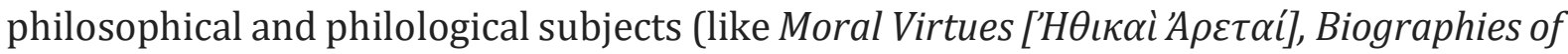

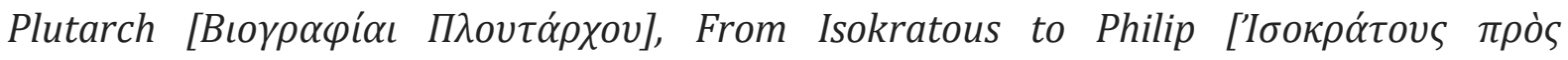
$\Phi i ́ \lambda \iota \pi \pi \circ v]$, etc.), and also took some courses in mathematics. It should also be noted that K. A. Psachos's student notes on the abovementioned subjects include, some drafts of formal letters, ${ }^{3}$ and even his first drafts of several student works, ${ }^{4}$ as well as some of his early translation efforts.

Furthermore, additional musicological information is unexpectedly found in this exclusively informal material which is contained in these student notebooks; for instance,

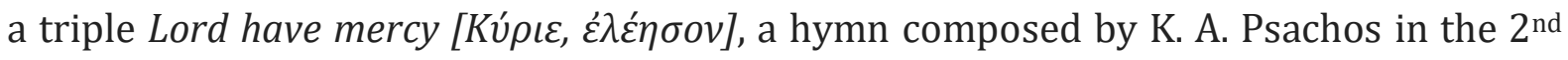
Mode of Byzantine Music and spontaneously written on the cover page of one of his student notebooks, specifically a notebook with the following title: The Notes of Botanica of the second grade student of the Central Clergy School located in Balat area of Istanbul,

\footnotetext{
${ }^{3}$ For example (the text is written in Greek):

'H ع́v Xó̉

$\Sigma \varepsilon \beta \alpha \sigma \tau \eta \dot{~} \mu$ ov $M \tilde{\eta} \tau \varepsilon \rho$

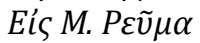

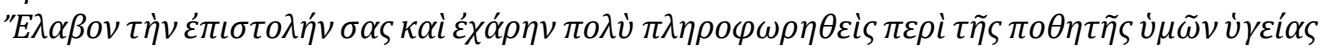

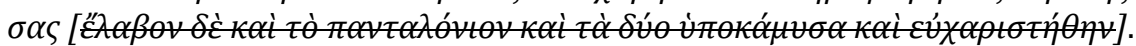

Another example (the text is also written in Greek):

$\Phi i \lambda \varepsilon$,

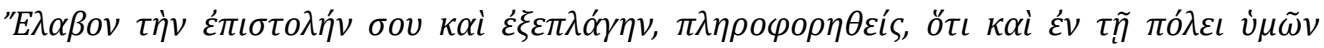

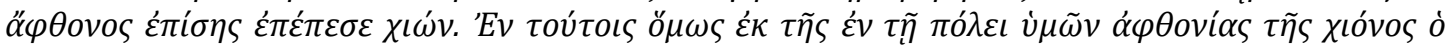

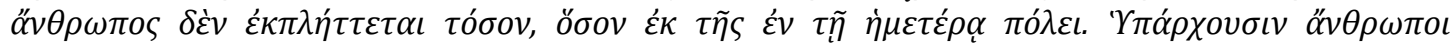

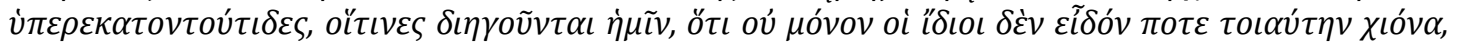

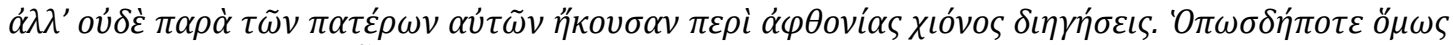

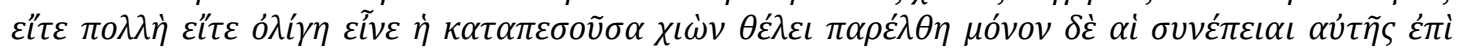

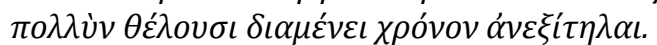

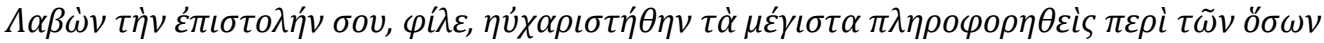

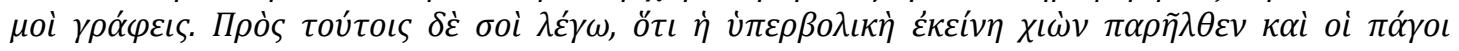

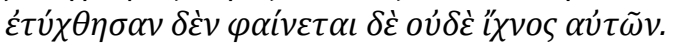

${ }^{4}$ For example (the text is once again written in Greek):

'Ү

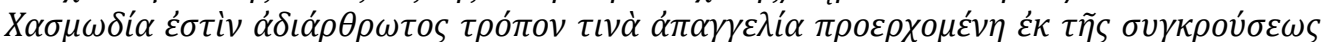

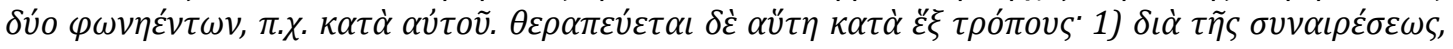

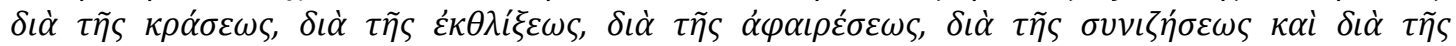

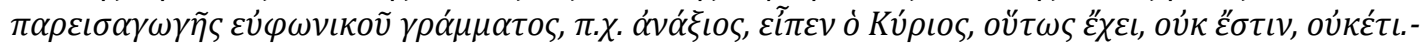




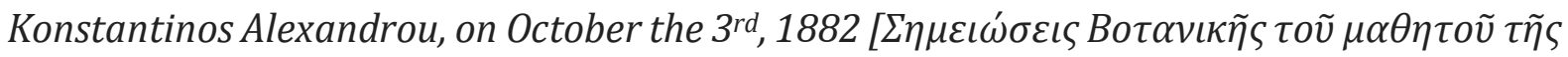

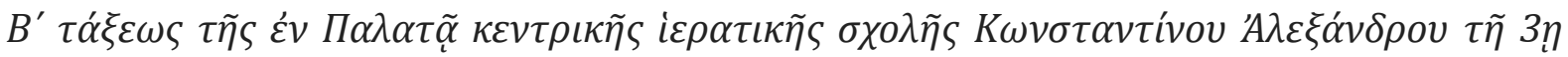

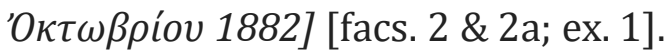

Finally, the following draft (definitely written later) of his epistle is of crucial importance, as it deals with a notorious Byzantine Music book entitled The Key of the Ancient Notation of the Byzantine Music, written by Panagiotes Kiltzanides: ${ }^{5}$

\section{Honorable Director}

It was with great pleasure to be informed that the very honored expatriate in Russia Gregory Marasles took over the expenses of the publication, in the 'Marasleios Library', of the manuscript of the late Hadzi Panagiotes Kiltzanides from Bursa, a book titled: 'The Key of the Ancient Notation of the Byzantine Music'. The title itself is sufficient in order for someone to understand the difficulties that imply the printed publication, particularly for the very first time, of a music book written according to the ancient notation of Byzantine Music. That is because nearly none of the Greek musicians really know the complexity of the ancient notation of Byzantine Music and nearly none of the Greek publishers know the way to typographically use this notation. For this purpose, as I anticipate the most immediate publication of this welcoming book, which will be of great help for those who deal with the ancient notation of Byzantine Music, it is my duty to present to those in charge the following opinion. The printed publication of the main music part of the book will be quite expensive, due to the difficult and entirely original nature of the work. Would it not be preferable for the pure music part of the book to be published using the 'facsimile technical method', according to which the publisher would have to typographically

${ }^{5}$ The Greek text of the epistle is as follows:

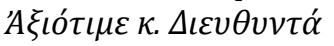

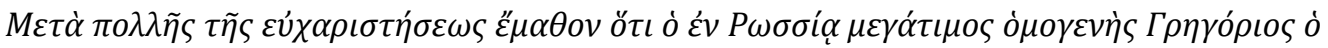

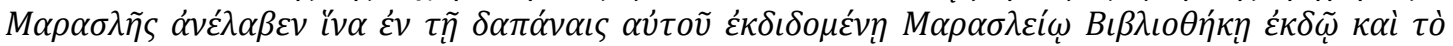

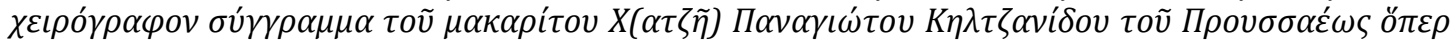

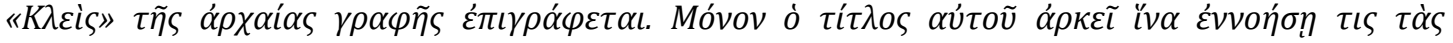

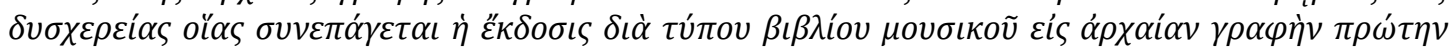

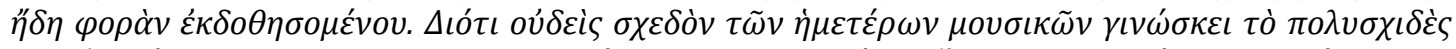

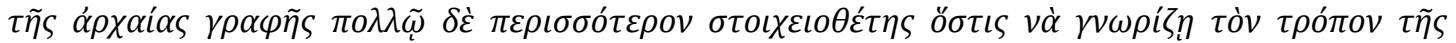

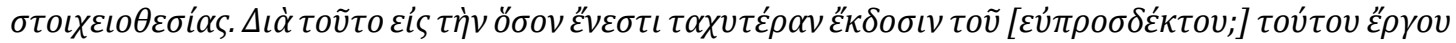

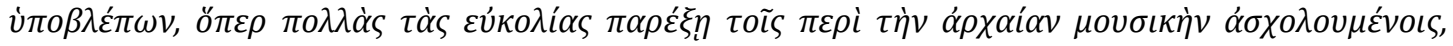

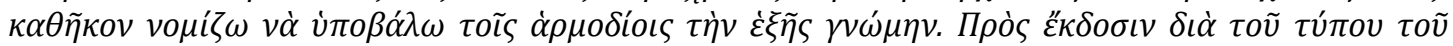

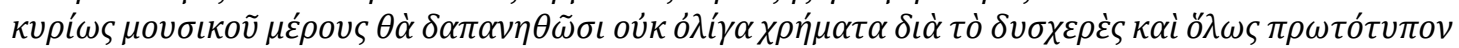

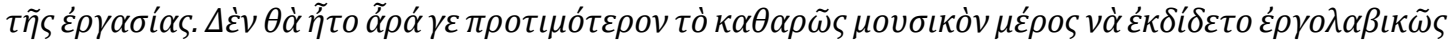

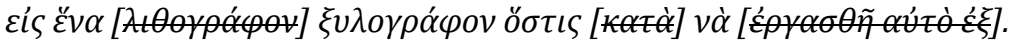

About the above-mentioned book cf. Kiltzanides, 1886: $\alpha^{\prime}[1]-\gamma^{\prime}[3]$; Psachos, 1905; Psachos, 1978: 247-248, note 81; Stathis, 1978: 16-18, 40-41, note 2. 
imitate the way the ancient notation was written in the existing manuscripts of Byzantine Music?

\section{Documentation of Byzantine Music Compositions}

Of even greater interest is another notebook - preserved in K. A. Psachos's archive - under the following title: Miscellany (from my childhood), Konstantinos Alexandrou [( $\pi \alpha \iota \delta \iota \kappa \alpha ́$

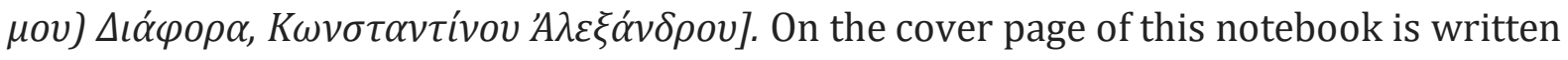

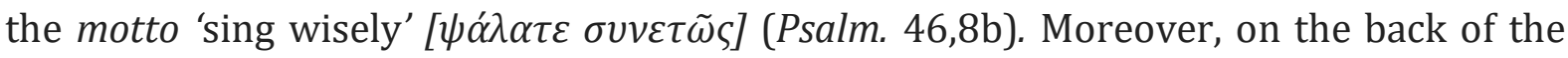
cover page, one can also find a later note of K. A. Psachos, through which he specifies what the notebook contains: My first attempts (at the age of 18) to document those heard by my uncle, Dimitrios Papadopoulos, who inspired in me the love for music [Ai $\pi \rho \tilde{\omega} \tau \alpha \iota$

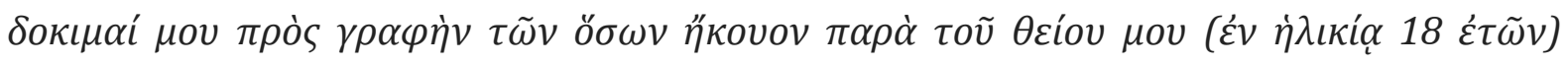

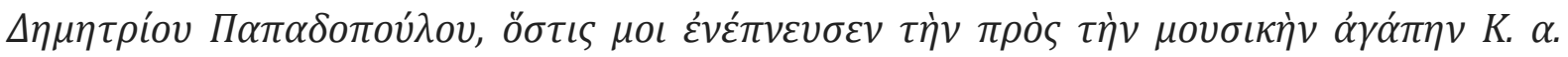
$\Psi \alpha ́ x o \varsigma]$.

The musical dictations which are documented in this specific notebook are definitely remarkable; some of them have subsequently been corrected by K. A. Psachos himself,6 because, as he points out in another note found in his archive: the written Byzantine Music compositions, transcribed by me after a recitation by my uncle, Dimitrios Papadopoulos, are full of misspellings, because I wrote them while still a child, ignorant

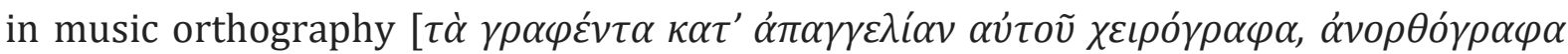

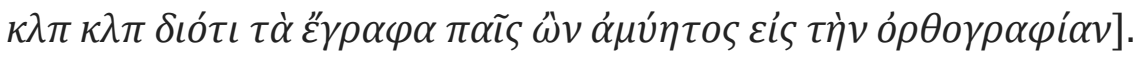

Additionally, in the aforementioned note found in his archive, ${ }^{7} \mathrm{~K}$. A. Psachos characteristically clarifies the following information: In my father's house, there was a great 'musical treasure'. He was my notorious uncle, the brother of my mother's mother, Dimitrios Papadopoulos [...] Being a child, I was attracted by the sweetness of his voice and I admired him without knowing why. But, when I took music lessons, while I was a student at the clergy school, I became able to somehow understand what it was that was pleasing me. Then I opened my eyes and, during the day and night, I was hearing what he was softly chanting; thus I was initiated in the performative style according to how he

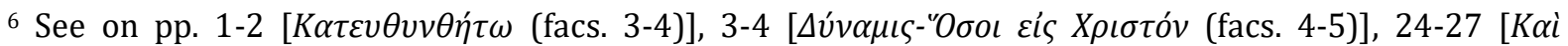

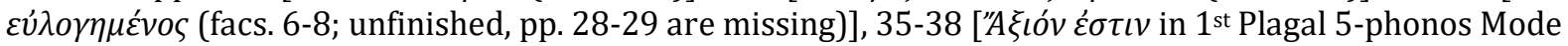
(facs. 8-10)].

7 See the full text of the above-mentioned note published by Hadzitheodorou, 2013: 217-218, note 1 \& Chaldæaki, 2018b: 39-40. Cf. Hadzitheodorou, 1978: ı' $\varepsilon^{\prime}$ [15].
} 
was chanting. I began to roughly write what he was chanting, in which, to some degree, was evident the imagination and the performing manner of the vocal approach of an entire series of compositions, which he had always recalled from memory, without fail. While he was performing, he usually said to me: 'This is how Costakis, the protopsaltes/or Stephan/or Onoufrios, etc., used to perform this composition'...8

So, today one has the unique opportunity to possess and evaluate the mentioned original musical manuscripts of K. A. Psachos. By way of these musical scores (even through those which K. A. Psachos himself avoided or did not consider it necessary to correct, with his usual later interventions, written in pencil), one actually has the ability to 'listen' to some famous Byzantine Music chanters; for example, Konstantinos from Istanbul [Byzantios] the protopsaltes, John from Nichori [Yeniköy] the protopsaltes, Stefan Koutras, Peter from Prinkipos [Büyükada], Onoufrios from Istanbul [Byzantios], etc.; their live performative style is 'delivered' to the contemporary audience by 'the voice' of Dimitrios Papadopoulos (i.e. K. A. Psachos's uncle), as that 'voice' is written down in the form of the musical dictations in these notebooks.

At this point, a characteristic example, documented in the mentioned notebook (pp. 8-10 \& 41-44), should be paradigmatically pointed out; it is a specific composition of Dimitrios

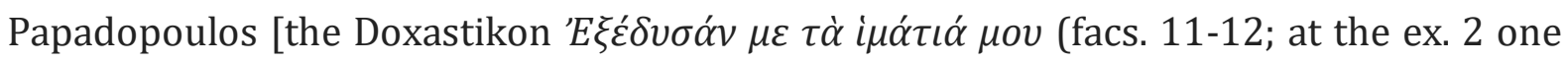
can see the same composition transcribed under a notational revision)] sung during the Matins of the Holy Friday service; its beginning is marked with the aforementioned seal of K. A. Psachos; it is a seal that includes the date 1879, which is the only chronological indication found in this notebook. However, this date must not be closely related to the above-mentioned information, i.e. the one found on the back of the cover page of the same notebook, according to which K. A. Psachos documented what is written there 'at the age

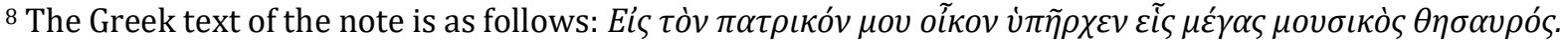

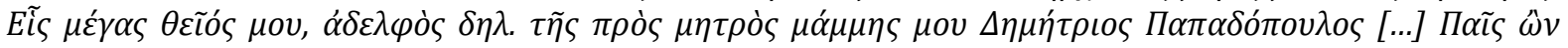

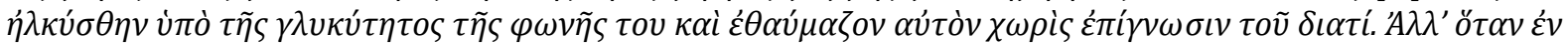

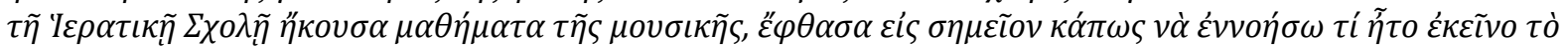

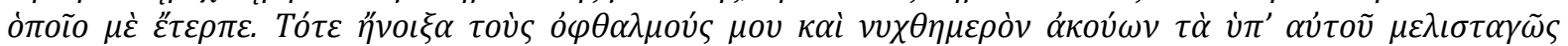

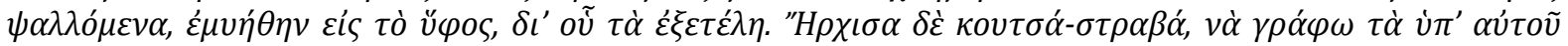

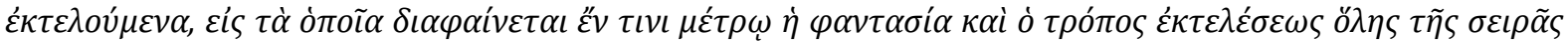

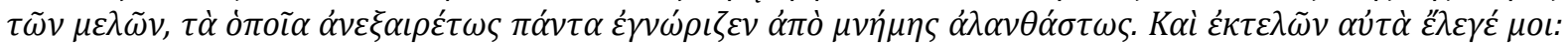

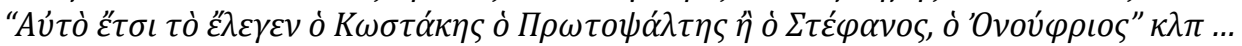


of 18'; born in 1869, K. A. Psachos was 10 years old in 1879 (Chaldæaki, 2018b: 39-40, note 72 ).

Finally, there must be a special mention of the fact that the musical material of the present notebook concludes (pp. 47-49) with a musical score of a Şarkı composed by the Hânende

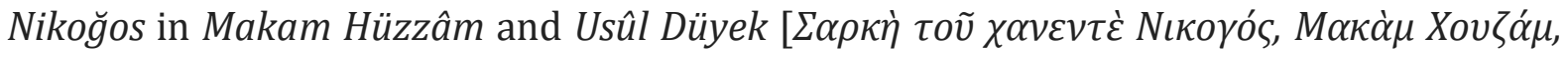

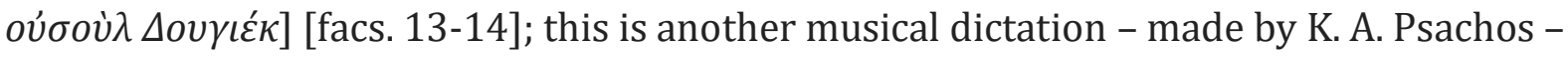
of a well-known sample of Ottoman Music. ${ }^{9}$

\section{Teaching and artistic activities}

It is impossible not to focus one's attention on a small collection which has also been identified in K. A. Psachos's archive; this collection consists of School chants taught in several schools of Constantinople (specifically, in the Girls' School of the Metochion of the Holy Sepulchre in Phanar, Istanbul, the Schools located in Mouchlion and Vlanga [Yenikapi] areas of Istanbul etc.) ${ }^{10}$.

The specific samples are written down in the Byzantine Music Notation by K. A. Psachos himself (while it should also be noted that many of them are accompanied by the

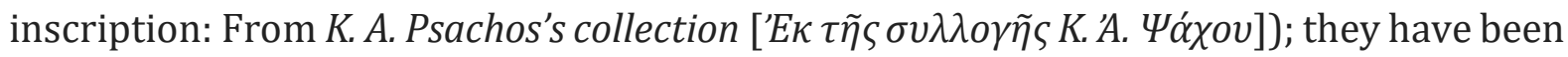
edited to be performed by two voices. This effort reveals another - perhaps less wellknown and prominent - aspect of K. A. Psachos's artistic activities: one, which embraces and heals both Eastern and Western Music, while observing the ideological trends and the musical behaviors of the given time frame, without barriers, prejudice, and discrimination.

\footnotetext{
${ }^{9}$ The above-mentioned composition is the Hüzzâm Şarkı Niçün nâlendesin böyle composed by Nikoğos Ağa in Usûl Düyek; for the said composer see at the following site: https://www.notaarsivleri.com/NotaMuzik/nicin nalendesin boyle gonul derdin nedir soyle.pdf [accessed 31 July 2021]; also, musical scores of the composition under discussion see at the following sites: https://www.neyzen.com/nota arsivi/02 klasik eserler/046 huzzam/nicin nalendesin.pdf [accessed 31 July 2021] \&

https://www.notaarsivleri.com/NotaMuzik/nicin nalendesin boyle gonul derdin nedir soyle.pdf [accessed 31 July 2021]; the present author would like to thank Gerasimos Papadopoulos for providing useful information, as well as for transcribing the aforementioned musical score into the Staff Notation [ex. 3].

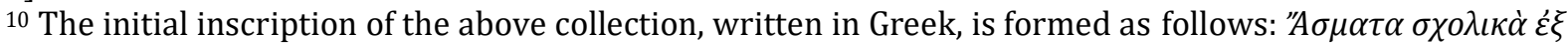

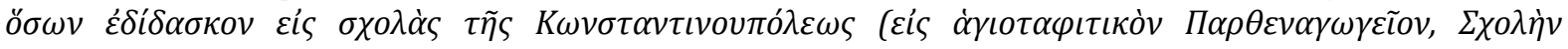

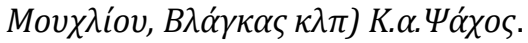


Memorable is also a special folder of carefully selected pieces of newspapers and magazines edited in Istanbul which K. A. Psachos methodically kept, and which is found today in his personal archive; there, among other testimonies, one can find several

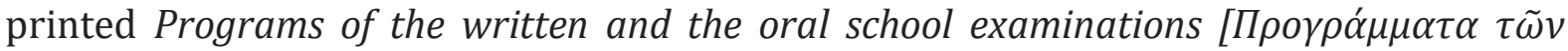

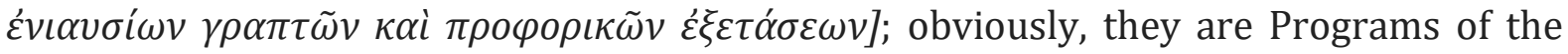
examinations that took place in the aforementioned schools, where K. A. Psachos worked as a teacher, especially in the 'Girls' School of the Metochion of the Holy Sepulchre in Phanar, Istanbul'11. In those Programs, K. A. Psachos is indicated as a teacher of a variety of school subjects, such as: Theology, History, Geography, Anthropology, History of the Eastern Nations \& Greek. ${ }^{12}$

Moreover, in a chronographic note published in the newspaper Constantinople

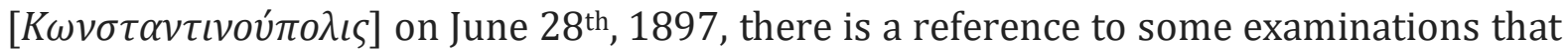
took place (during that year) in the above-mentioned Girls' School of the Metochion of the Holy Sepulchre in Istanbul; in the mentioned note one can read that 'the superior class was distinguished in the Greek language (Plato's Kriton), examined by the professor of Phanar Greek Orthodox College/Great School of the Nation [Özel Fener Rum Lisesi], Evangelos Alexopoulos, who, in public, declared worthy of congratulation the one who taught Greek Literature in this class, i.e. the well-educated Konstantinos Psachos'13. This is a fragment, kept in K. A. Psachos's archive, which he additionally has copied - writing it by his hand - on the back of the relevant piece of paper.

\section{Athens (Evangelia Chaldæaki)}

K. A. Psachos's biography in Athens is widely known within the academic community. The existing bibliography goes on about matters relevant to his life and work, examined in studies of respective papers, both in general (Anastasiou, 2008; Chaldæaki, 2018b; Chaldæakes, 2014a; Dragoumis, 1974; 1990; Hatzitheodorou 1978; Kritikou, 2013; Loupas, 2014; Mamoni, 2000), and with more specific focus (Balageorgos, 2013; Chaldæaki, 2018a; Chaldæakes, 2014a; 2014b; Polimerou-Kamilaki, 2013; Siamakis,

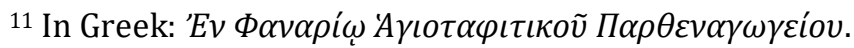

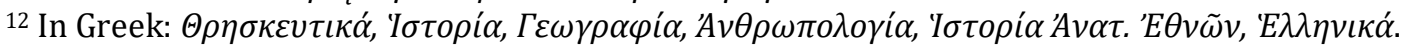

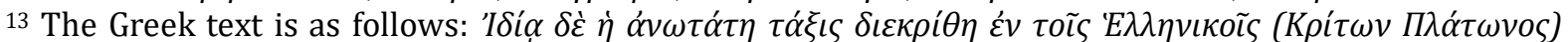

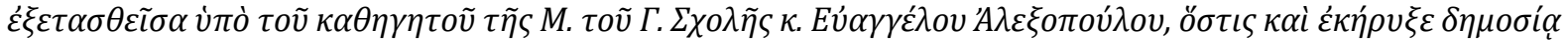

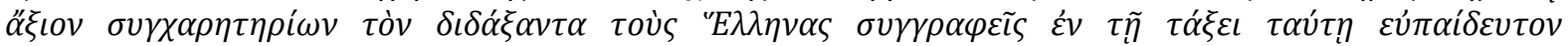

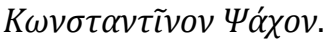


2013; Stathis, 2001; 2013). However, further inquiry to his recently digitized personal archive at his resindence, brought to life facts that enlighten additional historicomusicological aspects of his life.

Specifically, a very important and massive part of his archive is his correspondence. The digitization of this file offered 1,665 digital files, which account for 851 epistles. Of course, these do not represent K. A. Psachos's correspondence in its entirety. There must have been more epistles which might have been destroyed or lost over the course of time. He had also listed some letters in other folders of his archive, where they are more relevant in context, such as files entitled Asian music, ${ }^{14}$ Folk music, etc. The particular epistles include musical records or analyzed subjects, pertaining to the folder where they were categorized. The documents in the folder entitled Correspondence come mostly from places all around Greece, but also Istanbul and Turkey in general, Egypt, where he had family (his brother and some cousins), Europe and the USA. They can be long, numbering in many pages, or short. Also, there are quite a few correspondence texts written on the senders' business cards, and also some telegrams. Epistles of K. A. Psachos to others were also found, which are actually copies of the exact letters he sent, which he wanted to keep in his archive. Many of the documents have some memos of K. A. Psachos written on them, concerning mostly information about when he wrote back to the senders, sometimes giving evidence about their personalities, or referring to when he received the mail, e.g., "I answered on September 28, 1920, They were sent on September 3, This was received on the $18^{\text {th }}$ of the same year." 15

The letters were addressed to K. A. Psachos from friends, colleagues, students and admirers, or from various agencies, such as publishing houses, ministries, associations, etc. The relationship of K. A. Psachos with the senders is indicated by the way they refer to him, e.g. 'Dear sir', 'Sir Musicologist', 'Respected teacher', 'Respected Mr. Psachos', 'My dear friend', 'Brother Konstantinos,' etc. ${ }^{16}$ The correlation can also be deduced by looking into their context, which can be cordial or typical, or by checking the significant number

\footnotetext{
${ }^{14}$ K. A. Psachos's correlation with Ottoman Turkish (Asian, as he called it) Music is something that will concern the writer in the near future, as much new evidence was brought to light from the inquiry in his archive.

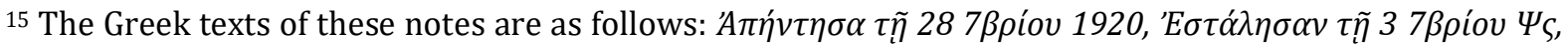

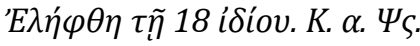

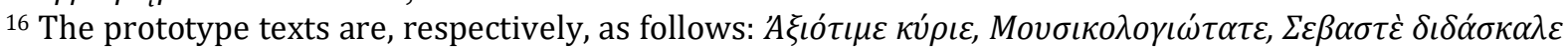

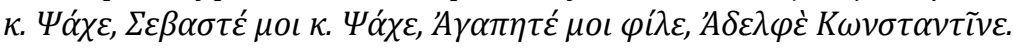


of epistles sent by one person. In general, they cover all the aspects of K. A. Psachos's life in Athens. The correspondents write to him when they are informed of a new achievement or get news about his activities, when they want to get a copy of his work, or engage in frequent communication with him about a specific matter. Hence, we have a window into the most significant aspects of K. A. Psachos's life in Athens, as presented by the testimonies of his correspondence.

\section{Editorial activity}

K. A. Psachos's editorial activity took place mostly in Athens, where he published much of his work, relevant to Byzantine, Greek folk and Asian music. He also wrote editorials for many newspapers and journals about musicological subjects as well as topics related to Folklore Studies, History, Theology, Ethics, and others. These publications concerned archival or field research, his innovative ideas and compositions, and contemporary issues such as opinions published about matters pertinent to his research, historical and cultural events, etc. In the correspondence found in his archive, several sources of information concerning his publications were found. Most of them were letters from people sending him money in order to receive some of his books, or seeking information about them. E.g.:

I am honored to inform you that I have sent you a postal check of 50 drachmas for the value of one book (Liturgical Hymns), not knowing the exact price of it and qualifying that you will receive the rest of the fee ${ }^{17}$.

There were also some epistles of persons writing him that they read several of his newspaper and journal publications and commenting on them, or congratulating him

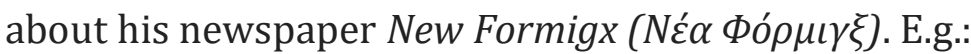

[...] I received the $10^{\text {th }}$ issue (of December) of New Forminx [...] With much pleasure, I read the latest issues and I applaud your endeavors for the country, with which I agree. But as I have written to you before, you must continue to pursue your efforts with patience, until they finally yield results ${ }^{18}$.

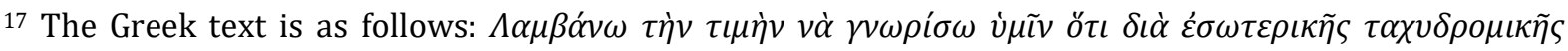

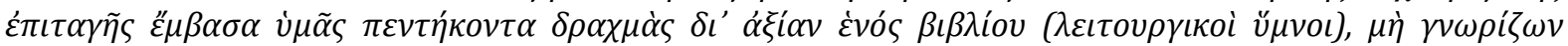

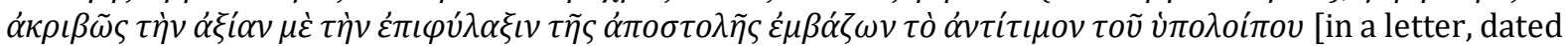
5/8/1927, from D. Zormis].

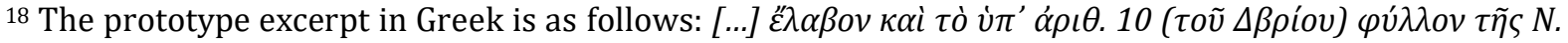

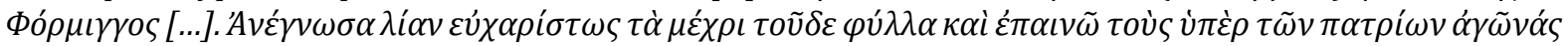

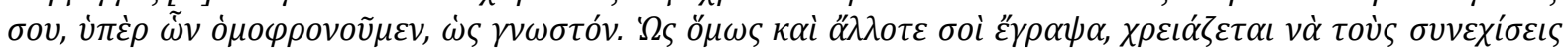


Interestingly, a series of relevant letters sheds light on the existence of a work by K. A. Psachos that seems not to have been published and is still unknown to us, by the title The

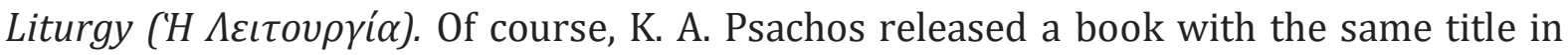
1909 (Psachos, 1909), for which he had won a monetary prize from the Athens Conservatoire (Chaldæaki, 2018b: 114, note 287). The above-referenced work was a different one, intended to be used at the Metropolitan Church of Athens, in order for this church to further represent original Byzantine chanting, while preserving the respective performative style of the Patriarchate of Istanbul [facs. 15]. The Church Committee assigned this work to K. A. Psachos in 1931, seeking to gradually decrease the use of the tetraphonic psalmody (Greek Orthodox Church singing) in that particular church, and to

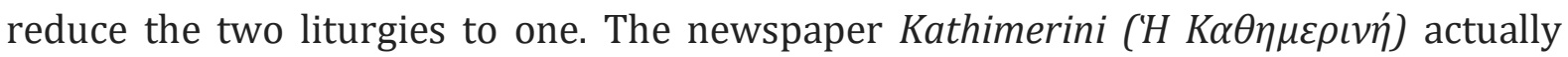

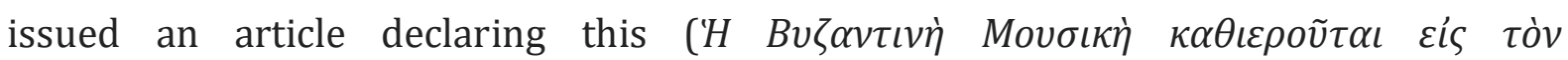

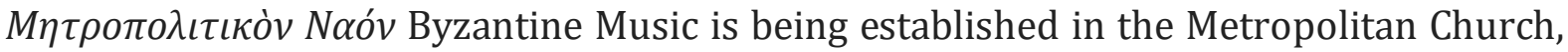
1932). K. A. Psachos received the payment of 10,000 drachmas for this work, and after it was not published, he requested his manuscript back, particularly in the year 1939, claiming intellectual property. Yet, we don't know if his request was ever honored. Sometime later, specifically in 1940, K. A. Psachos received a letter from his friend and classmate Nikolaos Vasiliadis ${ }^{19}$. The actual letter was not found in the archive, but only supporting evidence to it, such as the following memo of K. A. Psachos, written on the relevant envelope [facs. 16]:

The epistle to my childhood friend and classmate doctor Nik. Vasiliadis was written in the cause of a defamation against me to him, caused by Chrysanthos Filippides, who is now, unfortunately, the Archbishop of Athens. The latter was probably outargued and dumbfounded, since later on he was not able to justify himself ${ }^{20}$.

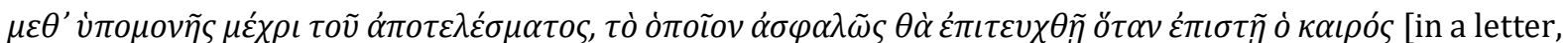
dated 28/1/1922, from Christos Vlachos].

${ }^{19}$ Nikolaos Vasiliadis was one of the frequent pen friends of K. A. Psachos; In Psachos's archive, 35 letters of Vasiliadis were found, dated between years 1885-1886, 1889-1892, 1898, 1906, 1909, 1912, 1920-1921, 1923, 1926, 1928-1931 and addressed from Athens, Mega Revma [Arnavutköy], Istanbul, Smyrna and Aydin.

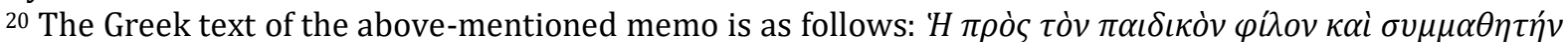

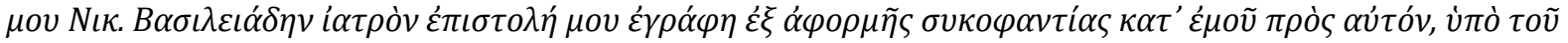

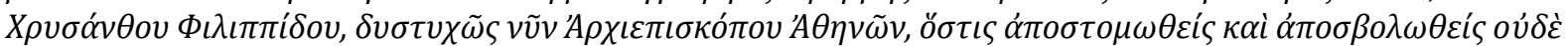

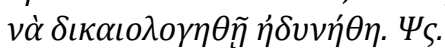


Nikolaos Vasiliadis claimed he was informed that K. A. Psachos received a payment for

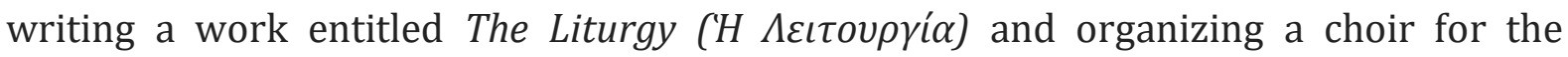
Metropolitan Church of Athens, but he completed neither of the jobs; Psachos wrote back to Vasiliadis, in $20 / 1 / 1940$, clarifying that he was not asked to organize the church's choir; he was only asked to write a work that he in fact had already delivered successfully. He also requested written confirmation from the members of that Church's Committee which he included in this letter (present in the archive).

\section{Teaching activities: Athens Conservatoire and National Music Conservatoire}

In the aforementioned epistle that K. A. Psachos wrote to Nikolaos Vasiliadis, along with the fact that he informed him about the actual incidents and refuted the false accusations, K. A. Psachos also gives information about his life in Athens. He describes how he relocated there, sent from Istanbul with the intervention of the Patriarchate, in order to establish the first Athenian School of Byzantine and Ecclesiastical Music at the Athens Conservatoire. Also, he wrote that upon his arrival he was determined to pursue the career of a teacher, setting aside his profession of a chanter (Greek Christian Orthodox Church cantor).

[...] as you already know, I didn't want to proceed with the profession of a chanter, for sufficient reasons, as I explicitly declared to the Patriarch Joaquim the $3^{\text {rd }}$, who relocated me to Athens. Furthermore, the official Proceedings of the Holy Synods of the Church of Greece and of the Ecumenical Patriarchate confirm that I was sent, upon the request of the Church of Greece, to the headquarters of Byzantine Ecclesiastical Music that was established in 1904 at the Athens Conservatoire, to teach according to the tradition and the 'yphos' (performative style) of the Great Church of Istanbul21.

For some reason, he also adds that he would be willing to resume his position at the Athens Conservatoire or to compose a relevant work, if he were invited to do so by the Church or the State.

\footnotetext{
${ }^{21}$ The prototype excerpt from K. A. Psachos's epistle to Nikolaos Vasiliadis, dated 20/1/1940, is as follows:

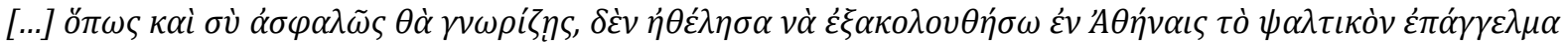

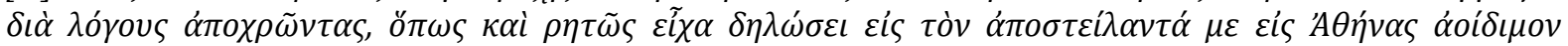

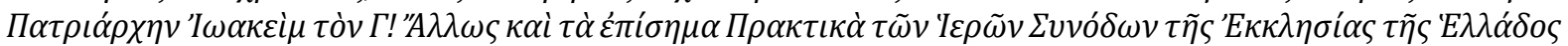

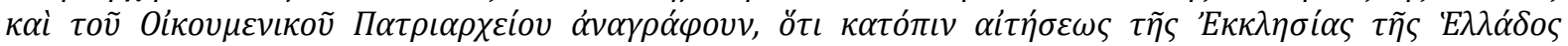

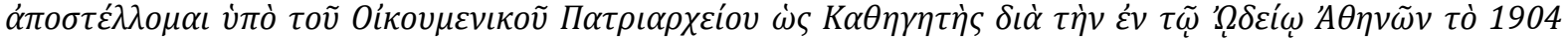

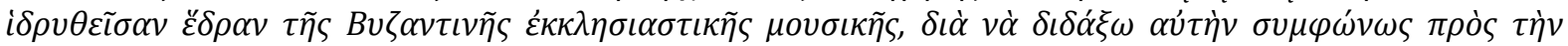

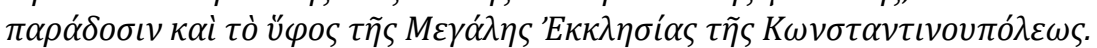


I am amenable to undertake the same position at any moment, either by officially being invited to the School of the Athens Conservatoire, which is recognized by the State and which I created, or by being assigned any auxiliary writing or teaching. This way I could be helpful again, if the State and the Church thought it would be appropriate to use me.22

K. A. Psachos taught at the School of Byzantine and Ecclesiastical Music in the Athens Conservatoire during the years 1904-1919. The curriculum included the instruction of ecclesiastical music as well as history of music, elements of Christian Orthodox Worship, as well as European Music, Greek Folk Music, and Asian Music. He frequently organized concerts and other events with the participation of the students and intended for the annual exams to be conducted publicly. In 1919 he was discharged from his position there, due to arguments that he had with the management of the foundation, regarding general modifications that K. A. Psachos wanted to impose on the School23.

Shortly after, in the same year, he established his own Conservatoire, which he called the National Music Conservatoire, where he taught Byzantine, Greek Folk and Asian Music. The National Music Conservatoire operated until 1922, until various incidents in his life -particularly, an accident that left him bedridden, the beginning of the manufacturing of the Panharmonium instrument in Germany ${ }^{24}$, and the death of his wife Evanthia- forced him to close its doors. At first, this Conservatoire aimed to be in a shared tenancy with the Greek Conservatoire of Manolis Kalomiris, also a member of the Athens Conservatoire staff, where he taught European Music and resigned around the same time that K. A. Psachos did, for similar reasons. This achievement was not completed, as a result of dissonance between the two personalities. These facts are known to us from a letter of Manolis Kalomiris to K. A. Psachos, found in the archive of the musicologist and collector Josef Papadopoulos-Grekas (Dragoumis, 1974: 65). A similar epistle from Manolis Kalomiris was later found in K. A. Psachos's archive, dated 20/9/1919; Kalomiris writes

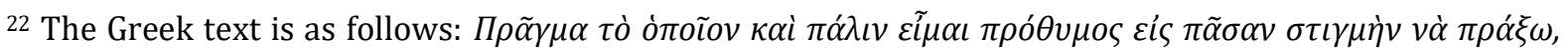

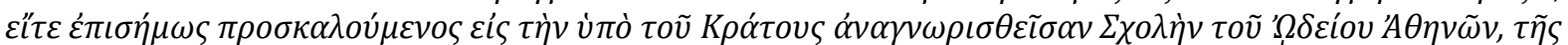

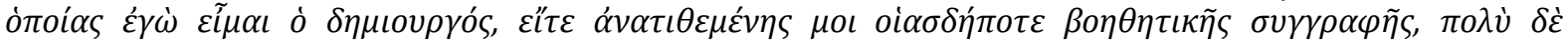

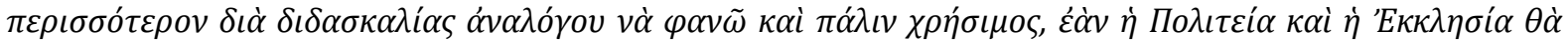
$\dot{\varepsilon} v o ́ \mu \iota \zeta o v \pi \rho o ́ \sigma \varphi о \rho o v ~ v \dot{\alpha} \mu \dot{\varepsilon} \chi \rho \eta \sigma \iota \mu о \pi о \imath \eta ́ \sigma o v v$ [excerpt from the aforementioned epistle from K. A. Psachos to Nikolaos Vasiliadis].

${ }^{23}$ See an analytical description in Chaldæaki, 2018b: 55-63.

24 Panharmonium was an instrument that Psachos designed, along with the mathematician Stavros Vrachamis. This instrument can replicate the micro-intervals of the Greek musical tradition. Further details about that are mentioned in the third part of the present article (the one dealing with K. A. Psachos's activity in Germany).
} 
there that the Greek Conservatoire's Administrative Council agreed to concede two rooms to Psachos for teaching purposes and one more for office utility, under the conditions that he would not instruct lessons that were also provided by the Greek Conservatoire nor teach Greek dances, and that he would not name his school the 'National Music Conservatoire'.

\section{Judicial conflict for the scores of Greek folk songs from Peloponnese and Crete}

Retiring from the Athens Conservatoire in 1919, K. A. Psachos left a matter unresolved, which was later determined in court. This concerned the musical dictations of Greek folk songs and dances, which were collected in two expeditions for fieldwork research, organized by the Athens Conservatoire in Peloponnese in 1910, specifically in the village

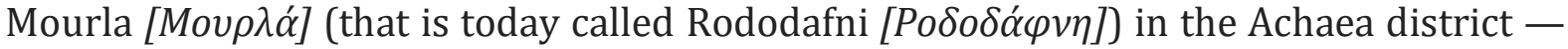
which was the home of Psachos's dear friend Spyros Peristeris - and in Crete in 1911, in

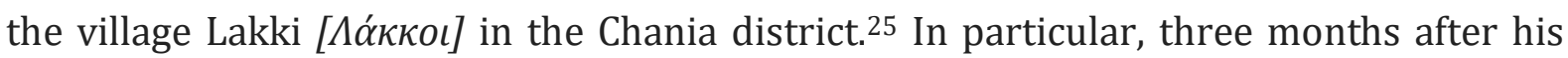
dismissal from the Athens Conservatoire, K. A. Psachos reclaimed the musical scores of these folk songs, alleging that he had intellectual rights to them. This started a judicial conflict which lasted from 1919 to 1921, ending in favor of Psachos. His intellectual rights to the musical dictations were eventually recognized, and their retrieval was granted, with a compensation, although, new trials for this matter, along with the subject of $\mathrm{K}$. A. Psachos's illegal dismissal from the Athens Conservatoire, started in 192226. These proceedings ended in 1925 with the intervention of the Friends of Greek Music Association, and it was then decided that the musical scores would be published (Athens Conservatoire Collection, 1930). Actually, K. A. Psachos seems to have had frequent contact with Konstantinos Kalamaras at that time, who was a member and representative of this Association and helped him with this matter ${ }^{27}$. Additionally, relevant evidence is present in the folder Athens Conservatoire of the K. A. Psachos's archive.

\footnotetext{
25 For the selection of the specific locations and for a detailed description of these expeditions and the controversy that followed between K. A. Psachos and the Athens Conservatoire, see Chaldæaki 2018b: 75 88; note that Psachos already had and afterwards continued to gain much experience documenting Greek folk songs in Byzantine and Staff Notation (records which he published in journals, such as Formigx), as also on relevant fieldwork (Psachos, 1910; 1923); new evidence regarding his musical dictations of Greek folk music see in Chaldæakes; Loupas; Chaldæaki, 2021.

${ }^{26}$ See an analytical documentation in Chaldæaki, 2018b: 82-88.

27 Konstantinos Kalamaras's name is mentioned in one of the Athens Conservatoire's Board Meeting Proceedings (see Chaldæaki, 2018b: 120); 78 letters of Kalamaras are found in K. A. Psachos's archive, dated between the years 1921-1926 and 1929-1932 (although in some of them the year is not specified),
} 
In addition, relevant to these matters are some epistles of K. A. Psachos's pen friend Christos Vlachos; ${ }^{28}$ here follow some examples:

I received today your epistle from the $22^{\text {nd }}$ of December, along with three short documents about the curriculum of your Conservatoire. I assure you that this information brought me much happiness for the achievement of your work, especially after your various struggles on it. Of course, difficulties will also exist in the future, but you have built a strong foundation. The beginning is half of everything, as you know, and I had better encourage you ${ }^{29}$.

I was delighted to know about the judicial decision for the matter between you and the Athens Conservatoire; everything that you will gain and profit will be in favor of our National music, for which you indefatigably labor ${ }^{30}$.

\section{Invigilator of music in the Churches of the Holy Church of Greece}

K. A. Psachos sought to be appointed as an invigilator at the Athenian churches as a means of enforcing the proper 'yphos' (performative style) of Byzantine Music and Psalmody according to the practice of the Patriarchate of Istanbul. This was a profession assigned to him in 1932 by the Minister of Education and Religion, Georgios Papandreou. The establishment of this post might have been something that $\mathrm{K}$. A. Psachos himself suggested, as evidenced below. In this role, K. A. Psachos was responsible for checking the skills of various church chanters and keeping a register with general and economic data about them. He then submitted relevant essays to the Ministry of Education and

and addressed from Athens and Patra; note that two of Kalamaras's letters refer to a dispute between Psachos and Melpo Logotheti-Merlier (that is briefly mentioned idid.: 34, note 55); this concerned a collection of Greek Folk Songs that Merlier wanted to create, with which she had asked Psachos to assist her.

${ }^{28}$ Christos Vlachos, who was a musician from Peloponnese and an enthusiast of the Greek musical tradition, as we can see from his regular publications in the newspaper Formigx [Фó $\mu \iota \gamma \xi]$, wrote frequently to K. A. Psachos about various matters; 17 of his letters are included in the archive, dated between the years 19181920, 1922, 1928-1929, 1935, 1938, 1942 and addressed from Zatouna, Zourtsa, Trikala, Karitæna and Rododafni of Peloponnese, Megara and Kythnos.

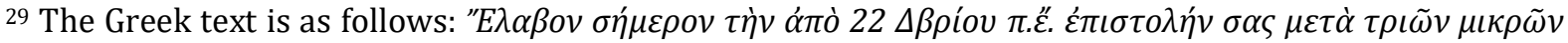

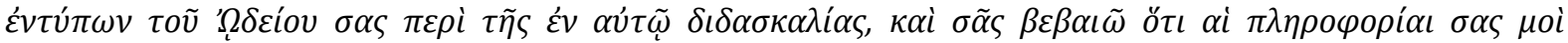

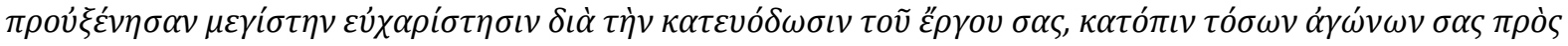

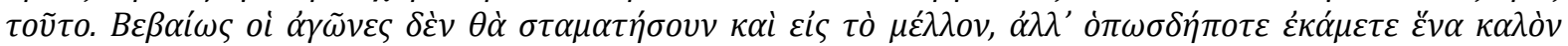

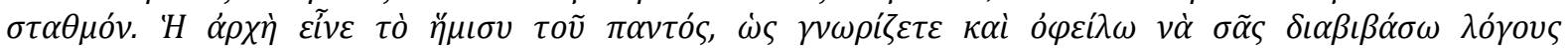

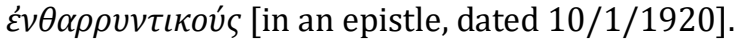

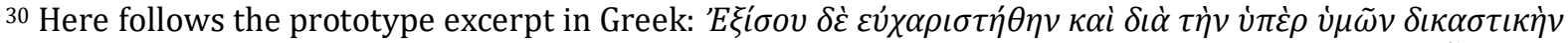

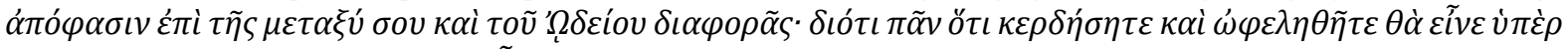

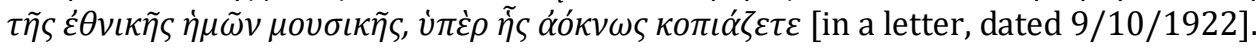


Religion. We don't know exactly how long K. A. Psachos was occupied in this specific position, since, reputedly, it gradually dissipated.

K. A. Psachos seems to have corresponded regarding this matter with Konstantinos Kalamaras, who helped him to be assigned to this position, as indicated by the following:

I rush to casually inform you that today the Board of the Insurance Treasury of Greece's Cleric, as Mr. Lontos told me, authorized your designation [...] All that remains is for the official order to be published, which the Minister will shortly do. I congratulate you and I wish you full gratification ${ }^{31}$.

I was informed by Mr. Lontos that your designation was signed and it is expected to be published ${ }^{32}$.

Mr. Lontos informed me that in order for your designation to be published, the Decree of your responsibilities should also be issued at the same time. This way, you and the Ministry will know exactly what you will be assigned to do. Although, because no one here is acquainted with your duties, I must ask you to give your plan and share your thoughts without delay, in coordination with Mr. Filippides and the Metropolitan, so that the new Decree can be prepared immediately and both of them will then be published ${ }^{33}$.

Pertinent to this subject are also some writings of Dimitrios Peristeris, another of K. A. Psachos's frequent pen friends; ${ }^{34}$ for instance:

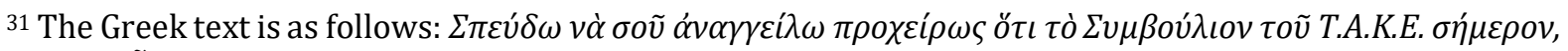

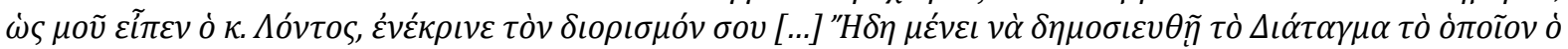

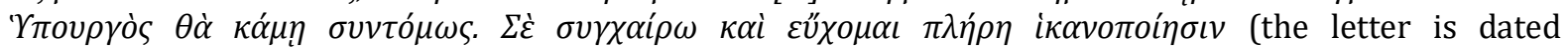
$17 / 12 /[1931])$.

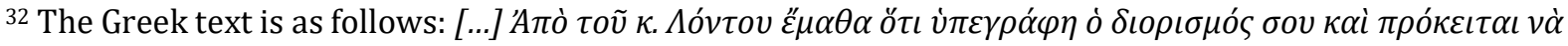
$\delta \eta \mu о \sigma \iota \varepsilon v \theta \tilde{\eta}$ [in a letter, dated 3/1/1931].

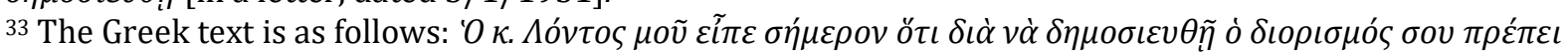

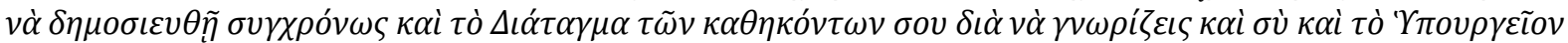

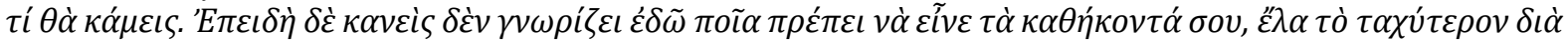

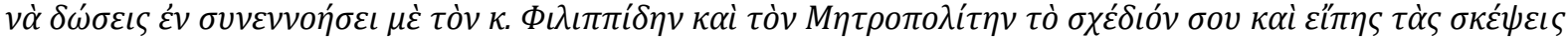

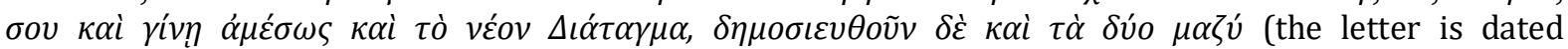
$19 / 1 /[1932])$.

${ }^{34}$ For the record, 14 letters from Dimitrios Peristeris are found in the correspondence folder, dated from the years 1926, 1928-1930, 1933, 1935 and sent from his residence in Mourla; two more epistles of Peristeris, dated 1913 and 1942, were found in folders related to folk music, as these concluded musical records; also, in the same envelope, some letters from extended members of Dimitrios Peristeris's family were tracked down; specifically, 14 from Peristeris's daughter Sofia Peristeri, 1 from his son Spyros Peristeris and 4 from his wife Theoni Stamatopoulou. K. A. Psachos seemed to have a special appreciation for Dimitrios Peristeris's family; according to a letter from Sofia Peristeri dated 21/8/1928 and one from Dimitrios Peristeris with the same date, after the death of his wife Evanthia, Psachos sent Sofia some of her jewelry.
} 
I would like to know what duties you took over after your designation: What happened with your memorandum? Did you get an answer about it? Are you receiving your salary? I am specifically interested in this, to assure that you are not distressed 35 .

\section{Munich (Socrates Loupas)}

K. A. Psachos's presence and activity in Munich $(1922-1924,1926)$ is connected with the

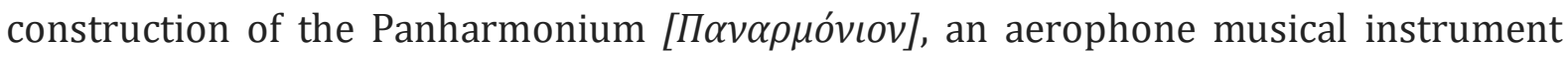
with two keyboards, a pedal and pipes, in the form of West European pipe organs; K. A. Psachos designed it to accurately perform the musical scales of Byzantine and Greek folk music (Chaldæaki, 2018b: 48-50; Romanou, 2016; Apostolopoulos, 2016; 2015; Makris, 2013; Paraschos, 2013; Mamoni, 2000: 97). The idea of making a musical instrument which would be useful for studying and teaching Byzantine Music was not new. In 1881 and in 1898, similar attempts were made in Istanbul by committees appointed by the Ecumenical Patriarchs Joachim III (1834-1912) and Constantine V (1833-1914) (Romanou, 2016). Those keyboard instruments proved to be too difficult to use and strenuous, mainly because of their large number of keys and finally they were abandoned (Romanou, 2016). In 1903, Georgios Nazos (1862-1934), the director of the Athens Conservatoire, visited the Patriarchate of Istanbul looking for information, ideas and the right person to direct and teach at the new School of Byzantine and Ecclesiastical Music which was about to open at the Conservatoire (Chaldæaki, 2018b: 55-57; Hadzitheodorou, 1978: $\left.\kappa \varepsilon^{\prime}[25]-\kappa \sigma \tau^{\prime}[26]\right) ;$ G. Nazos met with the members of the Ecclesiastical Music Association of Constantinople and he talked about three things: a) the need for teaching Byzantine Music on a fixed tonal system, b) the need for using a musical instrument for the proper and uniform performance of the intervals, and c) the need for precise and correct reading of Byzantine Notation (Romanou, 1996: 97-104).

When K. A. Psachos arrived in Athens (1904), he dedicated all his powers to organizing the School of Byzantine Music. With his lectures, publications and concerts he vigorously reacted against an already established and growing situation: the Westernization of Byzantine Ecclesiastical Music and Greek folk songs and the introduction of the piano and the tetraphonic music in the Greek Orthodox Churches, especially those in the center of

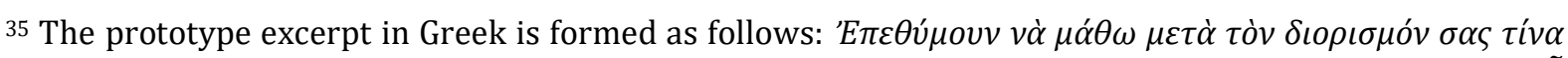

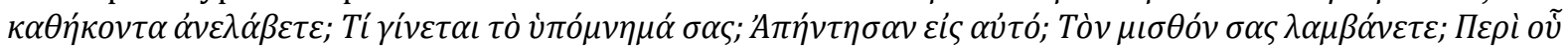

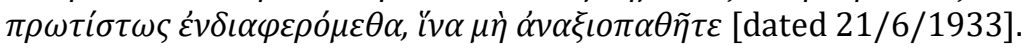


Athens (Hadzitheodorou, 1978: $\kappa \delta^{\prime}[24]-\kappa \varepsilon^{\prime}[25]$; Romanou, 1996: 31-95). We don't know when exactly he started planning the construction of an instrument, but it must have been in his mind since he came to Athens. It proved to have been an ambitious project which required a collaboration of experts, years of research, a pipe organ building factory and above all funds to finance the construction.

The project of constructing the instrument was officially announced in 1921 when K. A. Psachos together with Stavros Vrahamis (1880-1950), a physicomathematician and musicologist, began their regular meetings ${ }^{36}$. Eva Palmer-Sikelianos (1874-1952), an American choreographer and scholar of ancient Greek culture, wife of the prominent Greek poet Angelos Sikelianos (1884-1951), provided financial and administrative support to the expensive and time-consuming project ${ }^{37}$. In 1922, K. A. Psachos made his first trip to Oettingen, a town in Bavaria, $150 \mathrm{~km}$ away from Munich, where the pipe organ building factory G. F. Steinmeyer \& Co. (founded in 1847) was based (Hadzitheodorou, 1978: $\lambda \delta^{\prime}[34]-\lambda \sigma \tau^{\prime}[36]$; Chaldæaki, 2018b: 49-50), to supervise the construction progress. In 1923 he probably travelled again and in early 1924 he made his third trip and stayed until the construction's completion in June of the same year.

\section{The Archive}

In his personal archive, which K. A. Psachos kept at his residence carefully arranged in folders according to his many fields of work ${ }^{38}$, we find the folder Instrument (or Organ)

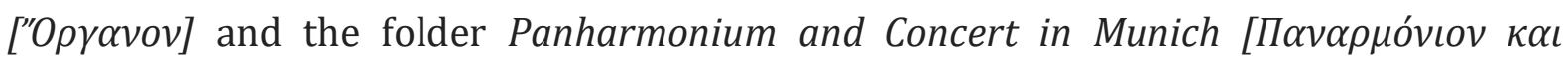

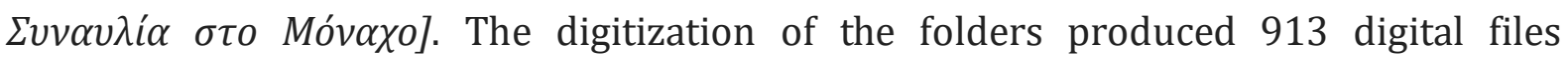
containing various types of material: Greek, German, French and Italian newspaper clippings and magazines, letters from the Steinmeyer Company and from people who

\footnotetext{
${ }^{36}$ The news was published serially in K. A. Psachos's musicological newspaper New Formigx (NÉ $\alpha$ Фó $\left.\rho \iota \gamma \xi\right)$; see Chaldæaki, 2018b: 49-50. Professor of Philology at the University of Athens Emmanuel Pezopoulos (1880-1947) accompanied K. A. Psachos in his first trip to Oettingen and S. Vrahamis in his second.

${ }^{37}$ Eva Palmer-Sikelianos was a Byzantine Music student of K. A. Psachos. Since their meeting in 1908 they developed a relationship of student and teacher. E. Palmer-Sikelianos helped K. A. Psachos in his research and effort to record Greek folk songs by contacting - through her brother - Thomas Edison and receiving wax cylinders for K. A. Psachos's phonograph. She had arrived in Greece only a year earlier (1907). Passionate about ancient Greek and Byzantine culture, she had already thrown away her western clothes and replaced them with ancient Greek-style clothes which she designed and weaved herself. E. PalmerSikelianos also shared K. A. Psachos's vision to defend the integrity of Byzantine chants against Westernization. For her life and work, see Leontis, 2019.

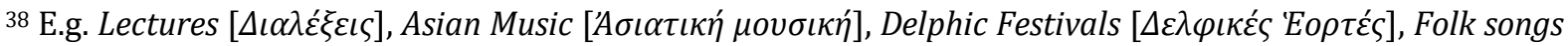

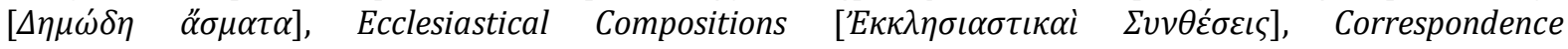

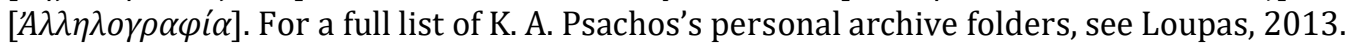


contributed to the project, telegrams, photographs, contracts and K. A. Psachos's handwritten notes. This material constitutes the story of a unique instrument in the musical history of modern Greece.

What we could tell in short about the folders' contents is: all the documents are dated between the years 1922-1924; only some documents are dated in 1926, which is the year when K. A. Psachos visited Munich to give a concert of ancient, Byzantine and Greek folk music; there are no documents dated before 1922, e.g. about the meetings between K. A. Psachos, St. Vrahamis, E. Palmer-Sikelianos and others; also, there are no important documents after 1924 that could help us understand better why the Panharmonium remained in Germany and was never brought to Greece, as it will be mentioned below. E. Palmer-Sikelianos did not only fund the construction which cost more than 3,000 dollars $^{39}$; she also mobilized her network of people in Germany and Greece and she planned the transportation of the instruments to Greece ${ }^{40}$. Greek painter Umvertos Argyros (1884-1963) was a friend of K. A. Psachos who studied and lived in Munich and facilitated the communication between the latter and Steinmeyer Company; U. Argyros would translate most of the correspondence between them (K. A. Psachos was not fluent in German). He became their interpreter in the meetings and also hosted K. A. Psachos at his house in Munich.

It seems that the correspondence between the inventor and the Company was challenging. Given the delay of postal communication it must have been difficult for both sides to synchronize their work. The factory was working for the first time on a unique keyboard and pipe instrument and had to ask K. A. Psachos about everything ${ }^{41}$. In 1923 K. A. Psachos was probably planning to add a $5^{\text {th }}$ octave to the Panharmonium and/or a

\footnotetext{
39 The amount was paid in installments. In a letter dated on $27^{\text {th }}$ of November 1923, the Steinmeyer Company informed K. A. Psachos that the cost up to that point was 2,840 dollars. The Company was kindly asking for the payments to be in dollars at the earliest opportunity because, since the beginning of the construction, the cost of salaries and raw materials had dramatically changed due to the high inflation in Germany at that time. The money usually was transferred from E. Palmer-Sikelianos's City Bank account in New York to the Company's account at Deutsche Bank in Munich.

${ }^{40}$ In a letter dated on $20^{\text {th }}$ of September 1924, E. Palmer-Sikelianos informed K. A. Psachos that "the Harmonium has been finally sent" (she means the small one) and that she already contacted a friend, Takis Papatsonis (probably the Greek poet Takis Papatsonis, 1895-1976), who was then an employee at the Greek customs office and he was willing to help with the paperwork; cf. Chaldæaki, 2019: 131, note 41.

${ }^{41} \mathrm{~A}$ number of letters contain information or questions addressed to K. A. Psachos: e.g. the purchase of 100 $\mathrm{kg}$ of tin for the construction of the pipes (letter on 29-6-1923) and questions like whether the wooden parts should be made of spruce or oak (letter on 8-11-1923).
} 
clarinet $^{42}$. In the draft contracts we read that K. A. Psachos was the exclusive orderer and owner of the Panharmonium; he is recognized as the inventor and possessor of the patent but he is obliged to an exclusive cooperation with Steinmeyer Company for future orders for more Organs and Harmoniums; the company cannot make a copy of the Panharmonium without the inventor's approval; Psachos is jointly responsible for the final result and in case of a failure all the expenses must be covered. We find no prediction of what would happen in case of a repair or correction of the musical instruments.

\section{The inauguration of the Panharmonium}

Finally, three instruments were made: one big organ, 3,40m high with 660 pipes, 4 octaves and 165 keys (42 to an octave), which was called the Panharmonium and two smaller Harmoniums, one with 4 octaves and one with 2. The Panharmonium and the 4octave Harmonium had two keyboards, the first one with the keys of a European piano and a second with the keys for playing Byzantine music. An automatic pianola (selfplaying piano with scrolls), which worked with electric power, was also presented. It was made at the Concordia Notenrollen Fabrik Grieshaber \& Co. in Leipzig and could be connected to the Panharmonium. The Panharmonium was named Evion Panharmonium in honour of Eva Palmer-Sikelianos and the inauguration took place at the factory in Oettingen on the $29^{\text {th }}$ of June 1924 [figs. 1-4].

K. A. Psachos collected in his archive newspaper clippings and magazines with the news about the invention and the inauguration day. The list is large ${ }^{43}$. The selected day was a Sunday and a large crowd gathered with members of the Greek community in Munich and many Germans attending the event. Eminent guests appeared as well: the historian and philologist Ludwig Bürchner (1858-1927), the professor of Byzantinology at the University of Munich August Heisenberg (1869-1930), the Consul General of the Greek

\footnotetext{
${ }^{42}$ Both requests were rejected by the Company and K. A. Psachos was strongly advised to avoid a possibly unpredictable outcome (letters on 23-11 and 10-12-1923).

${ }^{43}$ Some of the publications that K. A. Psachos saved in the folder are the following: Filotechnos, 1924;

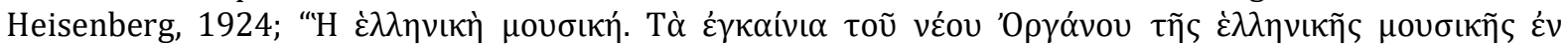

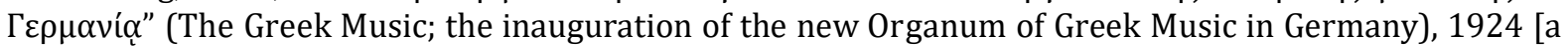

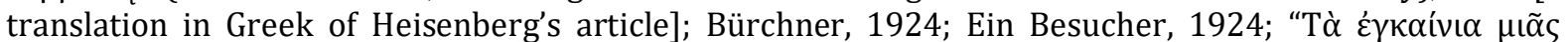

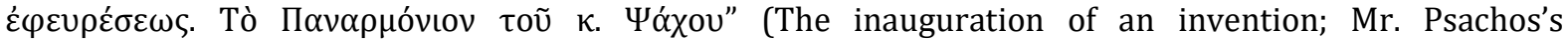
Panharmonium], 1924 [a translation in Greek of the article published in German under the pen name Ein Besucher]; Psachos, 1924a; Hoesslin, 1925.
} 
Consulate in Munich Ernst von Basserman-Jordan (1876-1932), and a classical soprano from India, Khurshedben Naoroji (1894-1966) ${ }^{44}$.

In the collected newspapers and magazines, we also read about the program of the day; K. A. Psachos made a speech in Greek about the history of Byzantine Music. He disclosed that he had been working on the making of the Panharmonium for thirty years and he explained his theory that European musical instruments could not play Byzantine Music. He also thanked E. Palmer-Sikelianos, U. Argyros and physicomathematician Spyridon Malakates (1885-1950) for their help45. Then Professor Heisenberg read Psachos's speech in a German translation. The musical program began with the automatic pianola playing Greek folk songs and Byzantine Music. Then, E. Palmer-Sikelianos sat before the Panharmonium and played Byzantine Music. K. Naoroji was invited to play and everyone was surprised to see that she could easily play Indian and Byzantine Music as well. E. Palmer-Sikelianos played again Byzantine Music pieces and Greek folk songs. The crowd was enthusiastic and the program ended in applause. K. A. Psachos was crowned with a laurel wreath and E. Palmer-Sikelianos was offered flowers. The eminent guests along with all the contributors were invited to Steinmeyer's house for lunch. There is a striking detail in all the articles and Press reports on the inauguration: K. A. Psachos is not mentioned to have played the Panharmonium. The group went back to the factory in the afternoon and they played again but there is no mention of who performed.

\section{The fate of the Panharmonium}

The two Harmoniums arrived in Greece a few weeks after the inauguration ${ }^{46}$, but the Panharmonium remained at the Steinmeyer factory. The factory sent a letter to K. A. Psachos on 19th of August 1924, informing him that professors from the University of Hamburg were interested to see it. There are no records in Psachos's archive about any activities of bringing the Panharmonium to Greece. We know that Psachos wanted to find a space with the ideal acoustics to place it and that his vision was to introduce the

\footnotetext{
${ }^{44}$ E. Palmer-Sikelianos invited Khurshedben Naoroji to Oettingen after they met in Paris and became friends; see Leontis, 2019: 126-136; Naoroji later met with Mahatma Gandhi and joined his movement of nonviolence; for the remarkable life of Naoroji (see Patel, 2021).

${ }^{45}$ When K. A. Psachos returned to Greece he published his speech; see Psachos, 1924b.

${ }^{46}$ Particularly, the two smaller instruments were sent to Greece in August 1924 (Letter of U. Argyros to K. A. Psachos on $1^{\text {st }}$ September 1924). One was transferred to the house of E. Palmer-Sikelianos and the other to K. A. Psachos's house. For further information about these two organs and their current place, see Chaldæaki, 2019: 130-133.
} 
Panharmonium in Byzantine musical education ${ }^{47}$. In 1926 he went to Munich again and gave a concert [facs. 17-19]. We don't know if he visited the Panharmonium (he must have) and if he tried to send it to Greece. After 1924 the Sikelianos couple started focusing on the organizing of the Delphic Festivals $(1927,1930)$. K. A. Psachos was invited to compose the music for the ancient dramas, but after the Delphic Festivals the relationship between K. A. Psachos and E. Palmer-Sikelianos fell apart. Also, her marriage with Angelos Sikelianos didn't go well, and after she had spent all her money on the Delphic Festivals she returned to the USA in 1933. She came to Greece again in 1952, only a few weeks before she died.

In 1938 K. A. Psachos translated into Greek the contract he signed with the Steinmeyer Company and he had the translation validated by a Greek lawyer. The contract is rather brief; it summarizes what we already know from the draft contracts [facs. 20-22]. It is signed by G. F. Steinmeyer, K. A. Psachos and E. Palmer-Sikelianos, but only K. A. Psachos is mentioned in the terms. K. A. Psachos died in 1949 and the case of the Panharmonium was forgotten. In the later years it was considered lost. In 2012 the present author contacted the Steinmeyer Company and confirmed that the Panharmonium was still there, disassembled and stored. In October 2016 the Department of Music Studies of the School of Philosophy of the National and Kapodistrian University of Athens organized a Byzantine Musicological Conference and a Concert dedicated to the Panharmonium ${ }^{48}$.

47 In an undated draft note, under the title Conciliation plan with the Athens Conservatoire [ $\Sigma \chi \varepsilon$ Éov

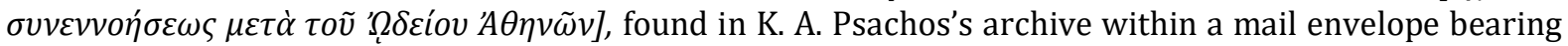

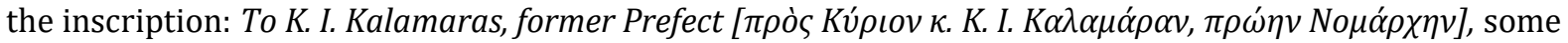
thoughts regarding K. A. Psachos's concern of the Panharmonium are found. Konstantinos Kalamaras drafted a plan (probably in consultation with K. A. Psachos) to resolve the aforementioned conflict between K. A. Psachos and the Athens Conservatoire. The plan was included a term referring to the Panharmonium: ...The Conservatoire is required to house the Evion Panharmonium at its premises, providing its regular custody, as it is custom for its own musical instruments. For that, the Conservatoire will receive the right to use the Panharmonium whenever there is need [...] The Conservatoire takes no other responsibility regarding the Evion while the Association [sc. the Friends of Greek Music Association (represented by the mentioned Konstantinos Kalamaras)] is required to ensure the Panharmonium on the Association's behalf... [Tò

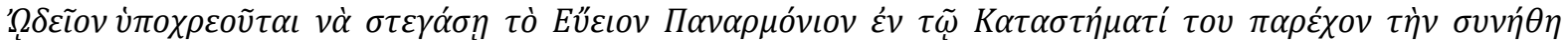

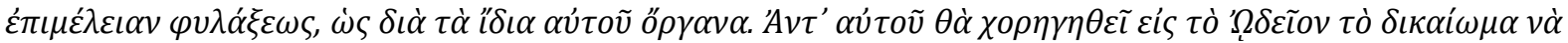

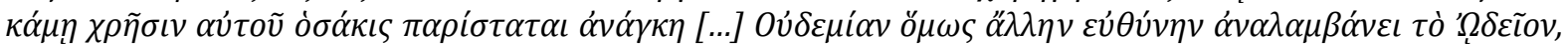

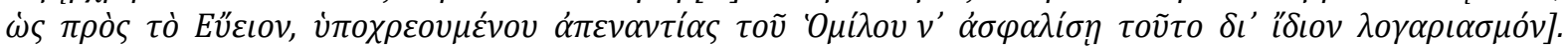
Nevertheless, it isn't known if this plan was ever officially proposed.

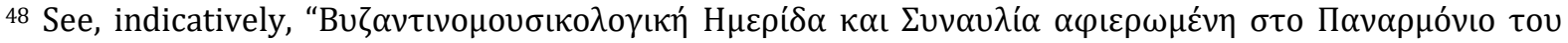

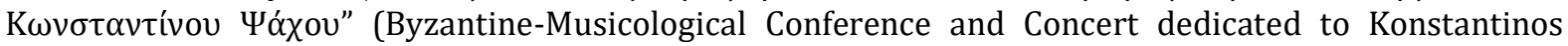
Psachos's Panharmonium), 2016. 
Professor Achilleas Chaldæakes informed the Conference that the Panharmonium passed to a private collection and announced his attempt to bring it to Greece.

\section{Conclusion}

During his life and work in Athens K. A. Psachos established a network of collaborators, students and friends. He succeded in strengthening the continuity of Byzantine musical tradition in Greece and left a signifant amount of work in the field of Greek folk music and Asian music studies in Greece. His educational and intellectual background, established in the first years of his life that he spent in Istanbul and documented in his Student Notes, proved to be most suitable for the demanding position that he first occupied in Athens, - the organization and direction of the School of Byzantine Music at the Athens Conservatoire-, as well as for his other occupations and achievements. K. A. Psachos had a vigorous and active character and never hesitated to defend his ideas and combat misjudgment. He also managed to realize an ambitious vision: he designed and constructed an organ to accurately perform Byzantine and Greek folk Music.

Although K. A. Psachos's musicological work is well studied, especially in connection with the field of Byzantine Musicology, his archive remains mostly unknown, unrecorded, and underutilized by the international academic community. The wide range of his interests and professional activities cannot be presented in one paper. By presenting some historico-musicological aspects of this archive, we hope that future researchers will clearly realize its crucial importance and critical significance; we also hope, finally, that the planned publication of K. A. Psachos's oeuvre, a grandiose project of international academic caliber, will be decisively promoted.

\section{REFERANCES}

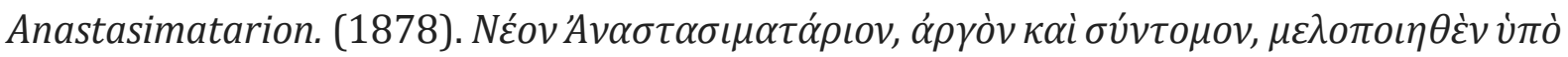

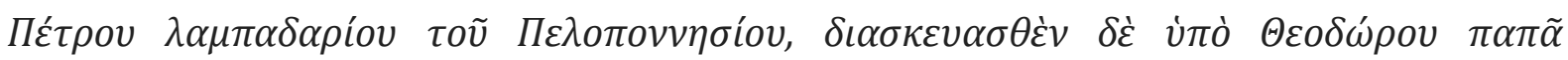

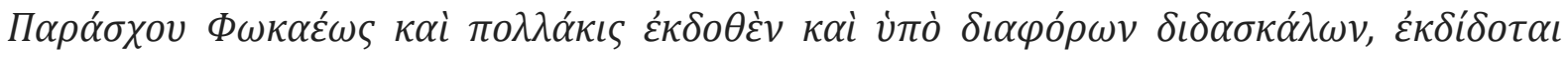

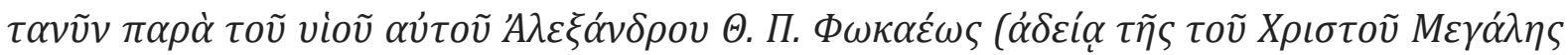

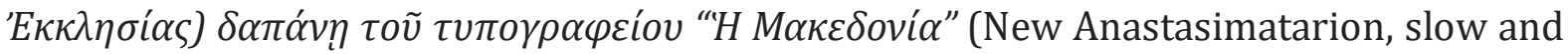


short, composed by Peter the Peloponnesian). Thessaloniki: Stefan Thanos \& Spyridon Vasileiadis Publications.

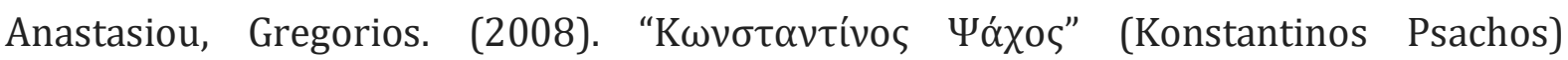

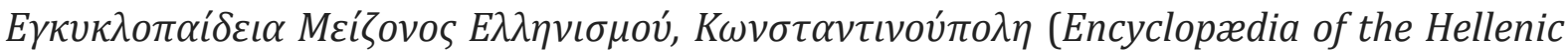
World, Constantinople). Retrieved from http://www.ehw.gr/l.aspx?id=11060 [accessed 31 July 2021].

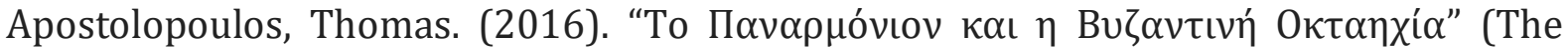
Panharmonium and the Byzantine Octaechia). [Video file]. Retrieved from https://www.pemptousia.gr/video/ta-panarmonion-ke-i-vizantini-oktaichia/ [accessed 31 July 2021].

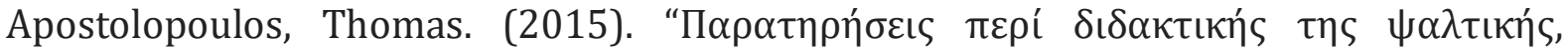

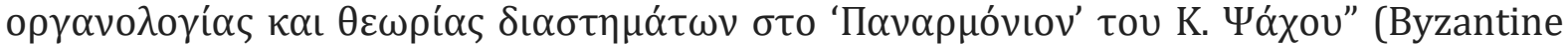
Music Teaching, Organology and Interval Theory using Konstantinos Psachos's

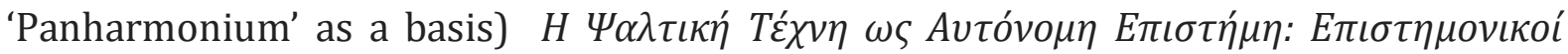

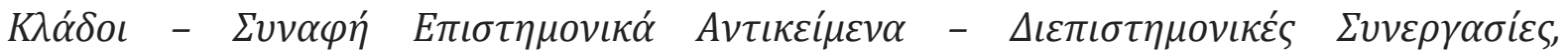

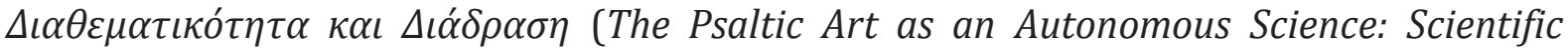
branches - Related scientific fields - Interdisciplinary Collaborations and Interaction, The $1^{\text {st }}$ International Interdisciplinary Musicological Conference) Konstantinos Karagounis; George Kouroupetroglou (Eds.), (pp. 110-123). Retrieved from https://speech.di.uoa.gr/IMC2014/pdffull/112-125.pdf [accessed 31 July 2021].

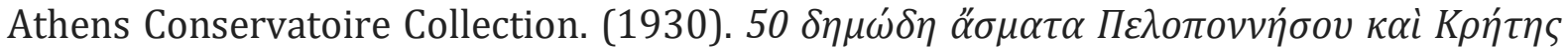
(50 Folk Songs from Peloponnese and Crete). Athens: Sideris Editions.

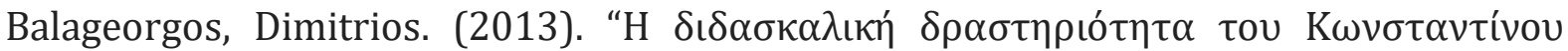

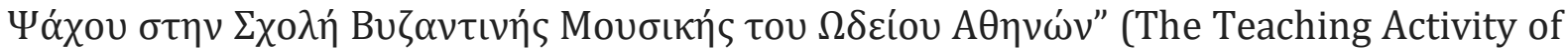
Konstantinos Psachos in the School of Byzantine Music at the Athens Conservatoire)

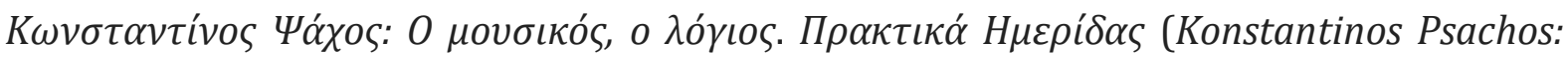
The Musician, the Scholar. Conference Proceedings), (pp. 79-100). Athens: Publications of the Academy of Athens. 
Bürchner, Ludwig. (1924). "Die Orgel Prof. Psachos für byzantinische und anatolische Musik" (Konstantinos Psachos's Organ for Byzantine and Eastern Music) Neue MusikZeitung. 2: 304-305.

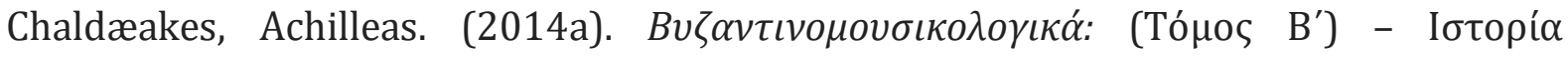
(Byzantine-Musicological: 2 ${ }^{\text {nd }}$ volume: History). Athens: Athos Editions.

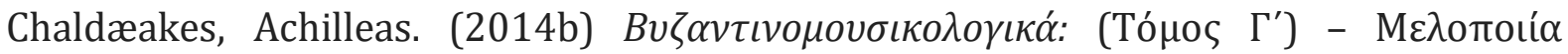
(Byzantine-Musicological: $3^{\text {rd }}$ volume: Melopoeia). Athens: Athos Editions.

Chaldæakes, Achilleas; Loupas, Socrates; Chaldæaki, Evangelia (2021). "Uses of the New Method of the Byzantine Notation; Historico-musicological Testimonies from K. A. Psachos's Archive" Epistêmês Metron Logos. 6: 1-47.

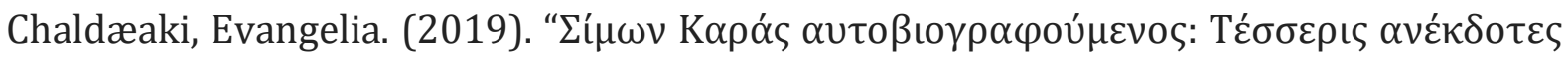

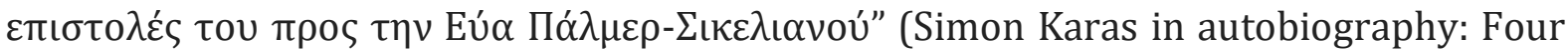
unpublished letters to Eva Palmer-Sikelianos). [Paper presented at the $11^{\text {th }}$ Interfaculty Musicological Congress of the Hellenic Musicological Society, 21-23 November 2019 Athens, Greece: "Innovation and tradition"] Foulias, Ioannis; Kardamis, Kostas; Sakallieros, George (Eds.), (pp. 123-151). Retrieved from https://hellenicmusicology.org/wp-content/uploads/2020/11/ConfProc2019.pdf [accessed 31 July 2021].

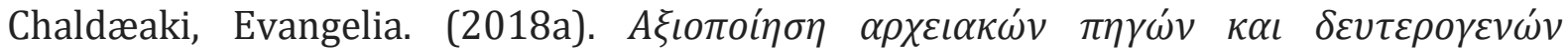

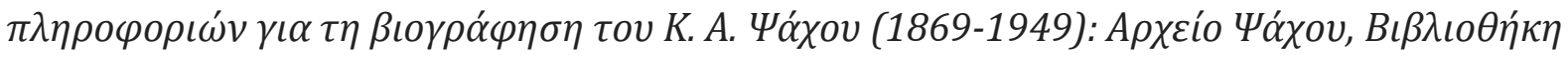

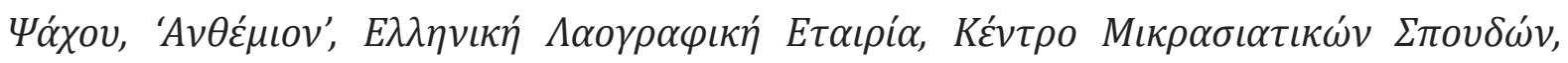

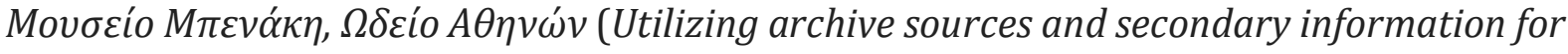
making the biography of Konstantinos Psachos (1869-1949); Psachos's Archive \& Library, 'Anthemion', Greek Folklore Society, Centre of Asia Minor Studies, Benaki Museum, Athens Conservatoire). Paper presented at the $2^{\text {nd }}$ Congress of the Greek Department of the International Association of Music Libraries, Archives and Documentation Centers, Athens Conservatory, Greece, 27-28 April 2018.

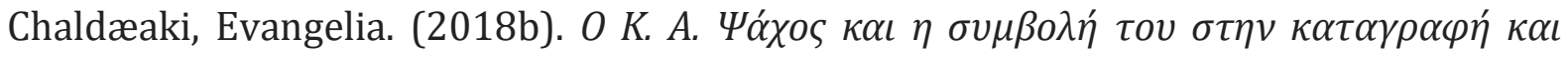
$\mu \varepsilon \lambda \varepsilon ́ \tau \eta \varepsilon \lambda \lambda \eta v \iota \kappa \omega ́ v ~ \delta \eta \mu о \tau \iota \kappa \omega ́ v ~ \tau \rho \alpha \gamma o v \delta \iota \omega ́ v$ (Konstantinos Psachos and his contribution to 
recording and studying Greek Folk Songs). Athens: Publications of Athens ConservatoireEdition Orpheus.

Dragoumis, Markos. (1990). “Konstantinos A. Psachos (1869-1949); A Contribution to the Study of his Life and Work" Studies in Eastern Chant. 5: 77-88.

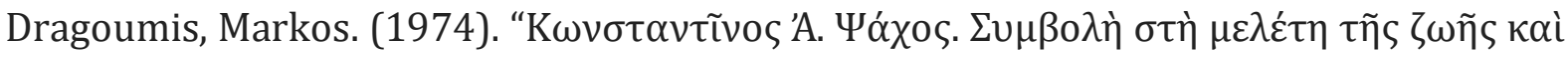

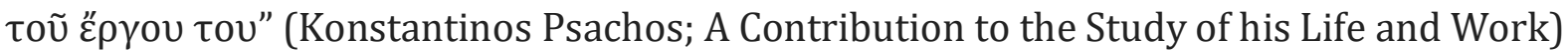

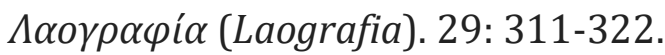

Ein, Besucher. (1924, September 20). "Einweihung der Byzantinischen Orgel bei der Firma G. F. Steinmeyer \& Co." (Inauguration of the Byzantine Organ at G. F. Steinmeyer \& Co.) Oettinger Anzeiger, p. 2.

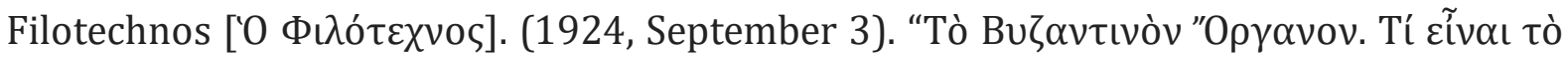

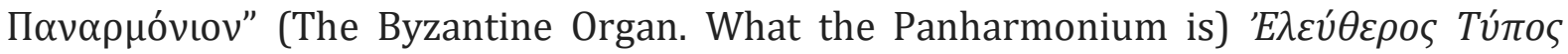
(Eleftheros Typos), pp. 1-2.

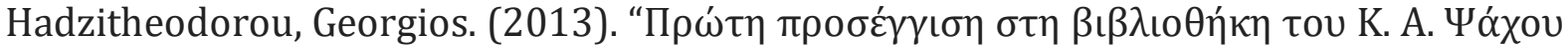

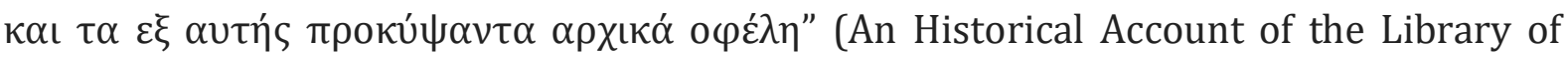

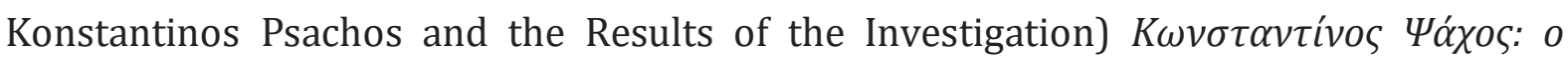

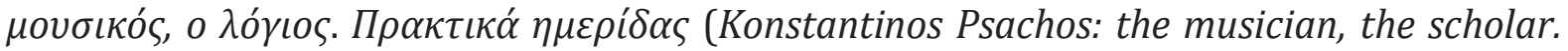
Conference Proceedings), (pp. 217-250). Athens: Publications of the Academy of Athens.

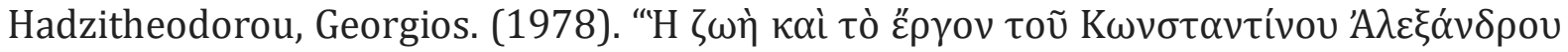

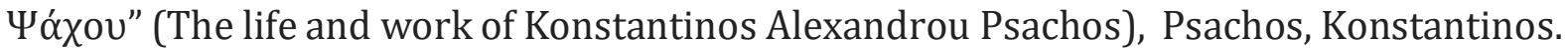

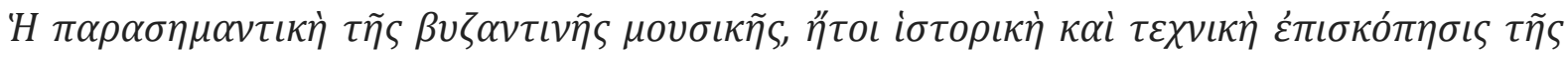

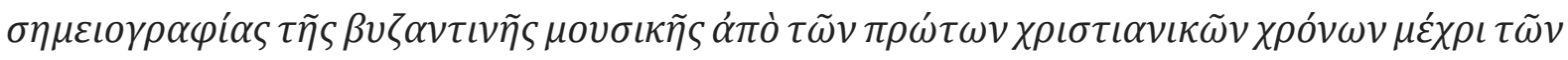
$\kappa \alpha \theta^{\prime} \dot{\eta} \mu \tilde{\omega} \nu$ (The Parasimantiki of the Byzantine Music; a Historical and Technical Review of the Notation of the Byzantine Music from the first Christianity years until nowadays). (2nd edition). Athens: Dionysos Publishing Co.

Heisenberg, August. (1924). "Eine neue Orgel für byzantinische Musik" (A new Organ for Byzantine Music) München-Augsburger Abendzeitung, p. 2. 
Hoesslin, v. K. J. (1925), "Eine neue Orgel für Byzantinische Music" (A new Organ for Byzantine Music) Die Musik. 4: 278-280.

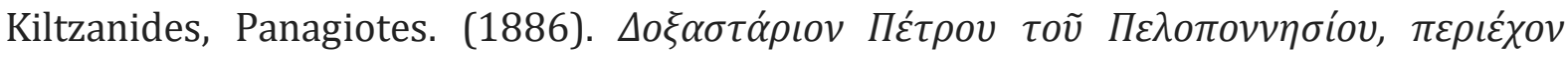

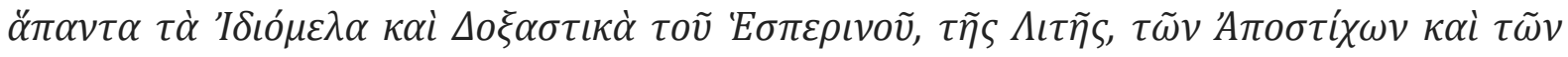

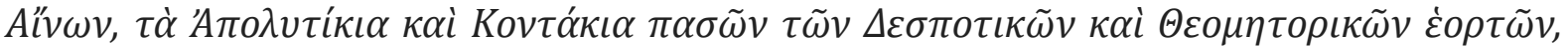

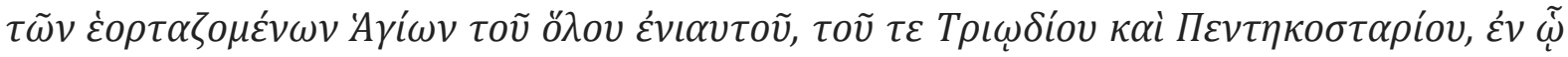

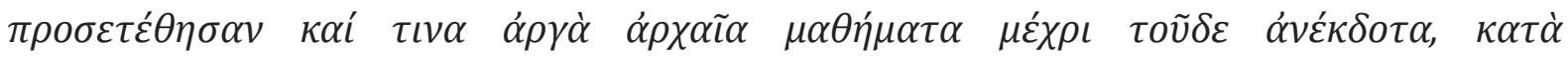

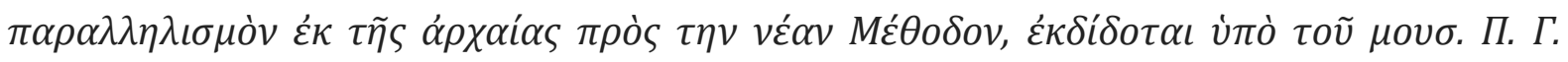

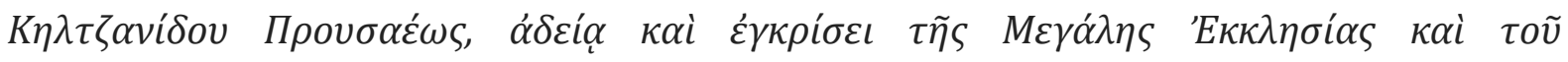

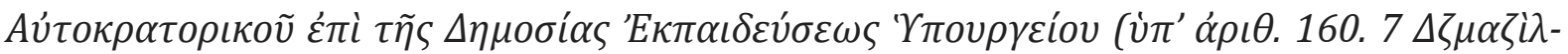

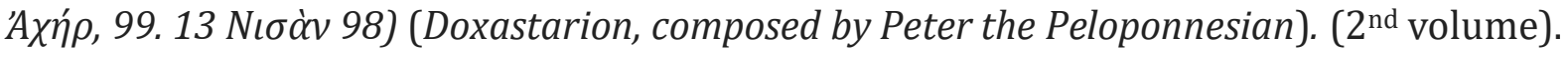
Constantinople.

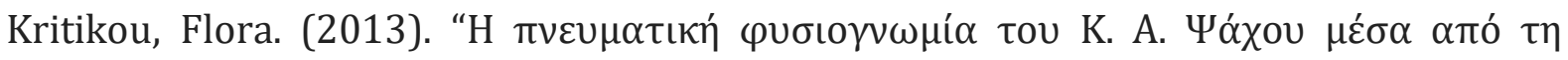

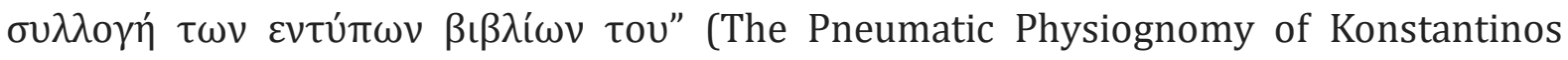

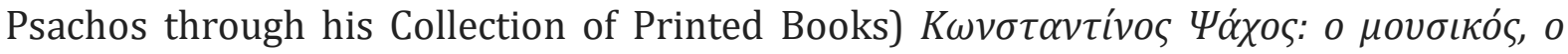

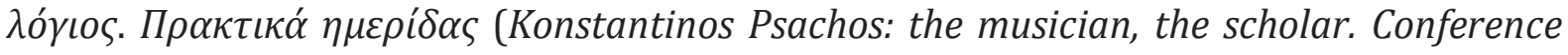
Proceedings), (pp. 57-68). Athens: Publications of the Academy of Athens.

Leontis, Artemis. (2019). Eva Palmer Sikelianos. A Life in Ruins. New Jersey: Princeton University Press.

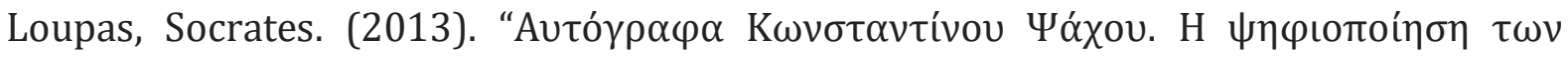

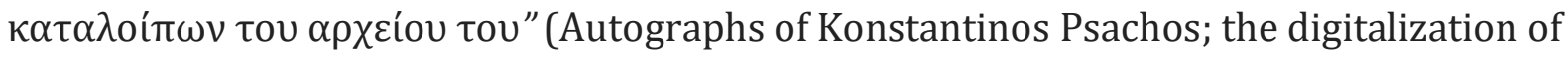

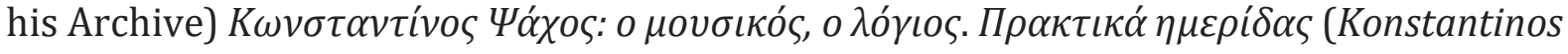
Psachos: the musician, the scholar. Conference Proceedings), (pp. 315-325). Athens: Publications of the Academy of Athens.

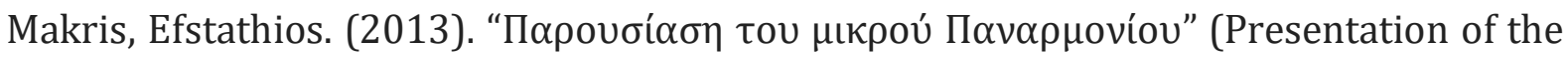

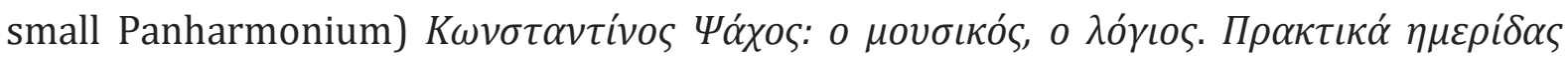
(Konstantinos Psachos: the musician, the scholar. Conference Proceedings), (pp. 297-304). Athens: Publications of the Academy of Athens. 


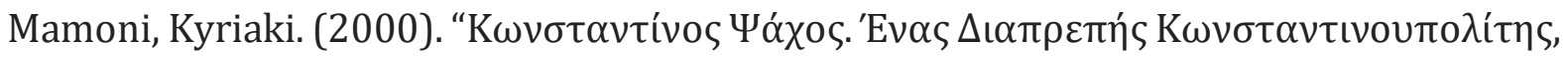

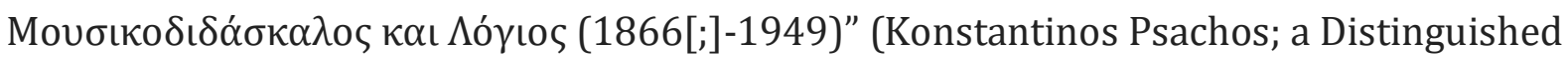

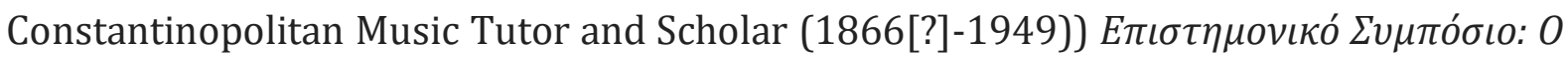

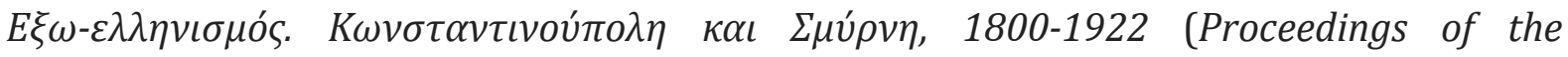
Conference: The Outside Hellenism; Istanbul and Smyrna, 1800-1922) Stefanopoulou, Maria (Ed.), (pp. 89-104). Athens: Publications of the Society of Modern Greek Cultural Studies-Moraitis's School.

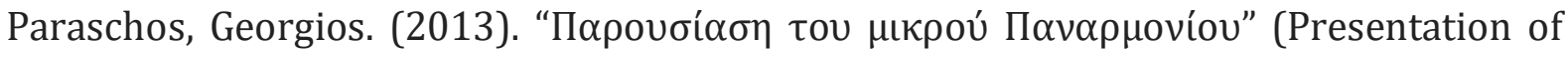

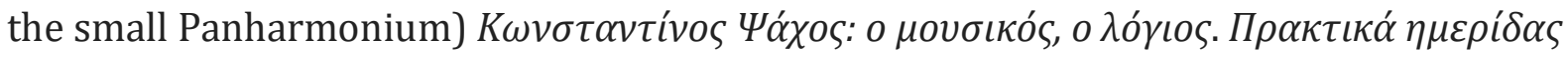
(Konstantinos Psachos: the musician, the scholar. Conference Proceedings), (pp. 305-313). Athens: Publications of the Academy of Athens.

Patel, Dinyar. (2021, June 27). "Kurshedben Naoroji: The singer who preached nonviolence to bandits". BBC News. Retrieved from https://www.bbc.com/news/worldasia-india-57523456 [accessed 31 July 2021].

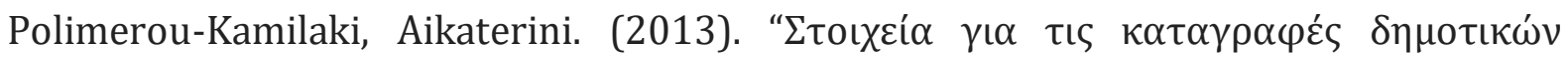

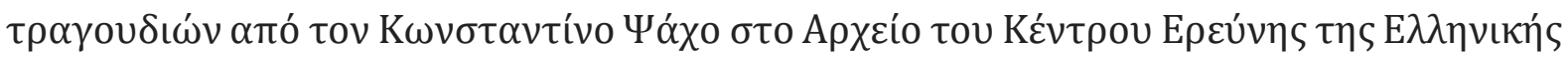
$\Lambda \alpha о \gamma \rho \alpha \varphi$ í $\varsigma^{\prime \prime}$ (Elements for the Records of Folk Songs by Konstantinos Psachos in the

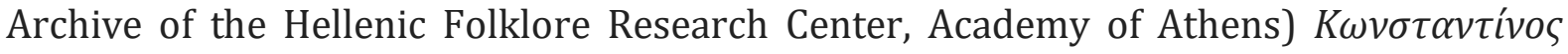

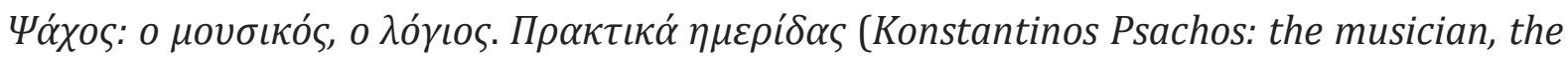
scholar. Conference Proceedings), (pp. 11-27). Athens: Publications of the Academy of Athens.

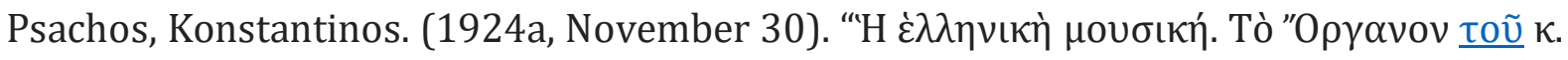

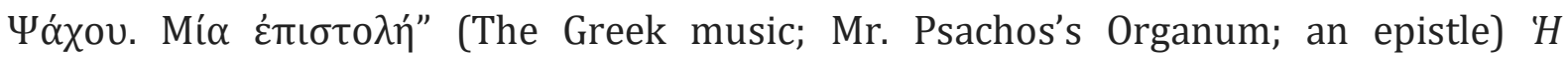

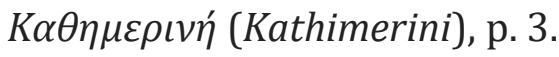

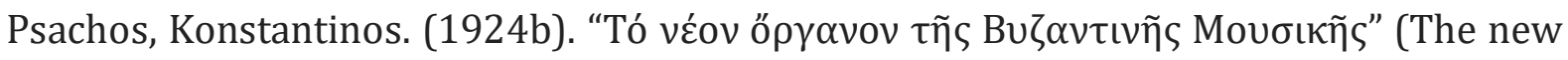

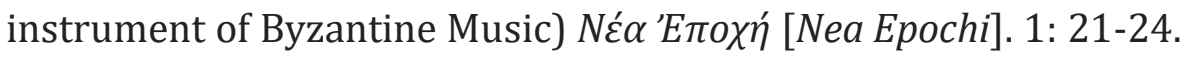

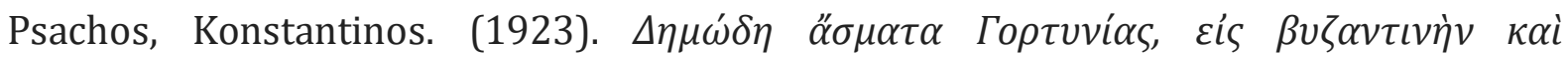

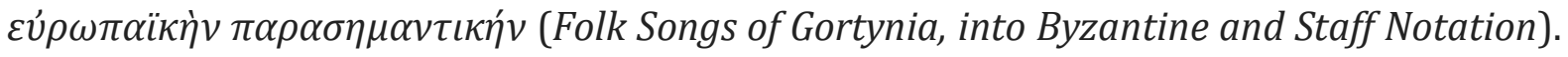
Athens. 


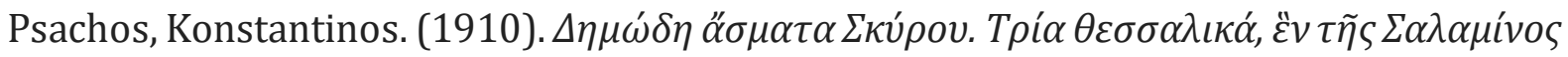

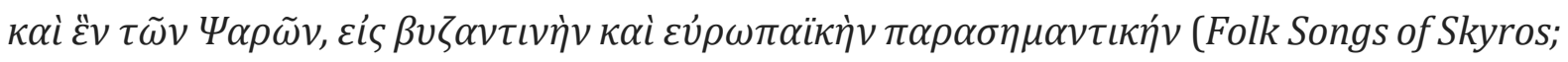
three from Thessaly, one from Salamis, and one from Psara; into Byzantine and Staff Notation). Athens: Sp. Kousoulinos Printshop.

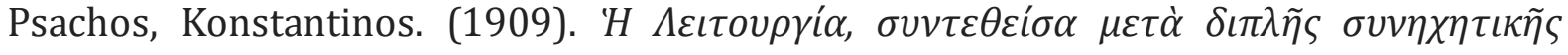

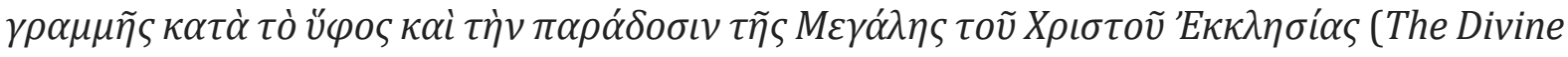
Liturgy, composed with double consonance line, according to the performative style and the tradition of the Great Church of Christ). Athens: Sp. Kousoulinos Printshop.

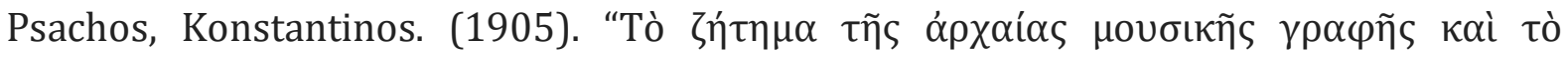

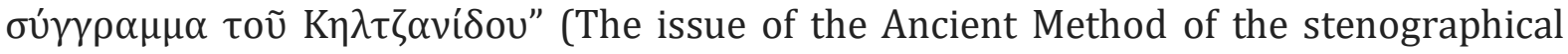
Byzantine Notation and the book of Panagiotes Kiltzanides) Фó $\mu \iota \gamma \xi$ (Formigx). II(a.9) (15.7.1905): 1-2 | II(a.10) (31.7.1905): 3 | II(a.11-12) (15-31.8.1905): 3 | II(a.13-14) (1530.9.1905): 5 | II(a.16) (31.10.1905): 3-4 | II(a.17-18) (15-30.11.1905): 1 \& 5-6.

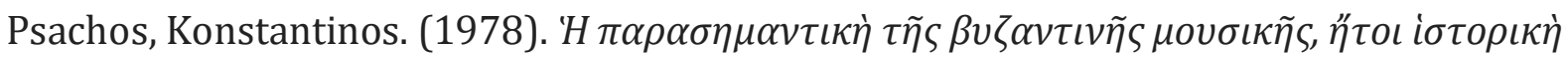

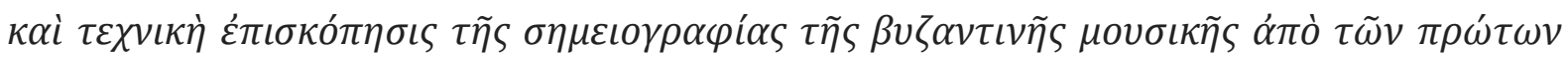

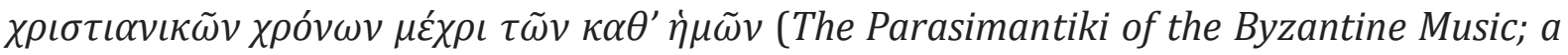
Historical and Technical Review of the Notation of the Byzantine Music from the first Christianity years until nowadays). (2 ${ }^{\text {nd }}$ edition). Athens: Dionysos Publishing Co.

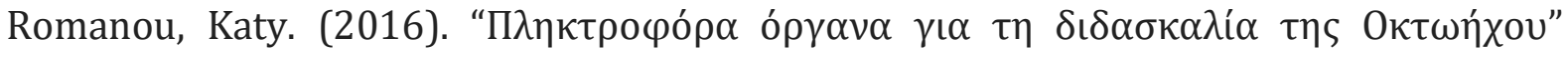
(Keyboard instruments for the teaching of Octoechos). [Video file]. Retrieved from the following site: https://www.pemptousia.gr/video/pliktrofora-organa-gia-ti-didaskaliatis-oktoichou/ [accessed 31 July 2021].

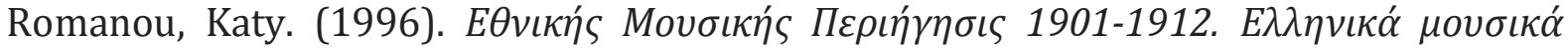

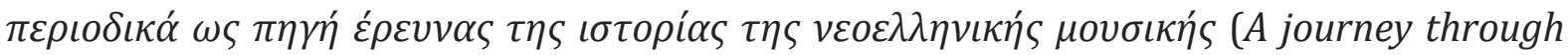
National Music 1901-1912: Greek Music Journals as a source of research on Modern Greek Music). (1 ${ }^{\text {st }}$ part). Athens: Koultoura Editions.

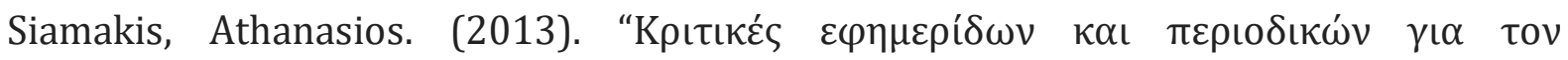

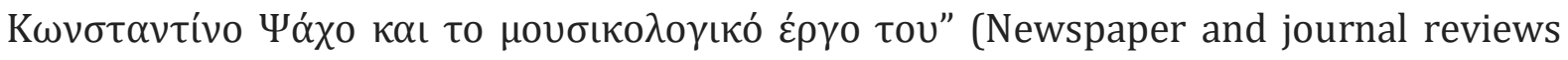

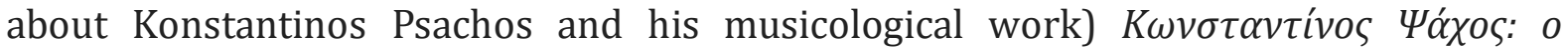




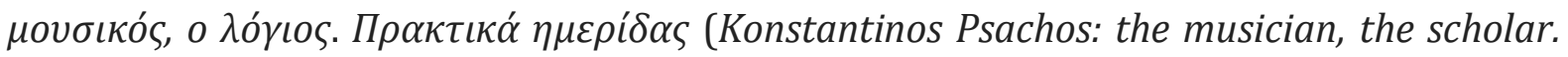
Conference Proceedings), (pp. 135-161). Athens: Publications of the Academy of Athens.

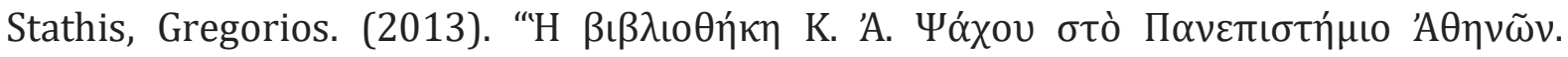

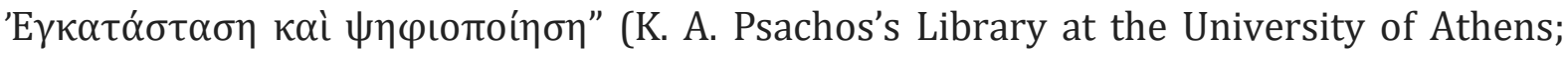

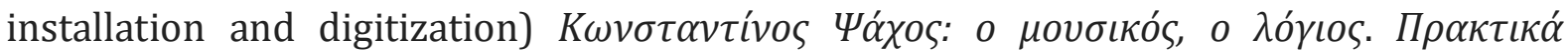
$\eta \mu \varepsilon \rho i \delta \alpha \varsigma$ (Konstantinos Psachos: the musician, the scholar. Conference Proceedings), (pp. 163-175). Athens: Publications of the Academy of Athens.

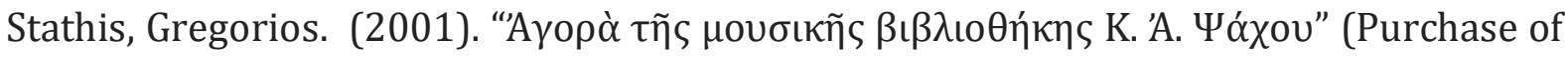

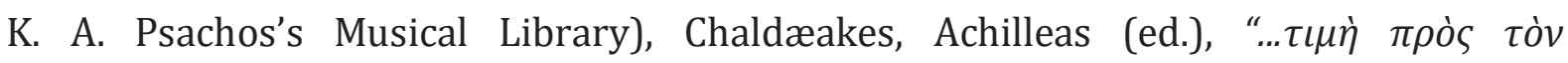

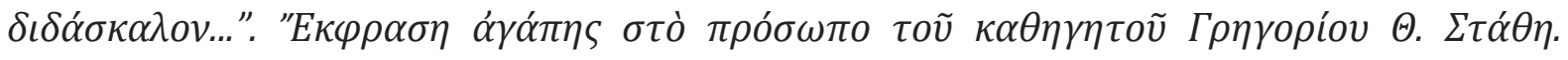
A

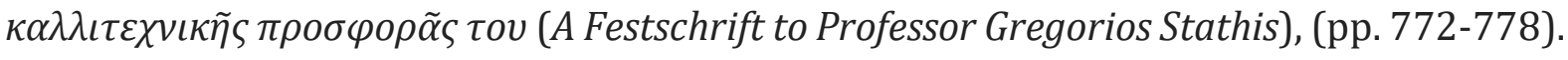

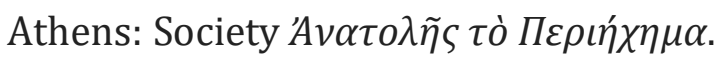

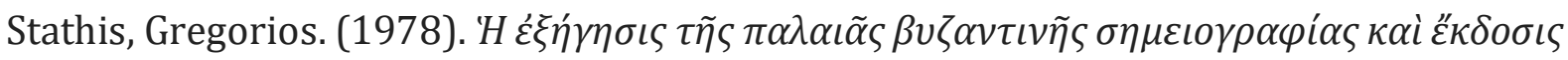

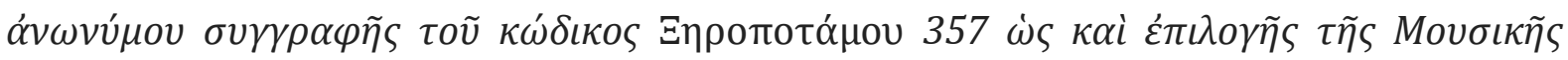

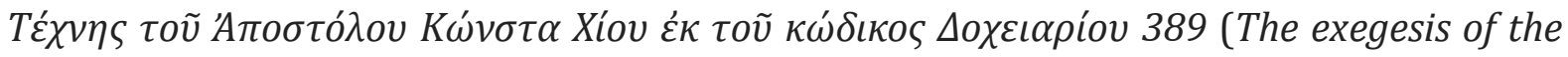
Ancient Byzantine Notation). Athens: Institute of Byzantine Musicology.

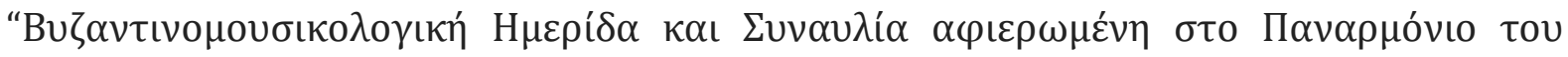

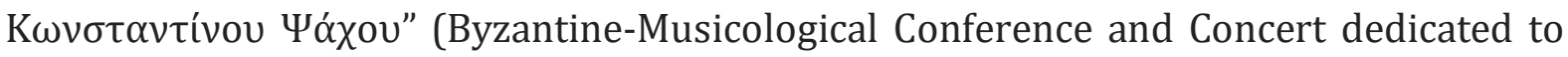
Konstantinos Psachos's Panharmonium). (2016, October 6). Retrieved from https://www.pemptousia.gr/2016/10/vizantinomousikologiki-imerida-ke-sinavliaafieromeni-sto-panarmonio-tou-konnou-psachou/ [accessed 31 July 2021].

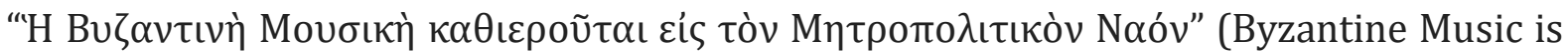

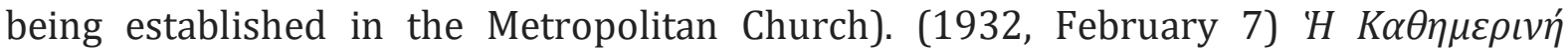
(Kathimerini), p. 4.

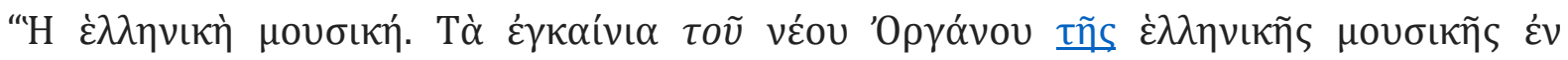

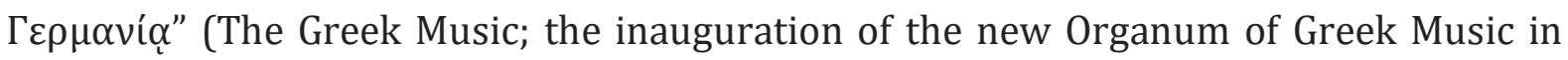

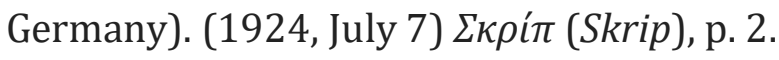




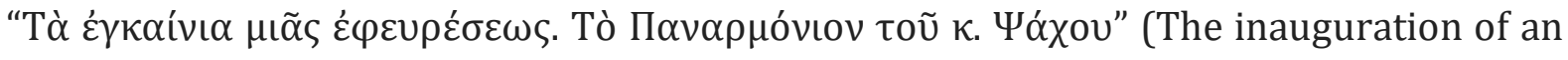

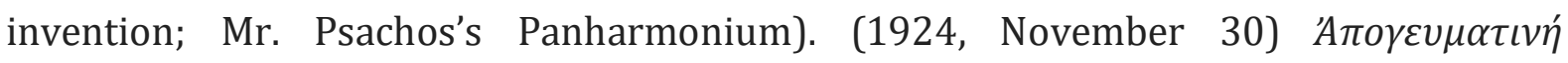
(Apogevmatini), p. 3. 


\section{Facsimiles [facs.]}

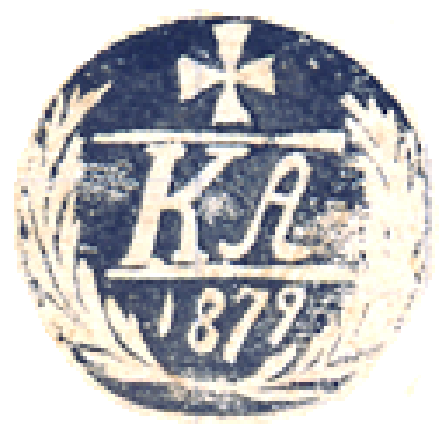

Facs. 1 K. A. Psachos’s characteristic special oval seal. (ㄷ K. A. Psachos Archive)

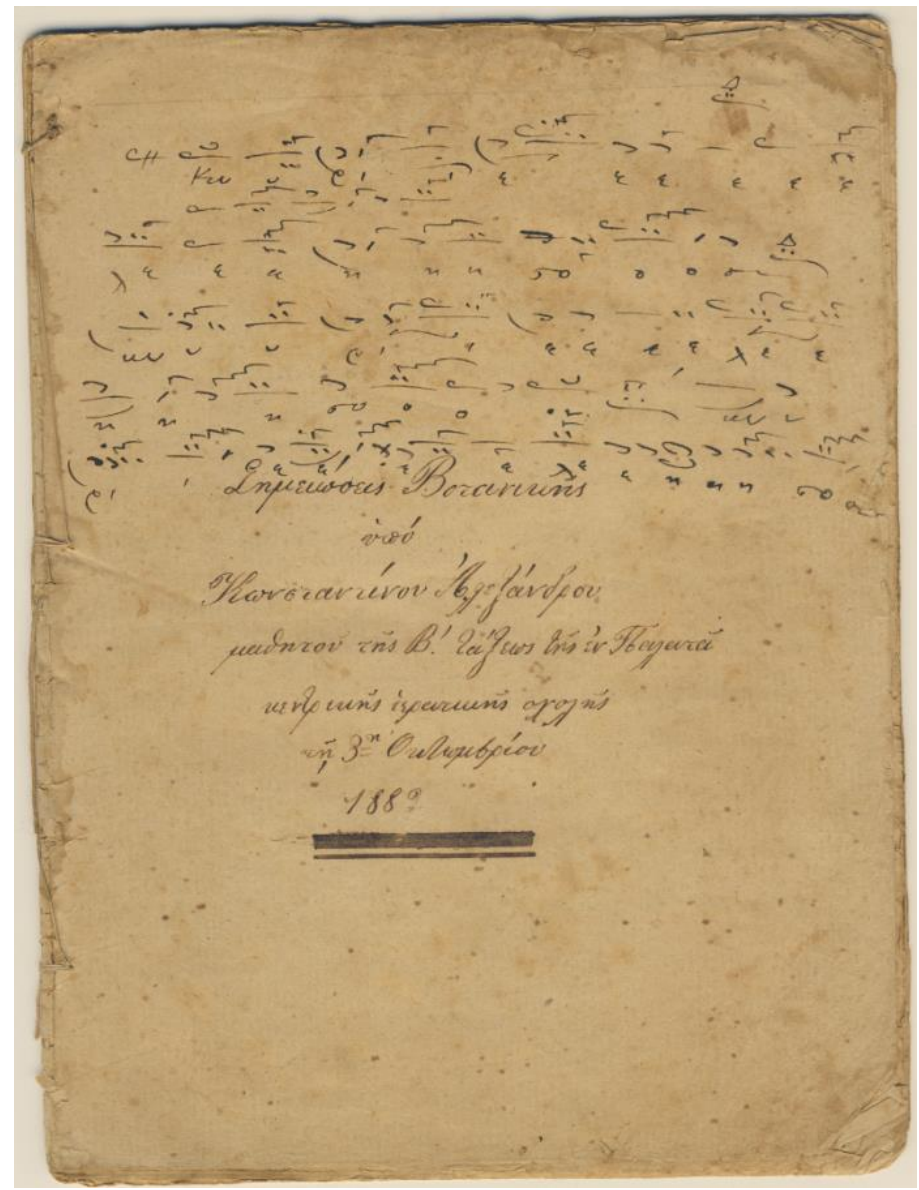

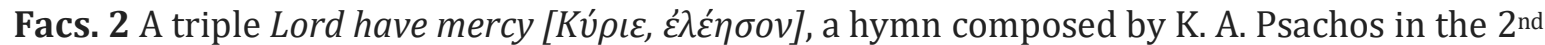
Mode of Byzantine Music, written on the cover page of one of his student notebooks. (C) K. A. Psachos Archive) 


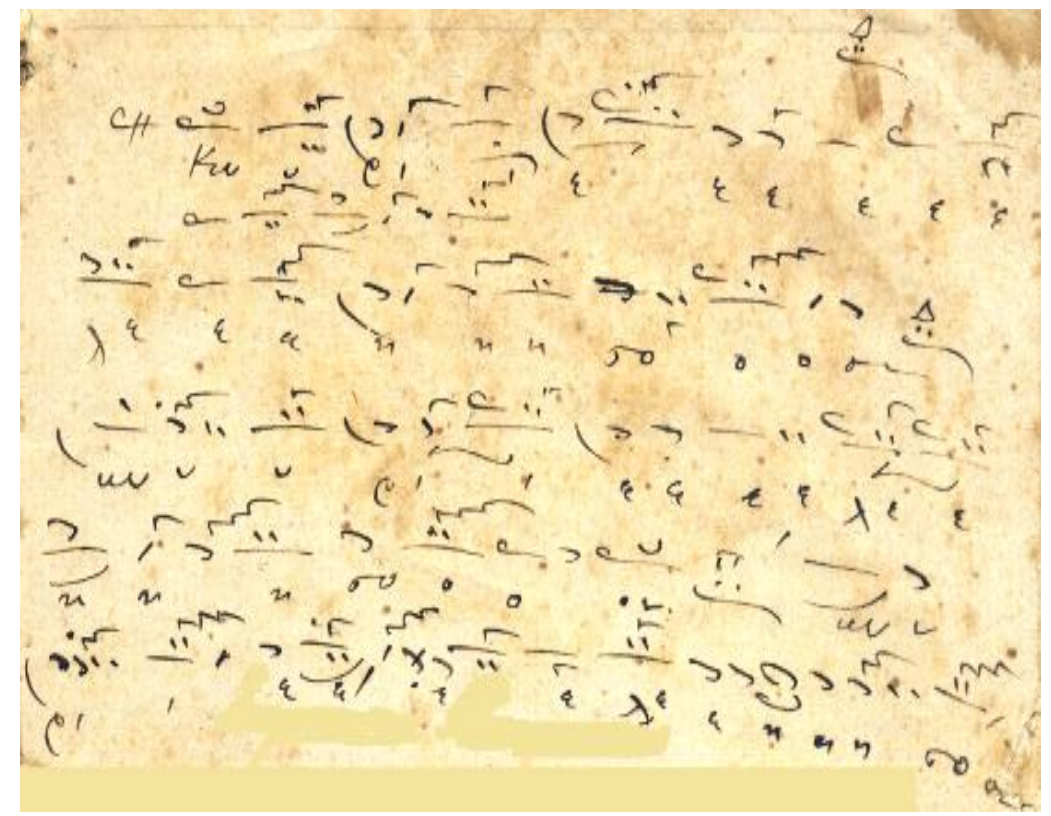

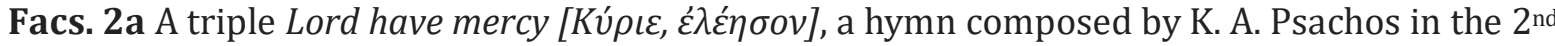
Mode of Byzantine Music, written on the cover page of one of his student notebooks (detail). (C) K. A. Psachos Archive)

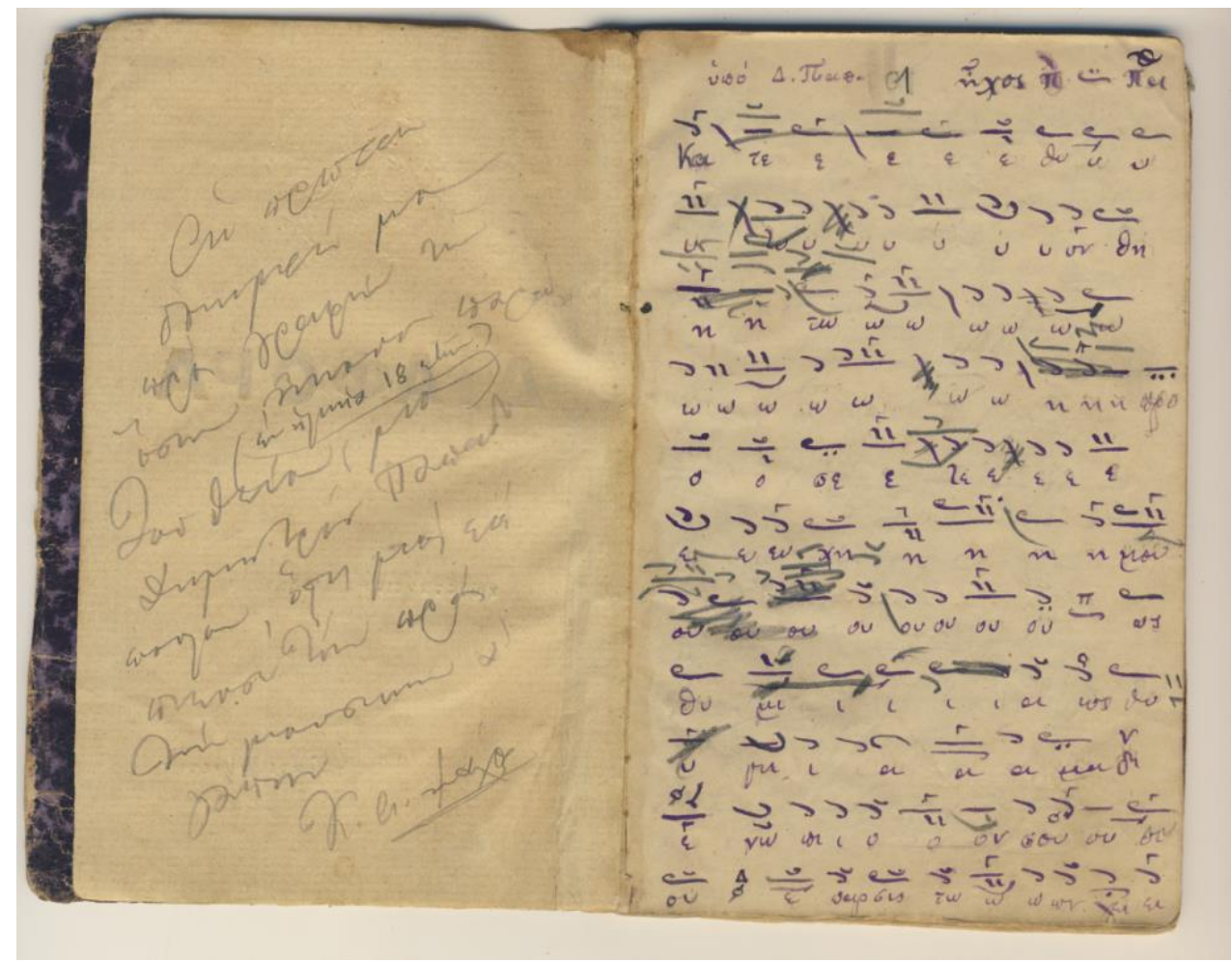

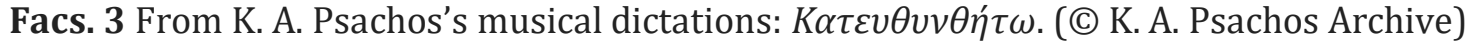




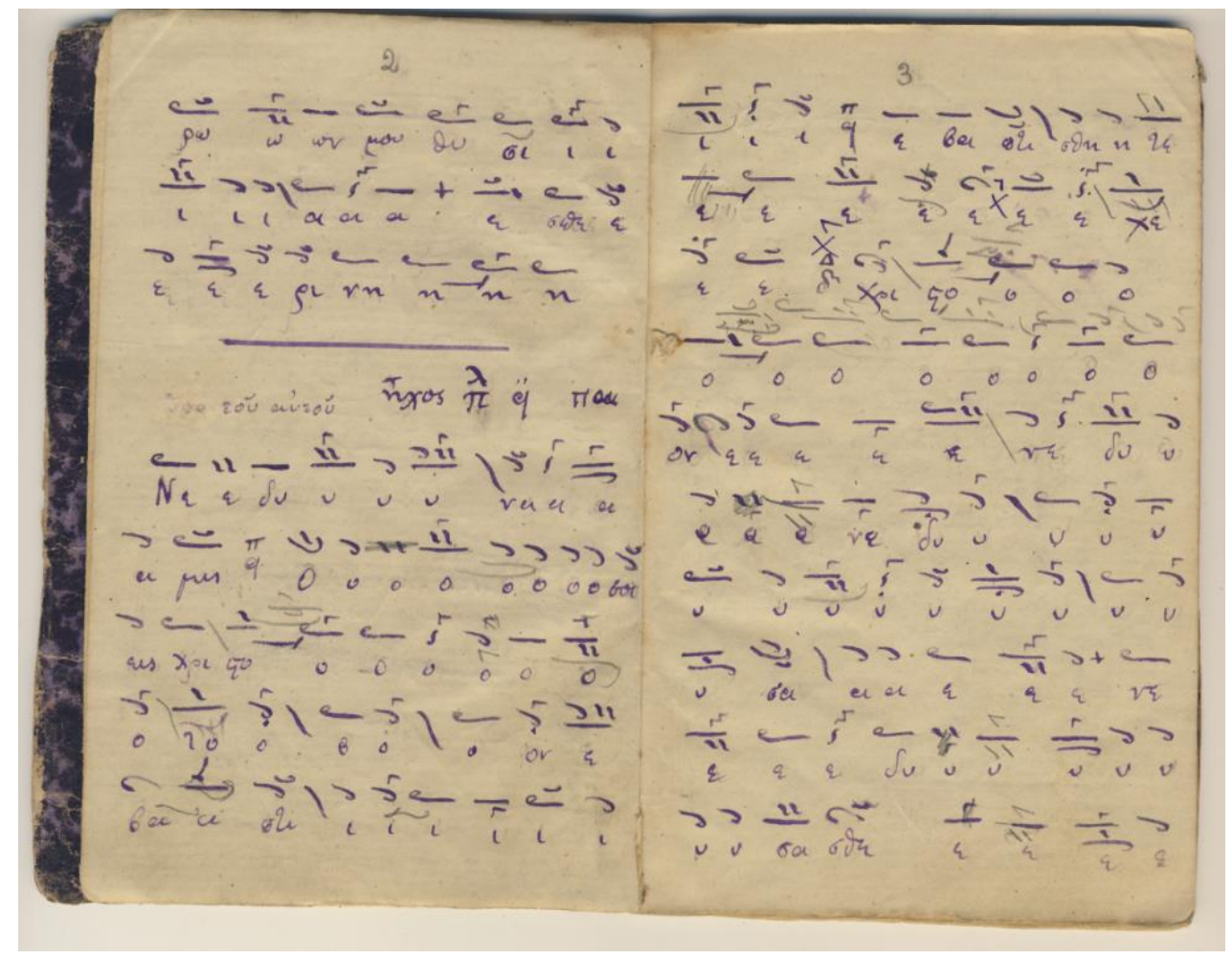

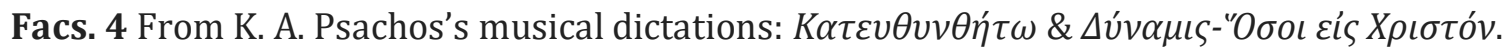
(C) K. A. Psachos Archive)

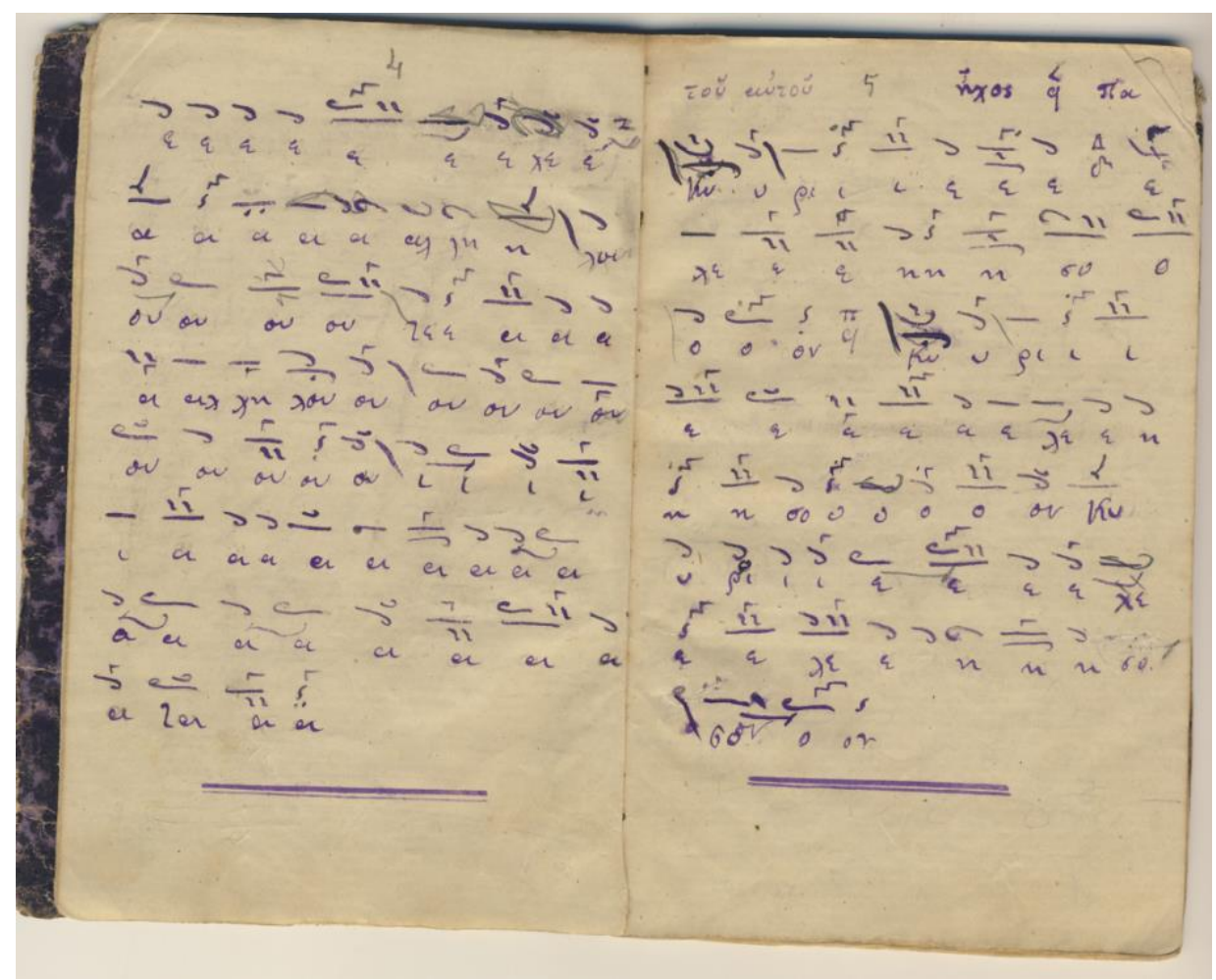

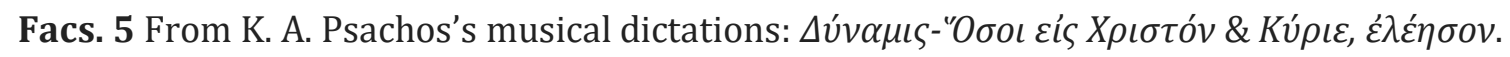
(C) K. A. Psachos Archive) 


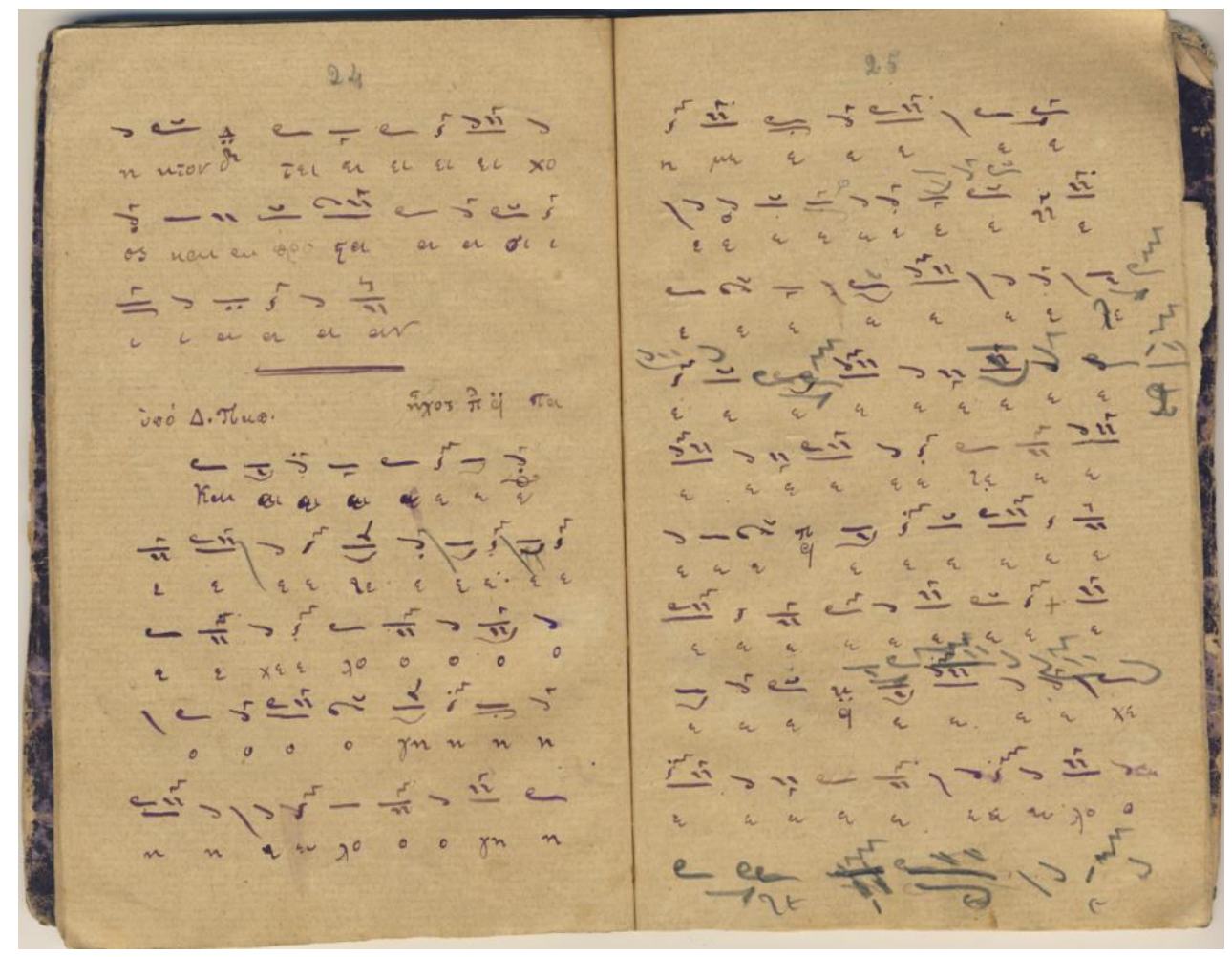

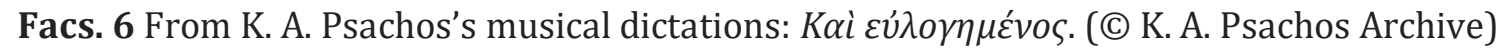

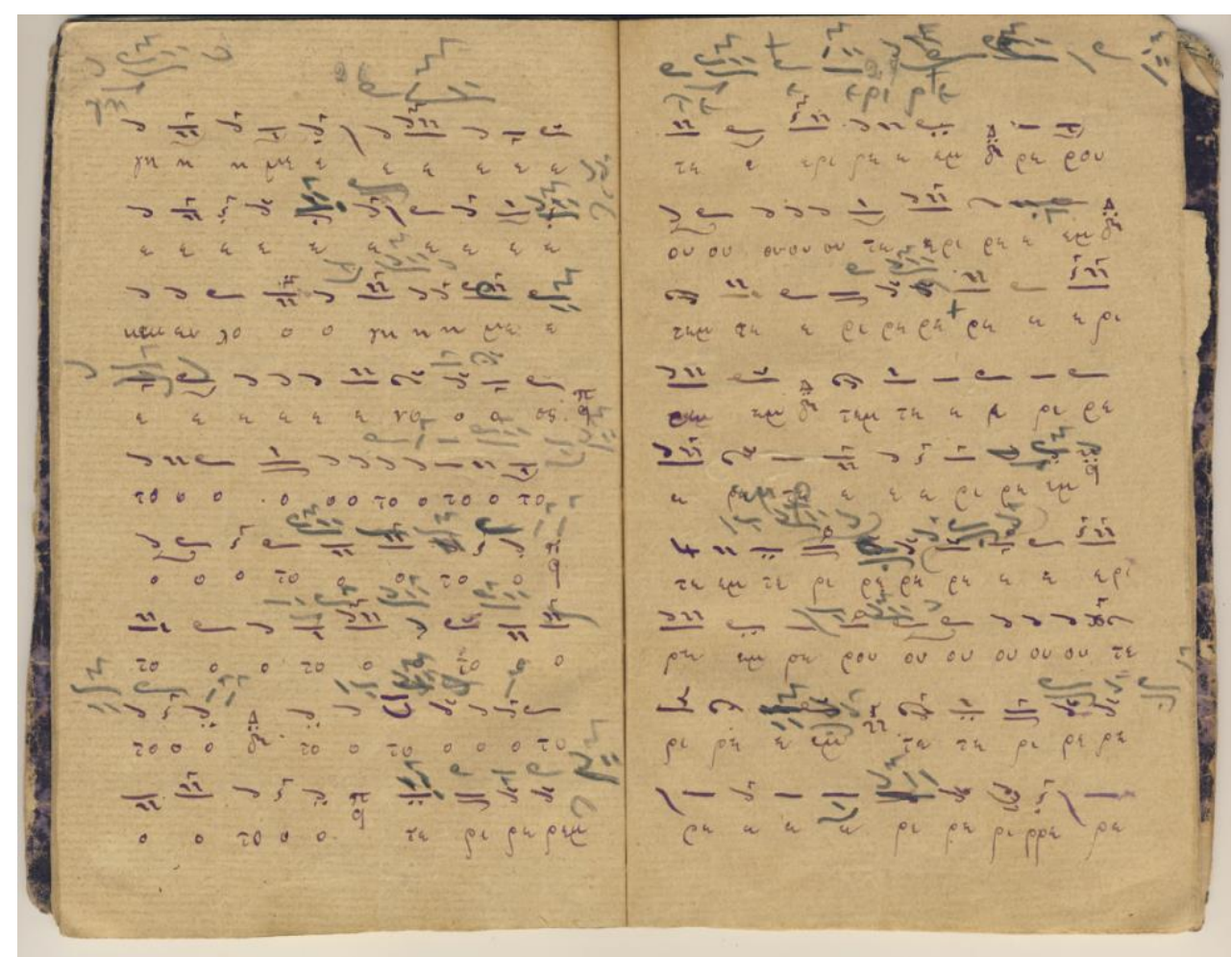

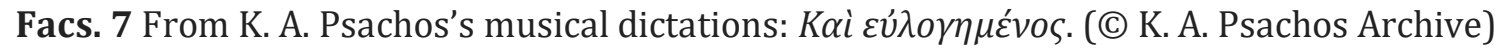




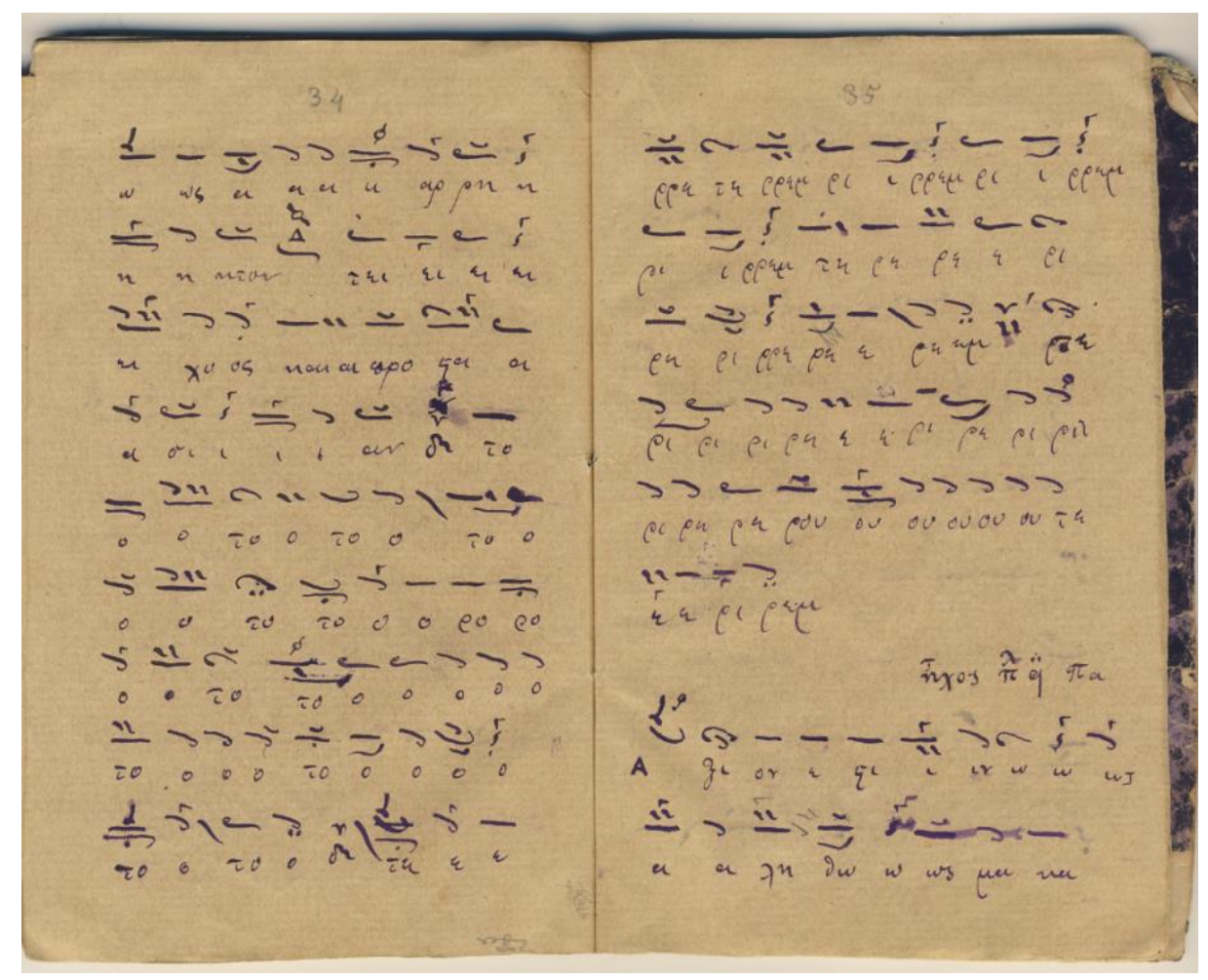

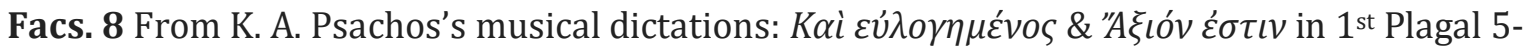
phonos Mode. (C) K. A. Psachos Archive)

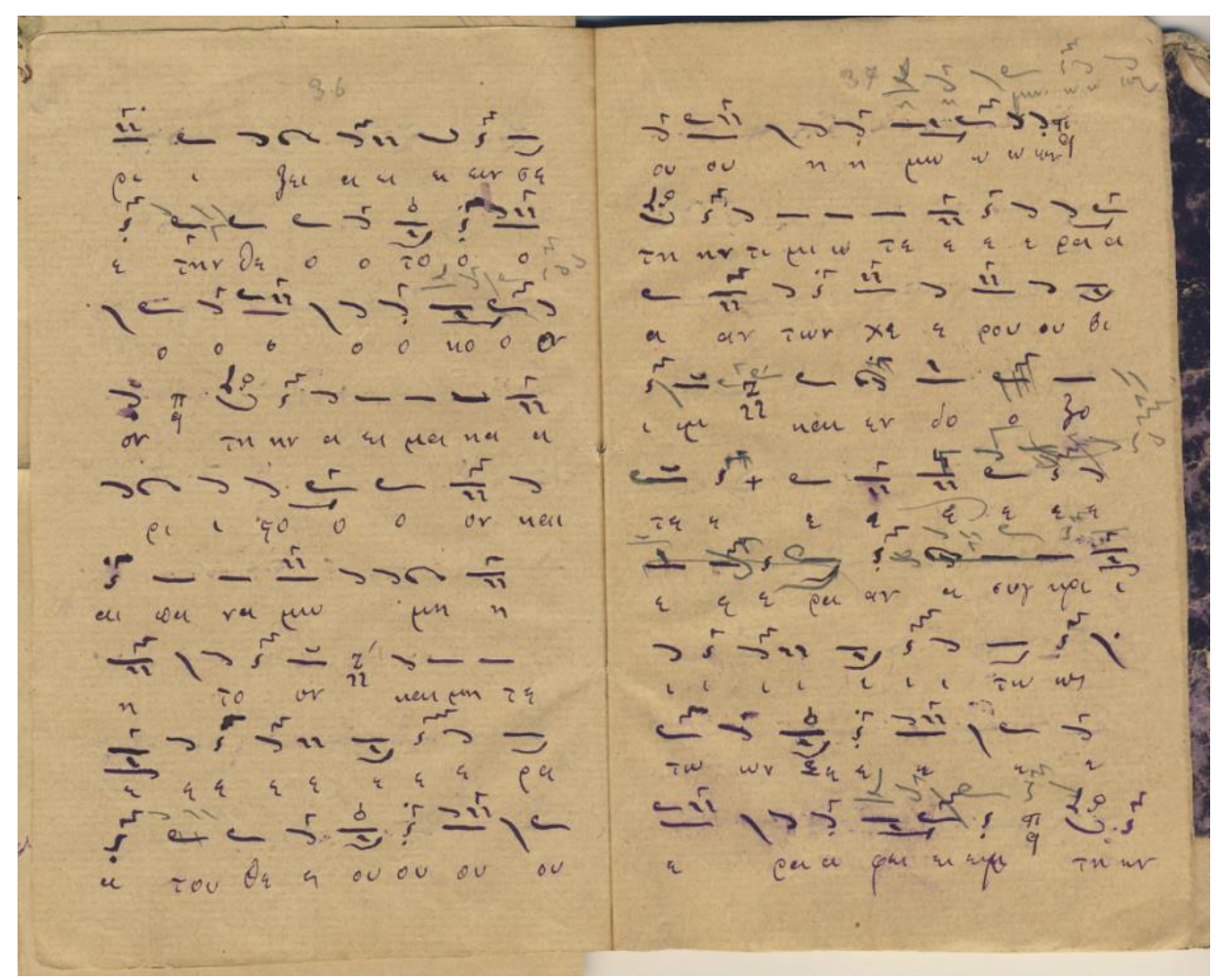

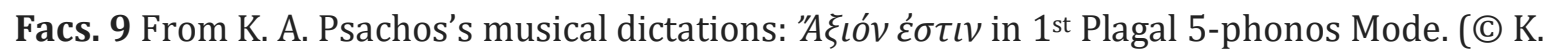
A. Psachos Archive) 


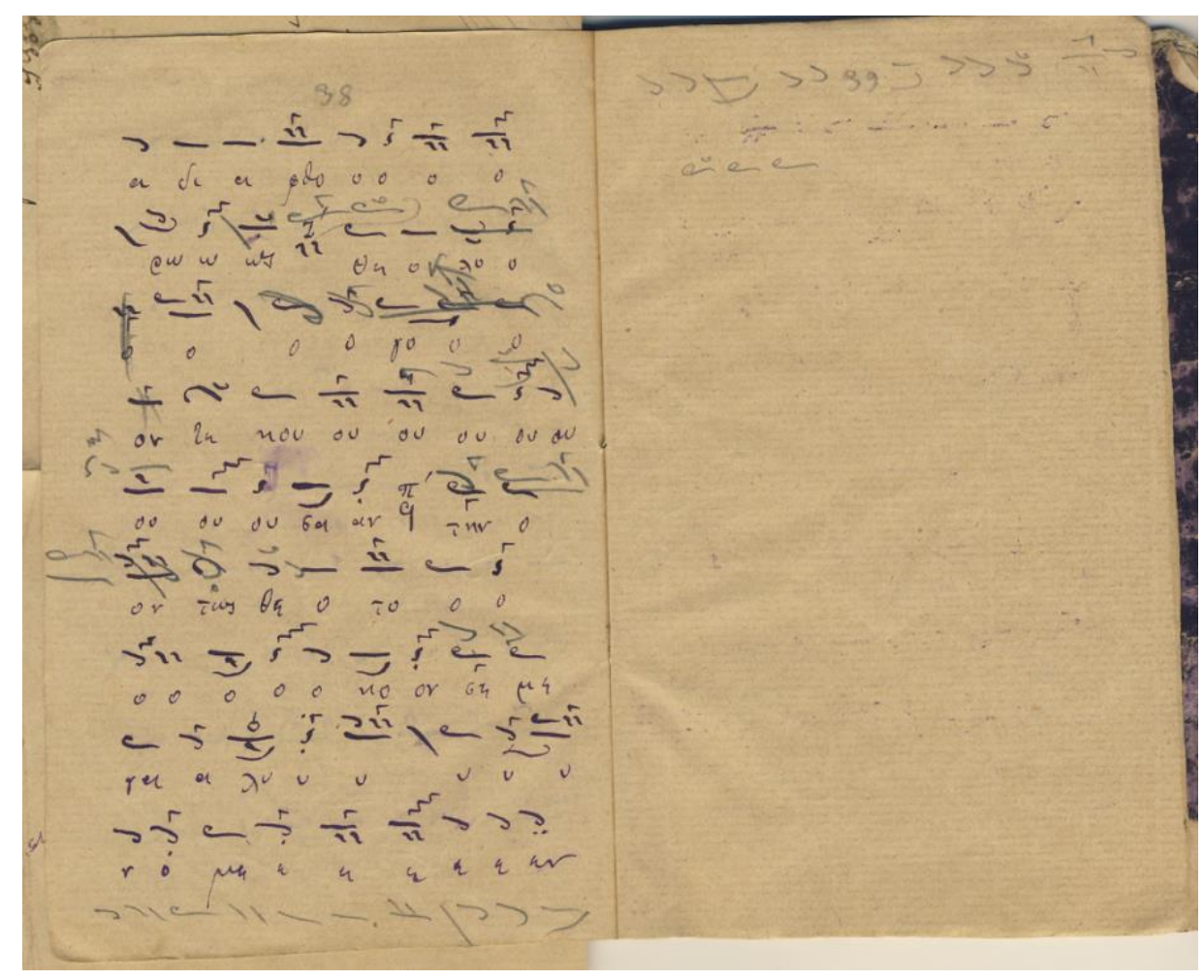

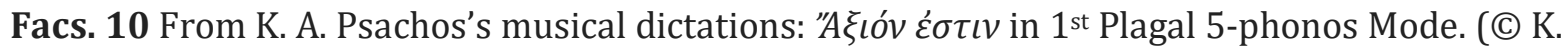
A. Psachos Archive)

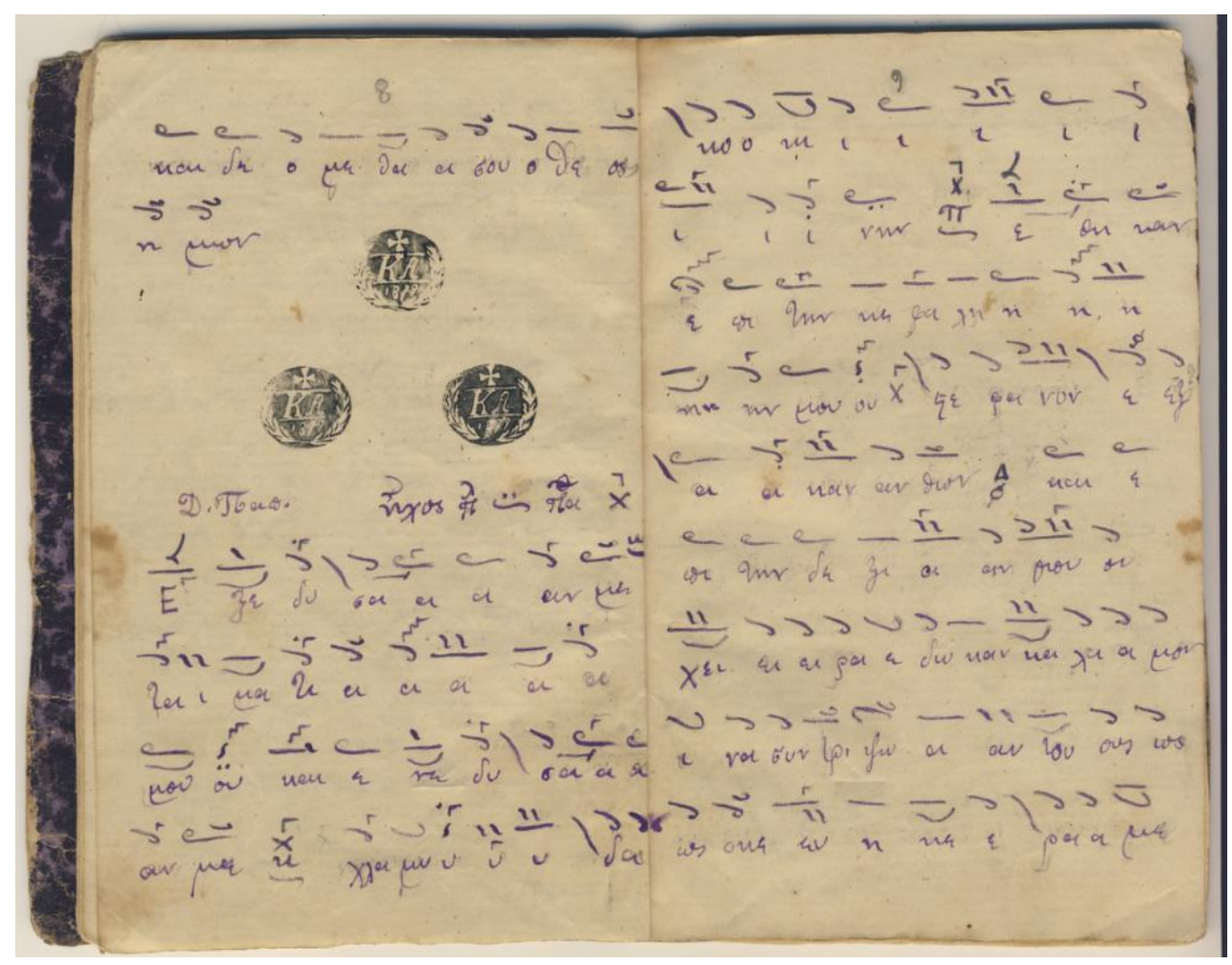

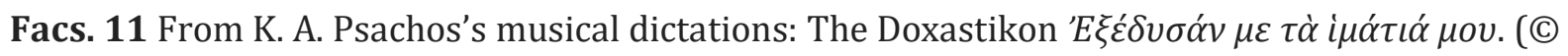
K. A. Psachos Archive) 


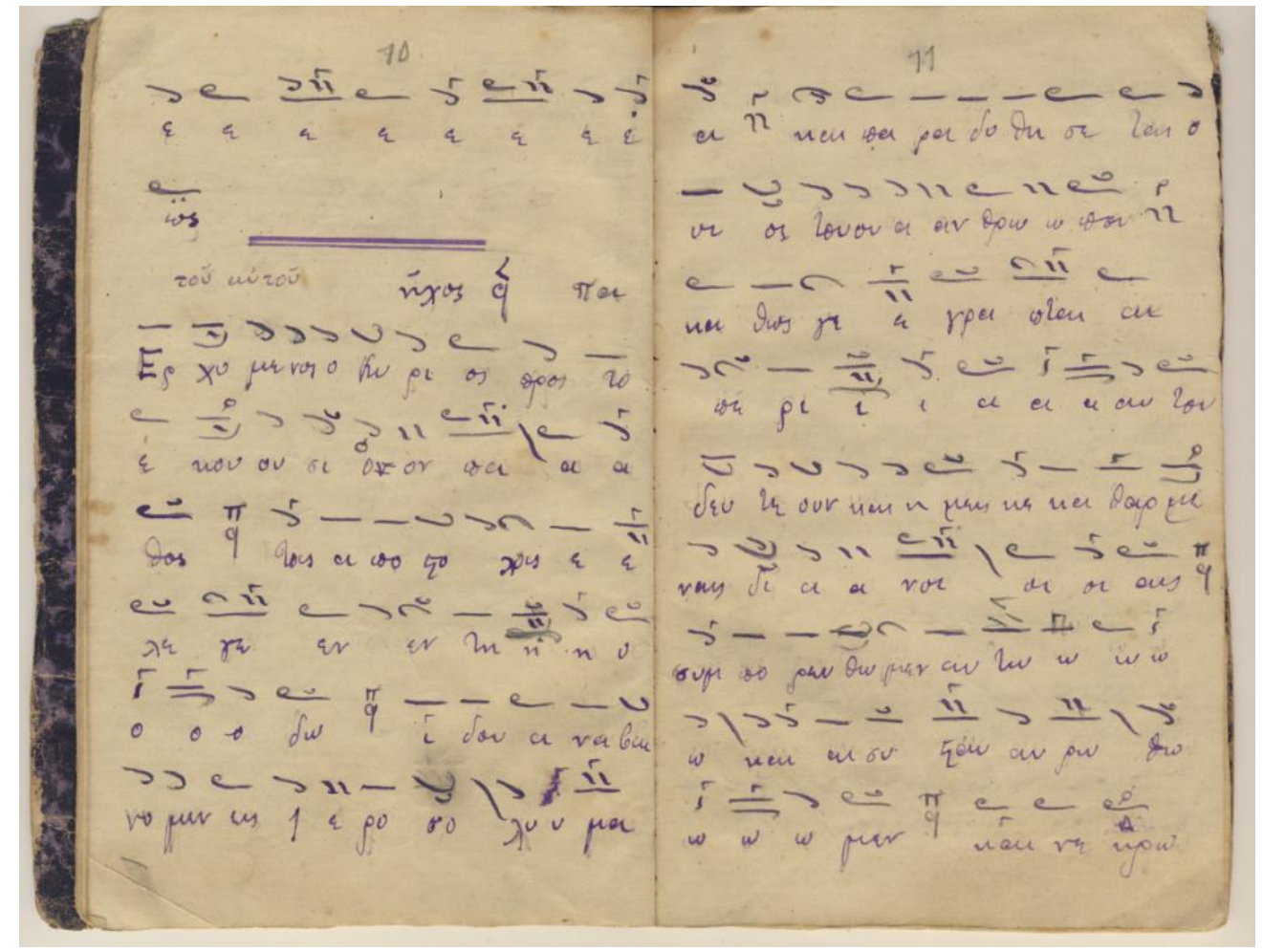

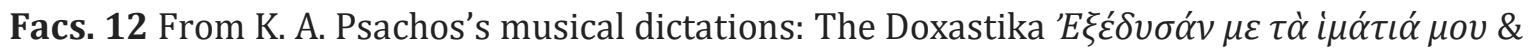

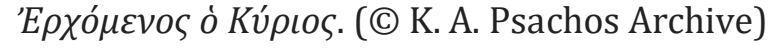

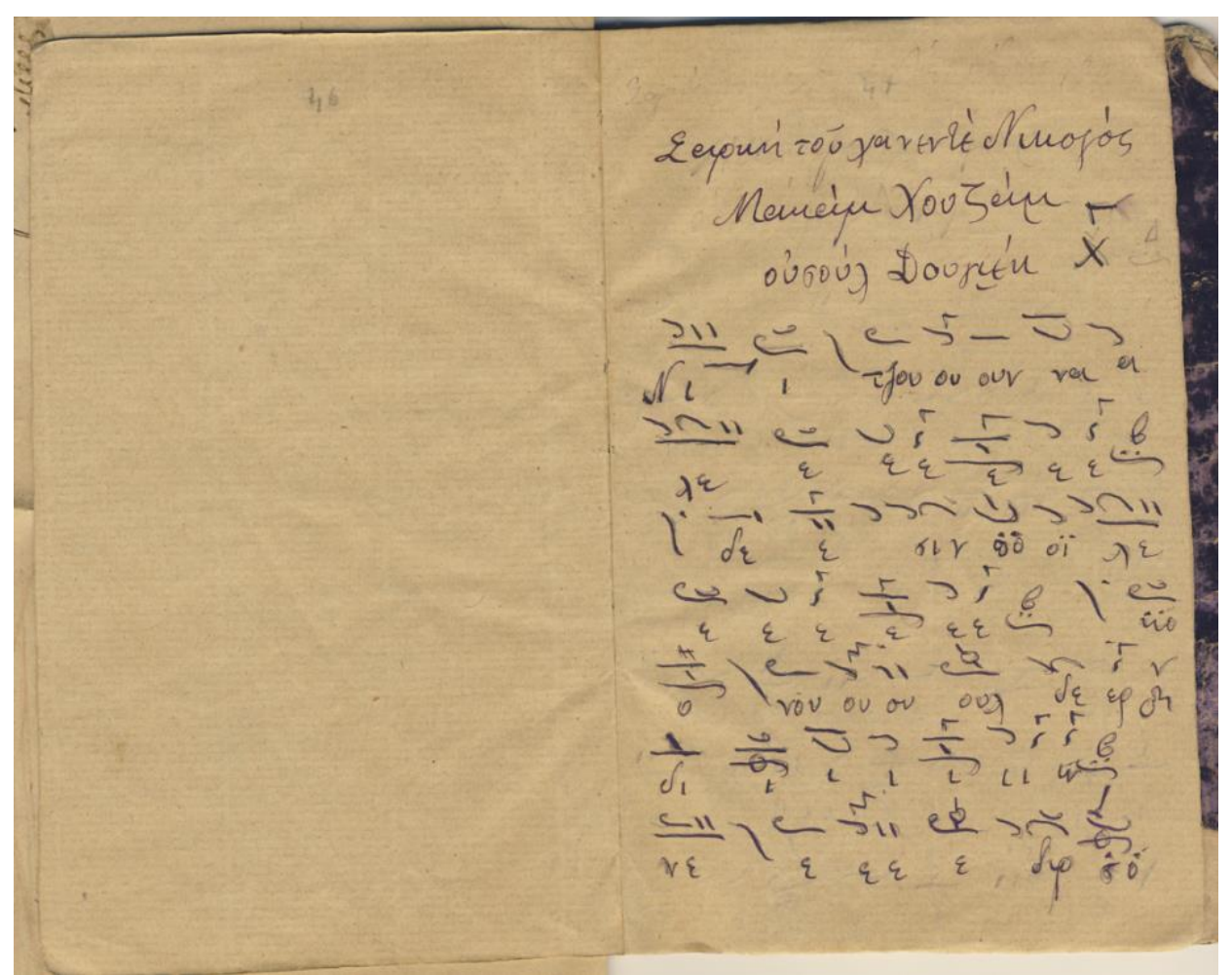

Facs. 13 From K. A. Psachos's musical dictations; a musical score of a Sarkı composed by the

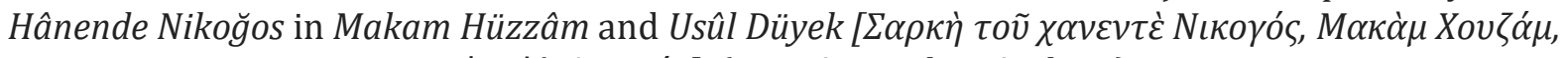

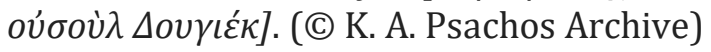




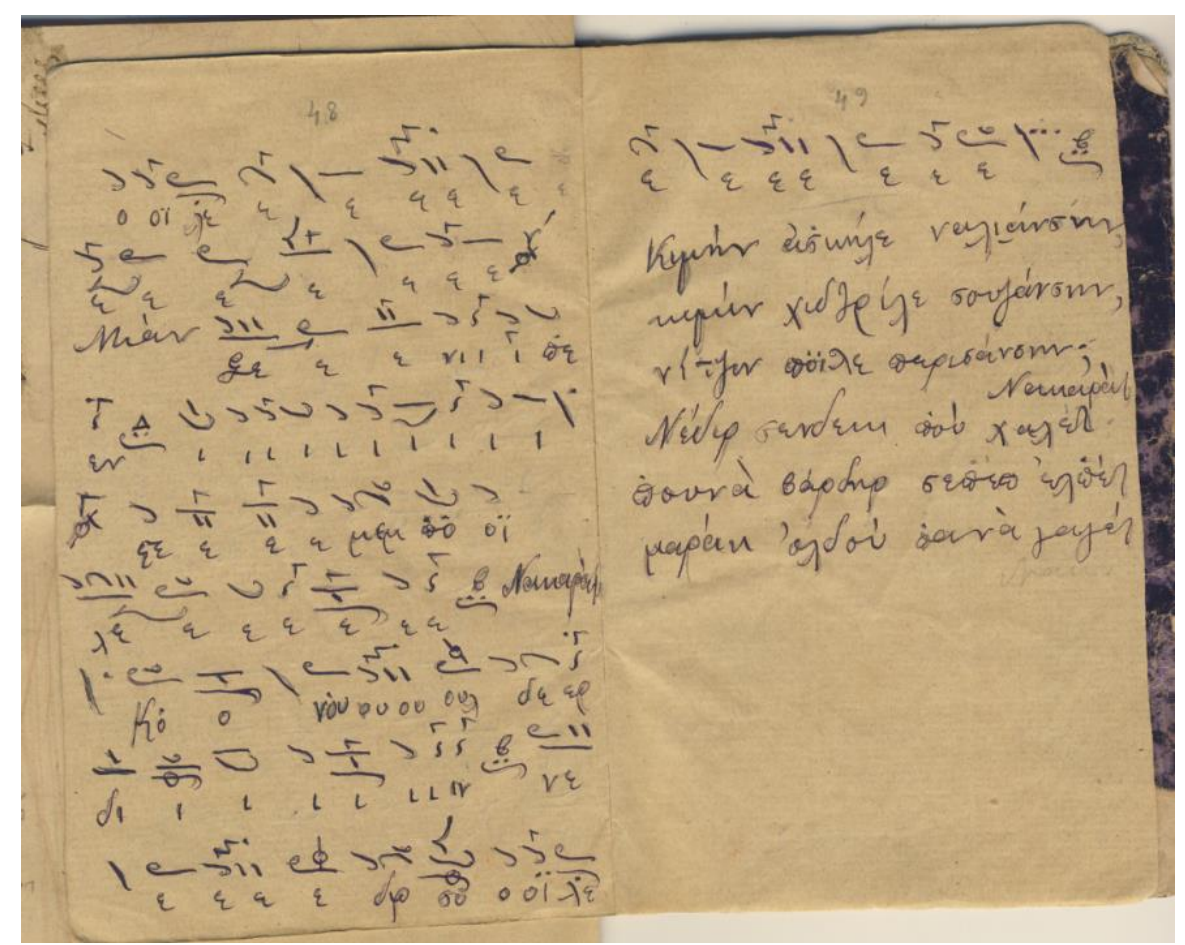

Facs. 14 From K. A. Psachos's musical dictations; a musical score of a Şarkı composed by the

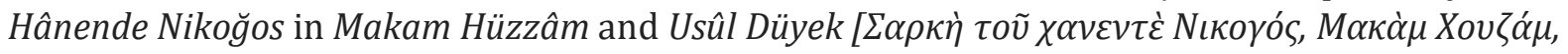

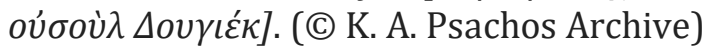

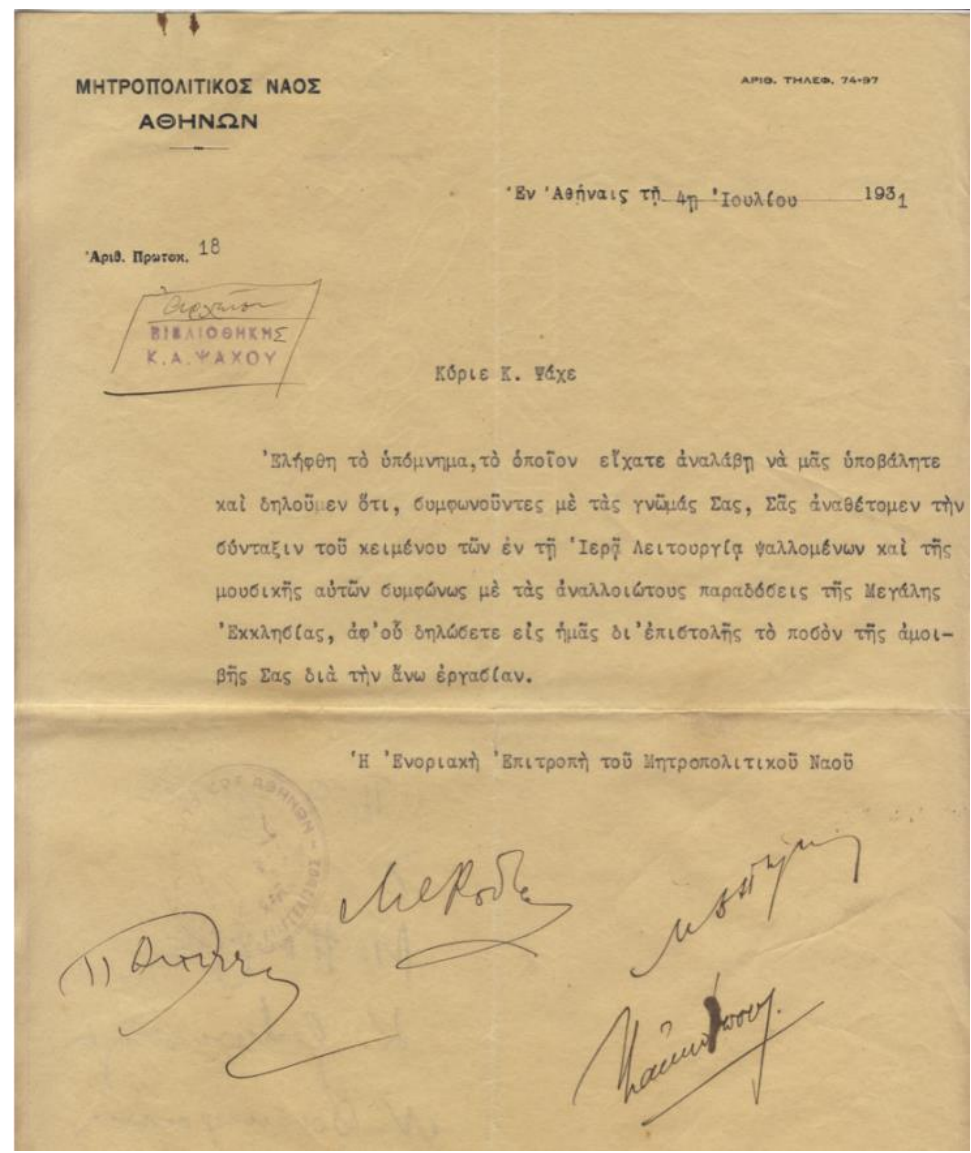

Facs. 15 An epistle to K. A. Psachos from the Council of the Metropolitan Church of Athens. (C) K. A. Psachos Archive) 


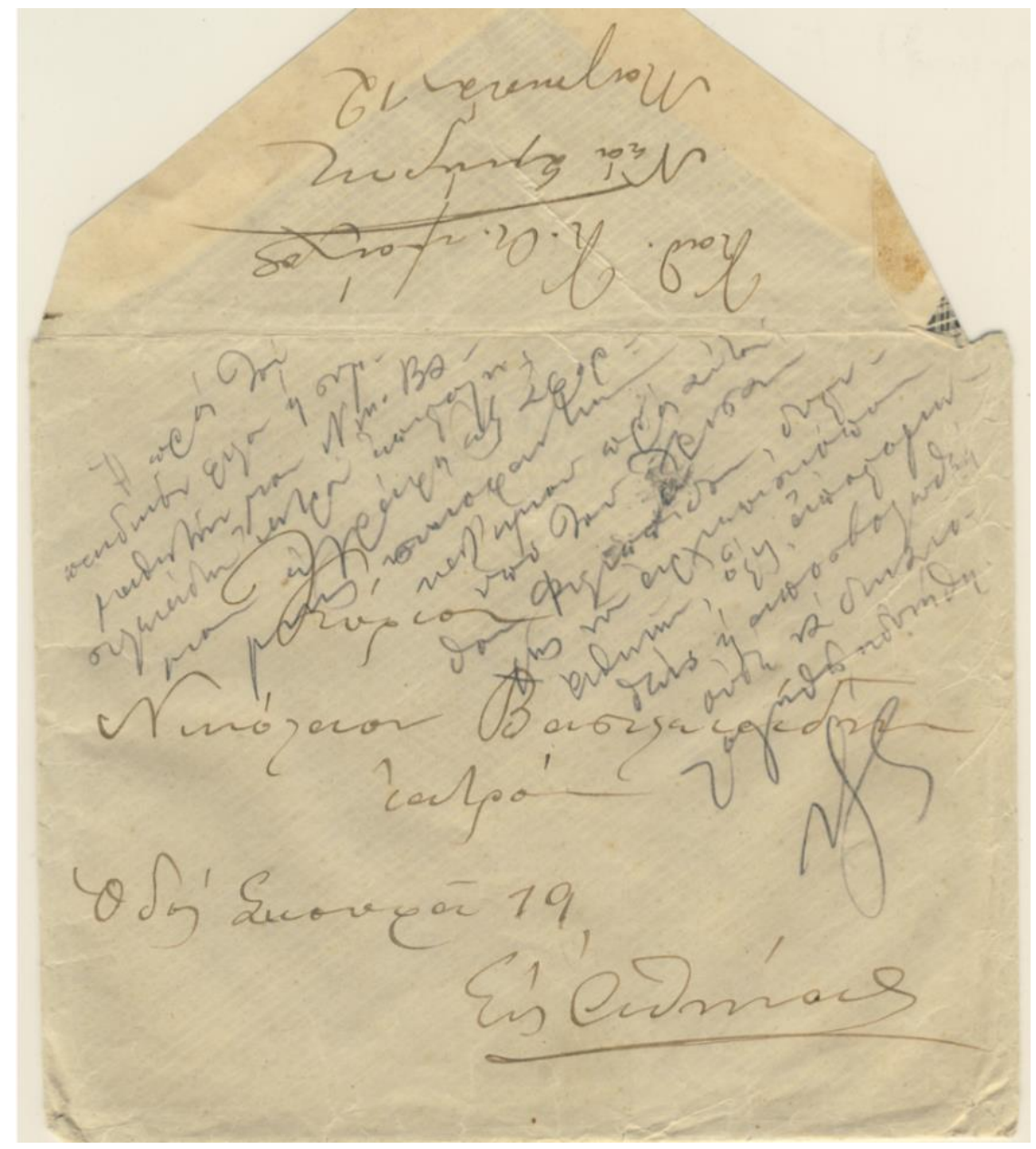

Facs. 16 A memo of K. A. Psachos, written on an envelope. (ㄷ K. A. Psachos Archive) 


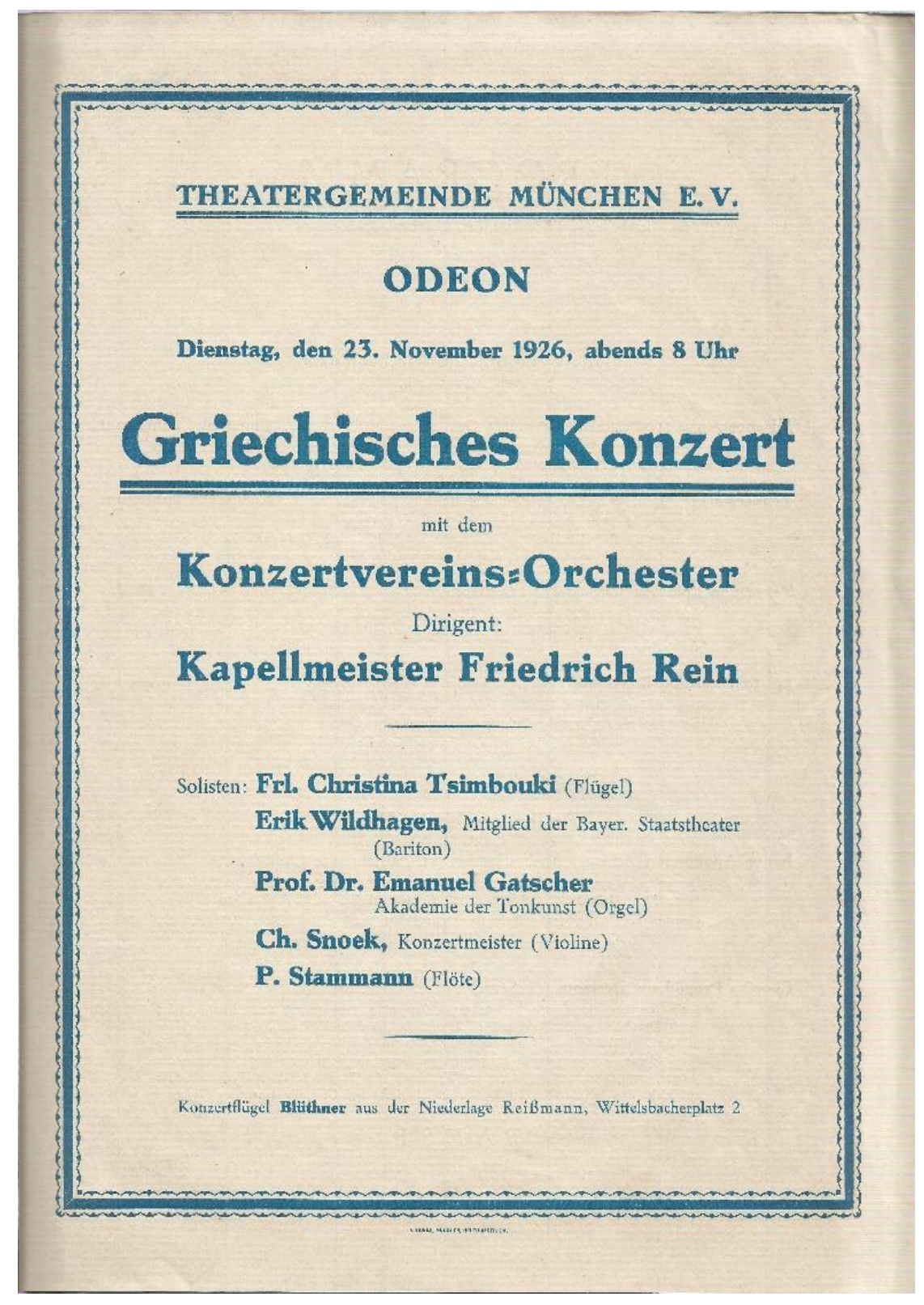

Facs. 17 The Program of a concert given by K. A. Psachos in Munich in 1926. (C) K. A. Psachos Archive) 


\section{PROGRAMM}

zusammengestellt und bearbeitet von Konstantin A. Psachos, Professor der griechischen Musik, Athen

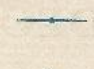

I.

Alte byzantinische Kirchenmusik

( $800-1800$ n. Chr.)

1. Mi apostrepsis (Orchester) "Und verbirg Dein Angesicht nicht" . , Komponist unbekannt Vers ans dem 69. Ysalm Davids Alte Mclodie eines urbekannten Komponisten. Lied der grotien Fas

2. Ti lpermacho (Orchestet) „Der großen Kämpferin...". . . . Komponist unbekannt Aus dem Akathistoss:Hymnus, der in der Madonnarkirche in Vlacheme bei Konstantinopel gesungen wurde als Dankespäan an die Mutter Gottes, dnrch deren Gnade unter der Regierung
des Kaisers Meraklius ( $(226 n$, (Chr), dic Byzantiner yor dem Ansturn der Avaren gerertitet wurden

3. Trisságion Epitafiou (Orchester) Karfreitags:Gesang.

Die Melodie ist ein Meisterwerk des 15. Jahrhunderts. Der Komponist ist Johann Kladas, Chorsänger in der Aja Sofia. Das Lied wird gesungen beim Umhertragen des Gekreuzigten am Karfeitag.

4. Epi ton potarán Babylonos (Orgel) „An den Wassern Babylons ..." . . . Churmusios Der 136. Psalm Davids. Die Wehklage der Juden aut den Flasse Ruplrat. Kumpuniert von
Charemuslog, Archivar der (Orthodoxen Kirche (1500 n. Chr.).

Solist: Prof, Dr. Emanuel Gatscher

II.

Antike griechische Musik

5. Imnos Apollonos (Orchester) $\Lambda$ pollo:Hymnus (ca, 280 Jahre vor Chr.) Der erste Teil der ApolloeHymne „Den im Kitharaspiel ruhmetichen Jingling...., die in Jahre 1894 in Dulphi entdeckt wurde, tur Orchester bearbeitet von K. A. Paschos. Gesang: Erik Wildhagen von der Raycrischen Staatsoper Flöte: Y. Stammann

6. Chorika Promitheos Desmotu (Orchester)

Sechs Strophen der Chorlieder aus dem "Gefesselten Prometheus" des Aschylos. Von im Anriken Theartor

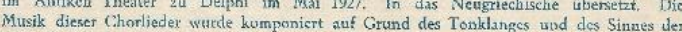
Wörter, zum Zweck der vollkommenen Wiedergahe des Textes. Jedem musikalischen Satz entspricht eine besondere Bewegung der im altgriechischen Gewande taazenden Mädchen.

$$
\text { P A U S E }
$$

Facs. 18 The Program of a concert given by K. A. Psachos in Munich in 1926. (@ K. A. Psachos Archive) 


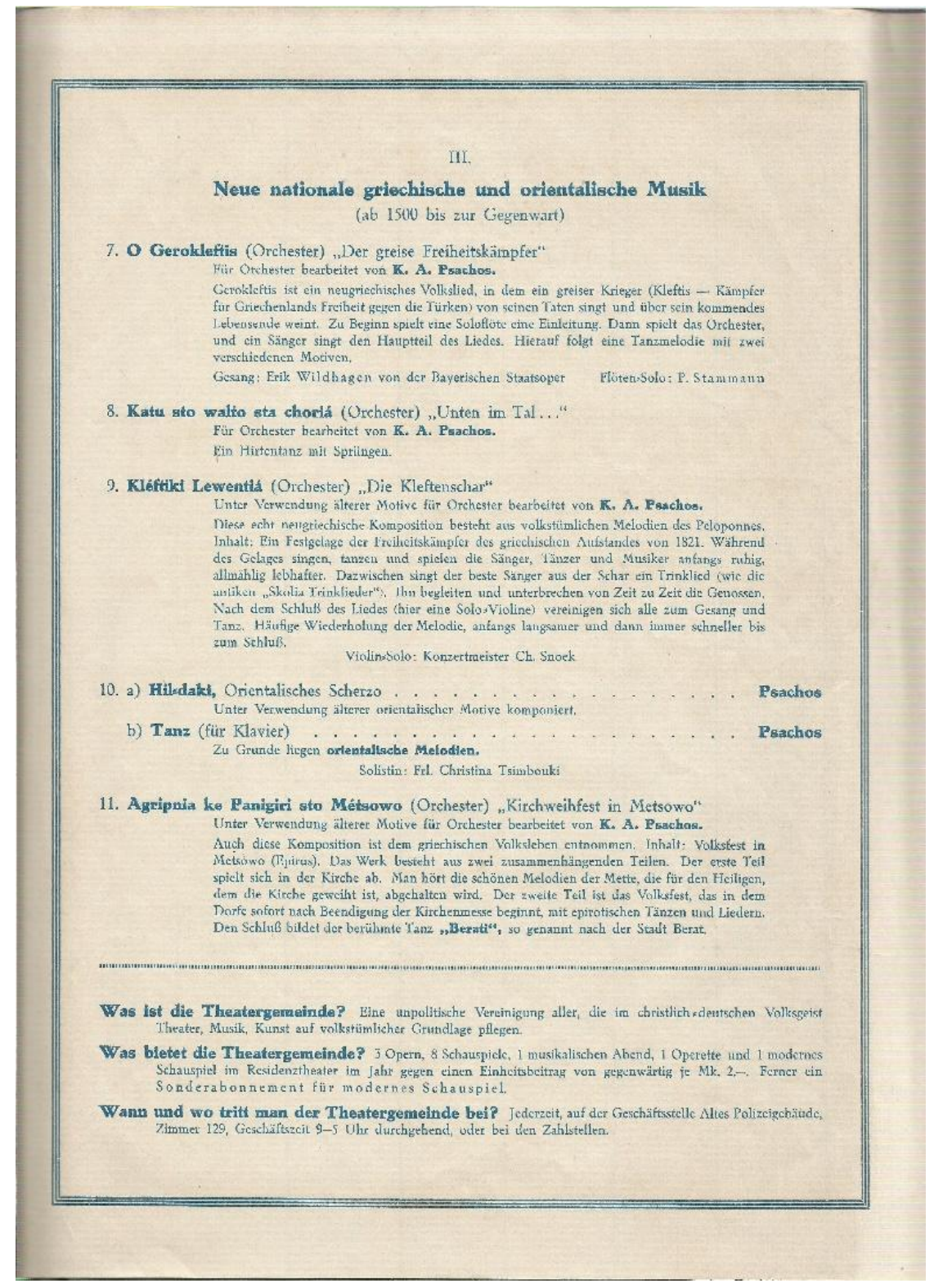

Facs. 19 The Program of a concert given by K. A. Psachos in Munich in 1926. (C) K. A. Psachos Archive) 


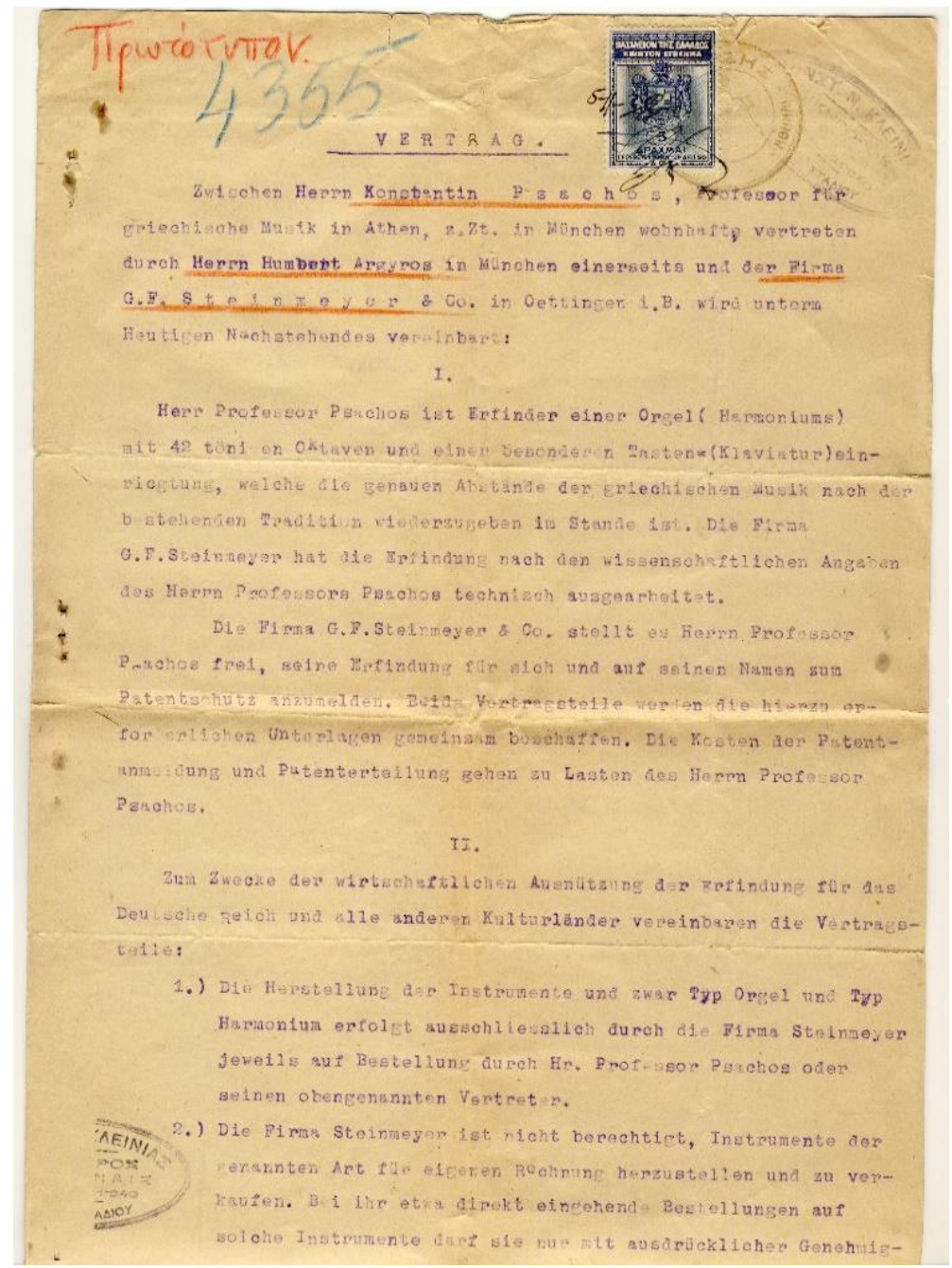

Facs. 20 The contract K. A. Psachos's signed with the Steinmeyer Company in 1938 about the Panharmonium. (C K. A. Psachos Archive) 


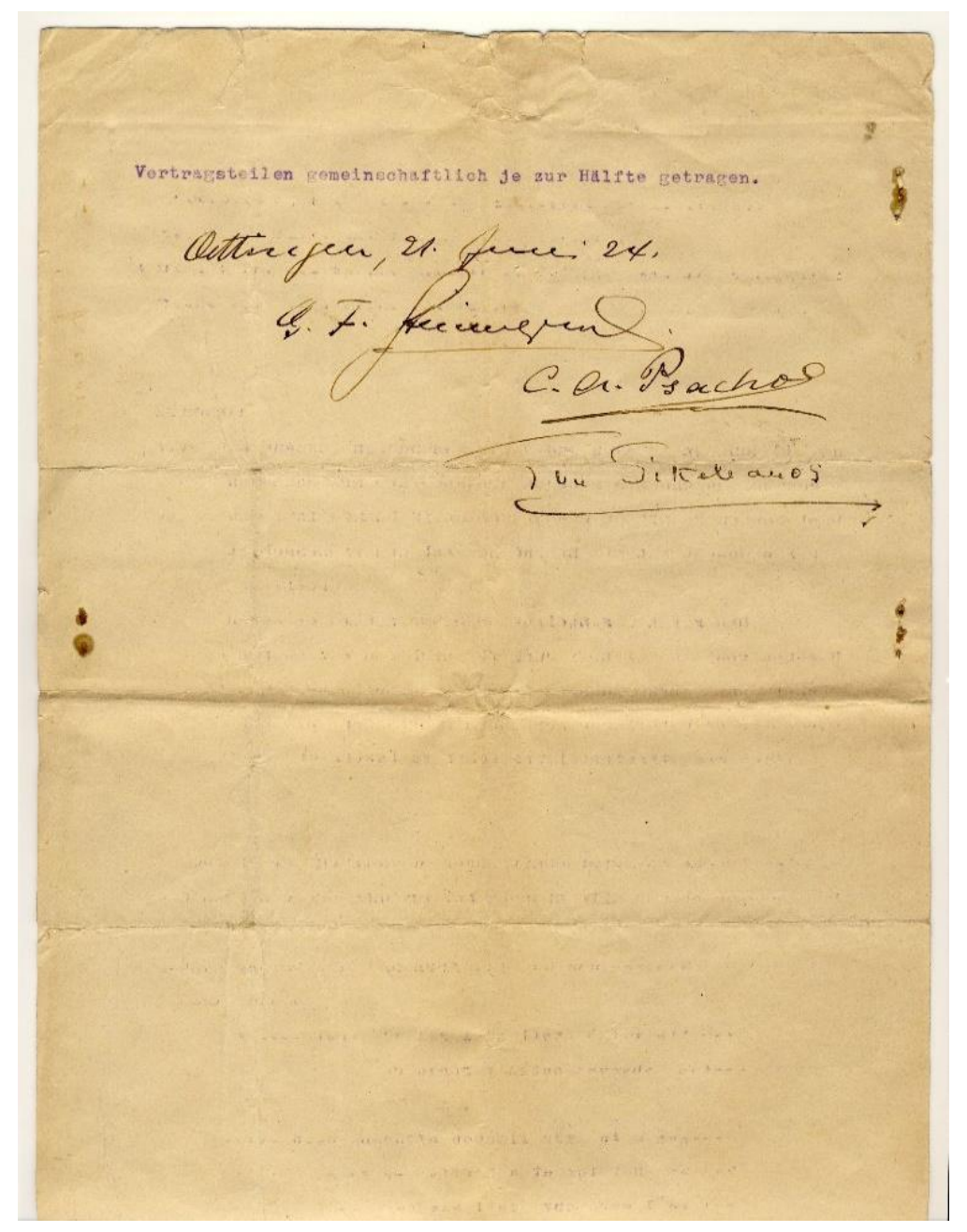

Facs. 21 The contract K. A. Psachos's signed with the Steinmeyer Company in 1938 about the Panharmonium. (C) K. A. Psachos Archive) 


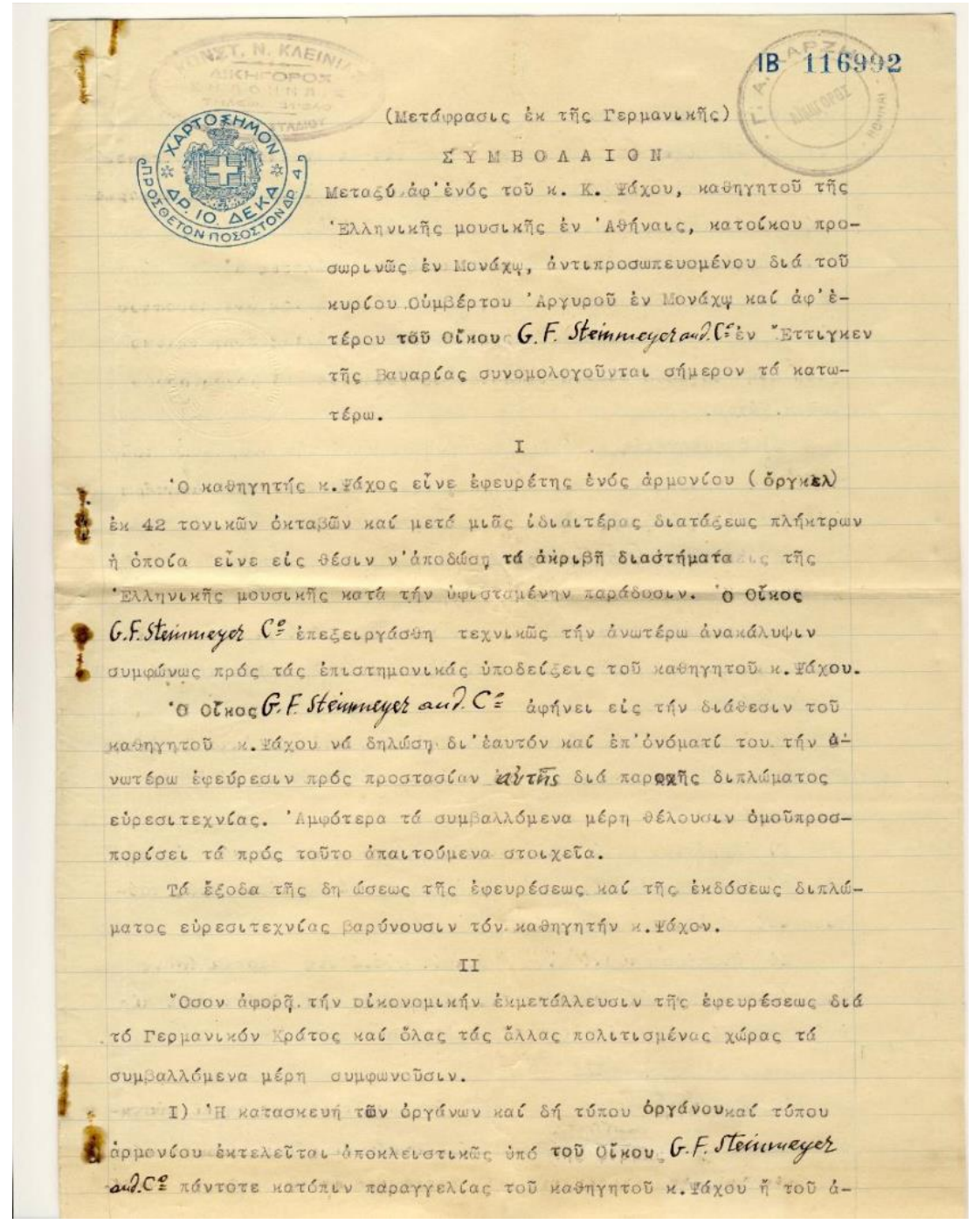

Facs. 22 The Greek translation of the contract K. A. Psachos's signed with the Steinmeyer Company in 1938 about the Panharmonium. (ㄷ K. A. Psachos Archive) 
Figures [figs.]

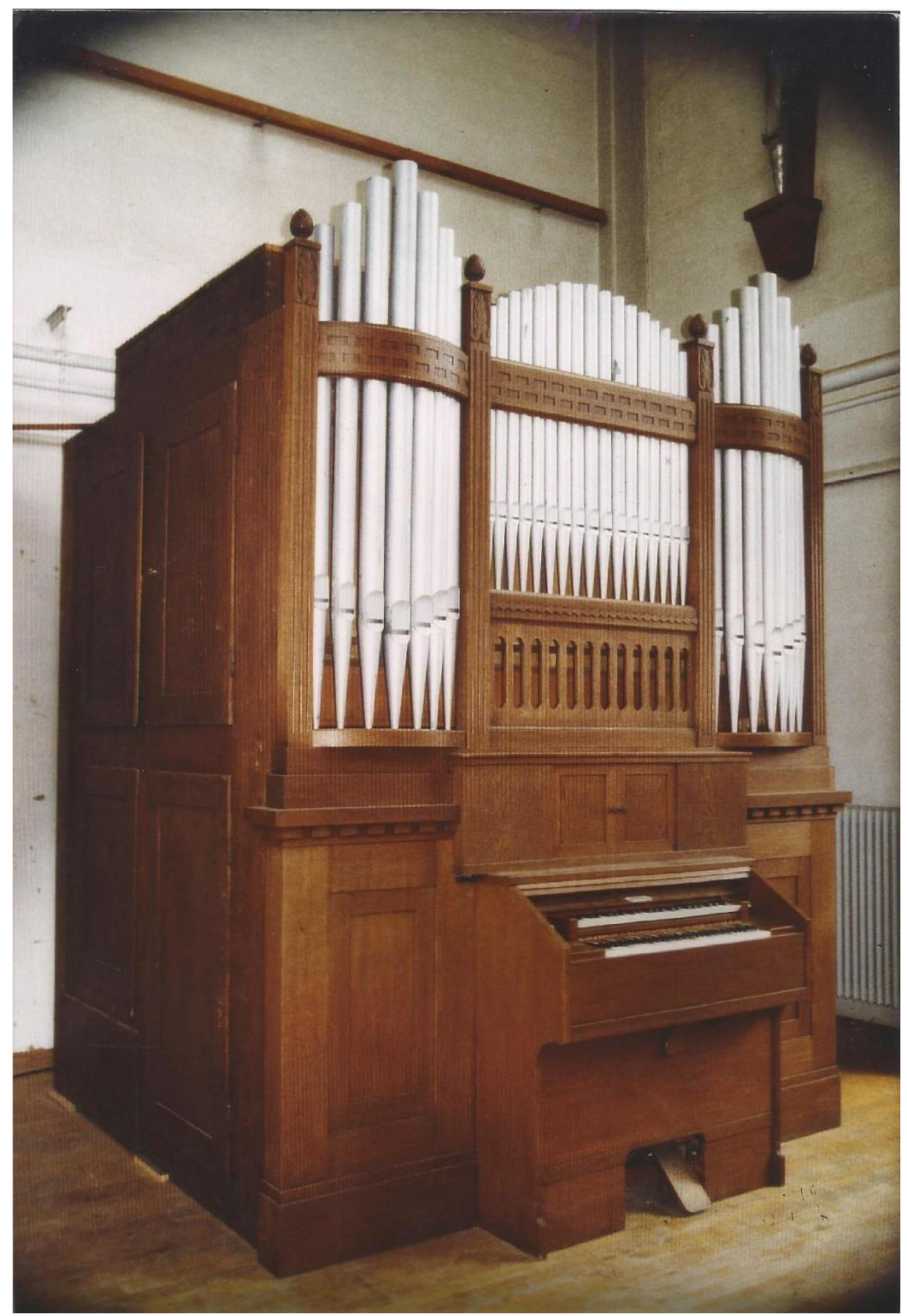

Fig. 1 The Panharmonium at the Steinmeyer factory in Oettingen, Bavaria (1924). (C) K. A. Psachos Archive) 


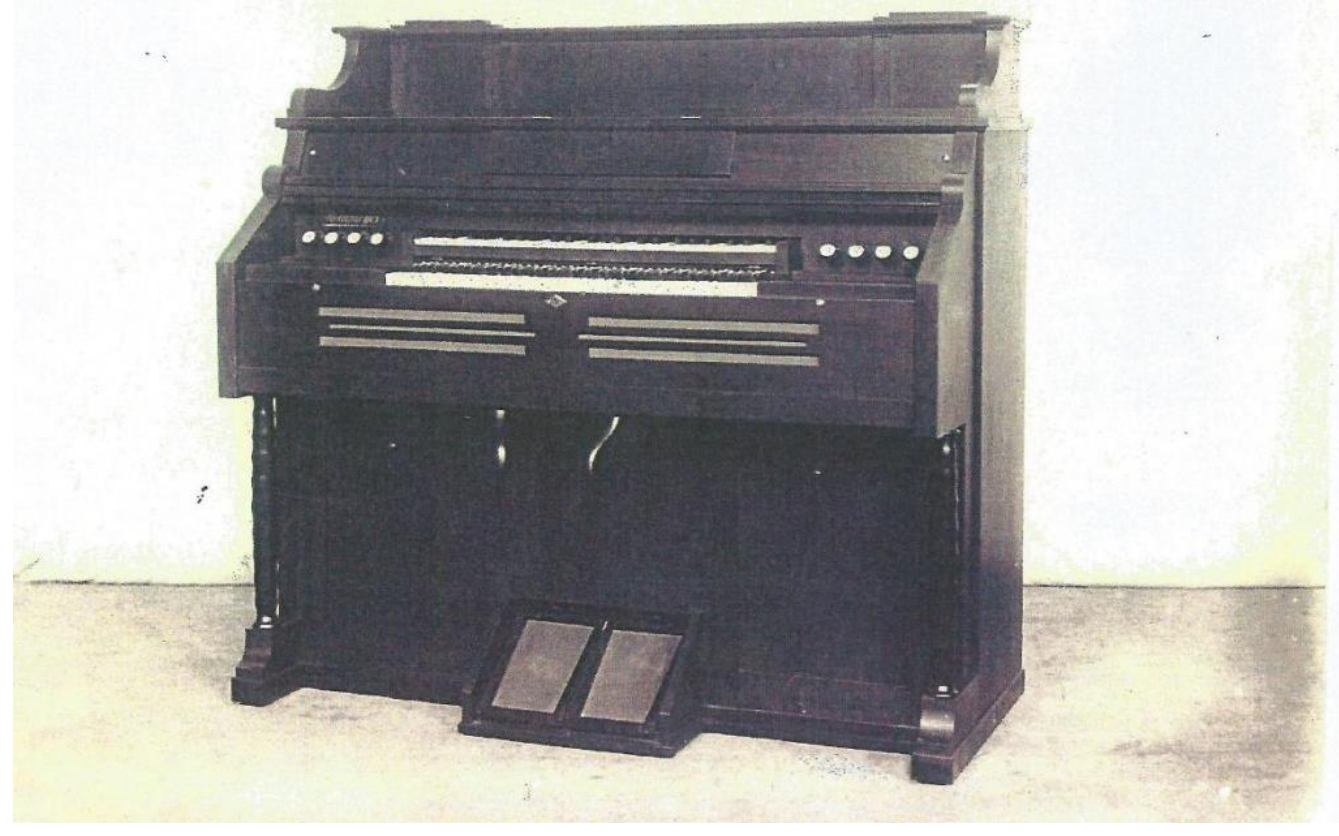

Fig. 2 The 4-octave Harmonium, Collection of the Cultural and Social Club of New Smyrna, Athens (ㄷ K. A. Psachos Archive)

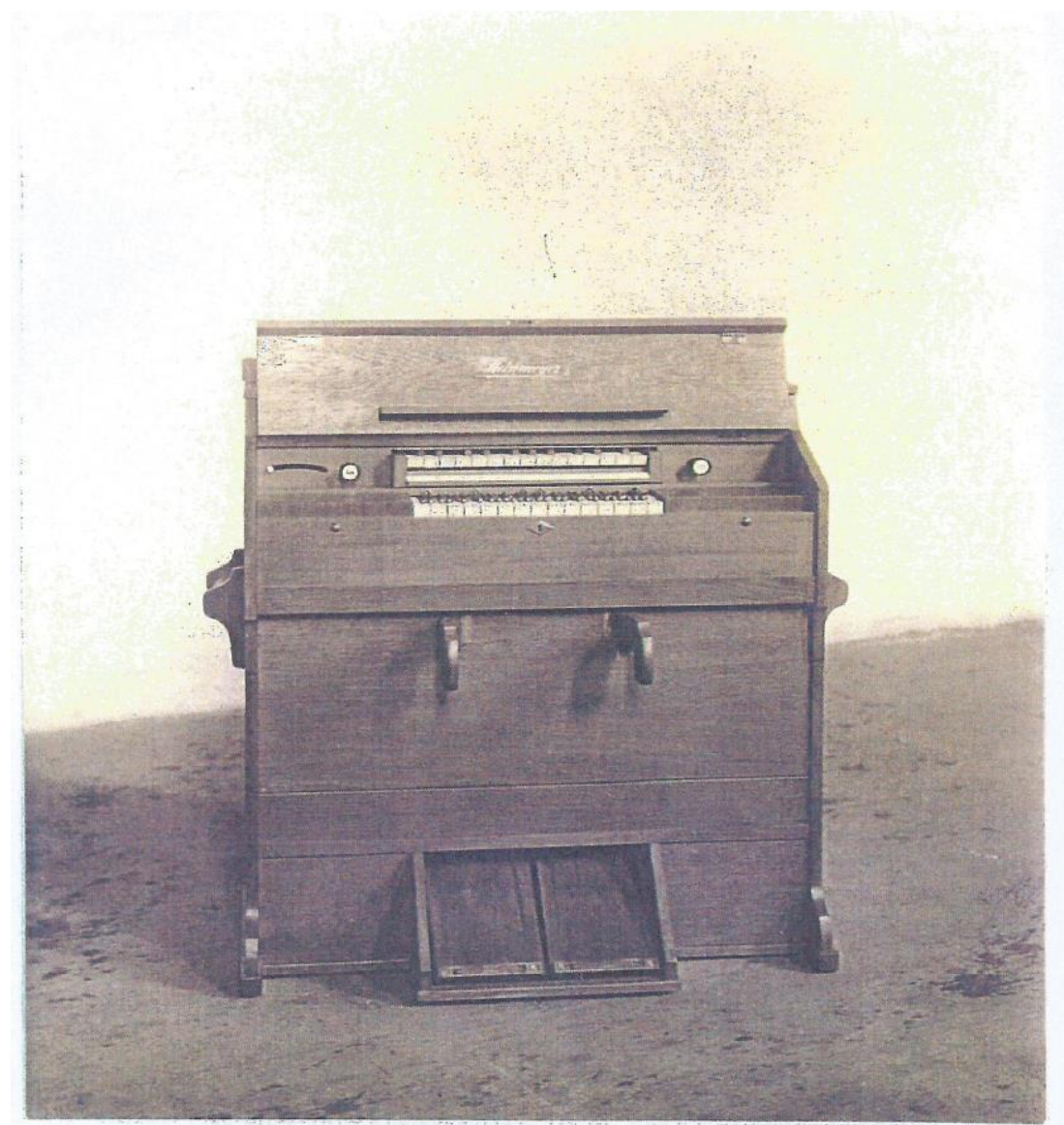

Fig. 3 The 2-octave Harmonium, Collection of the Hellenic Folklore Research Centre of the Academy of Athens. (C K. A. Psachos Archive) 


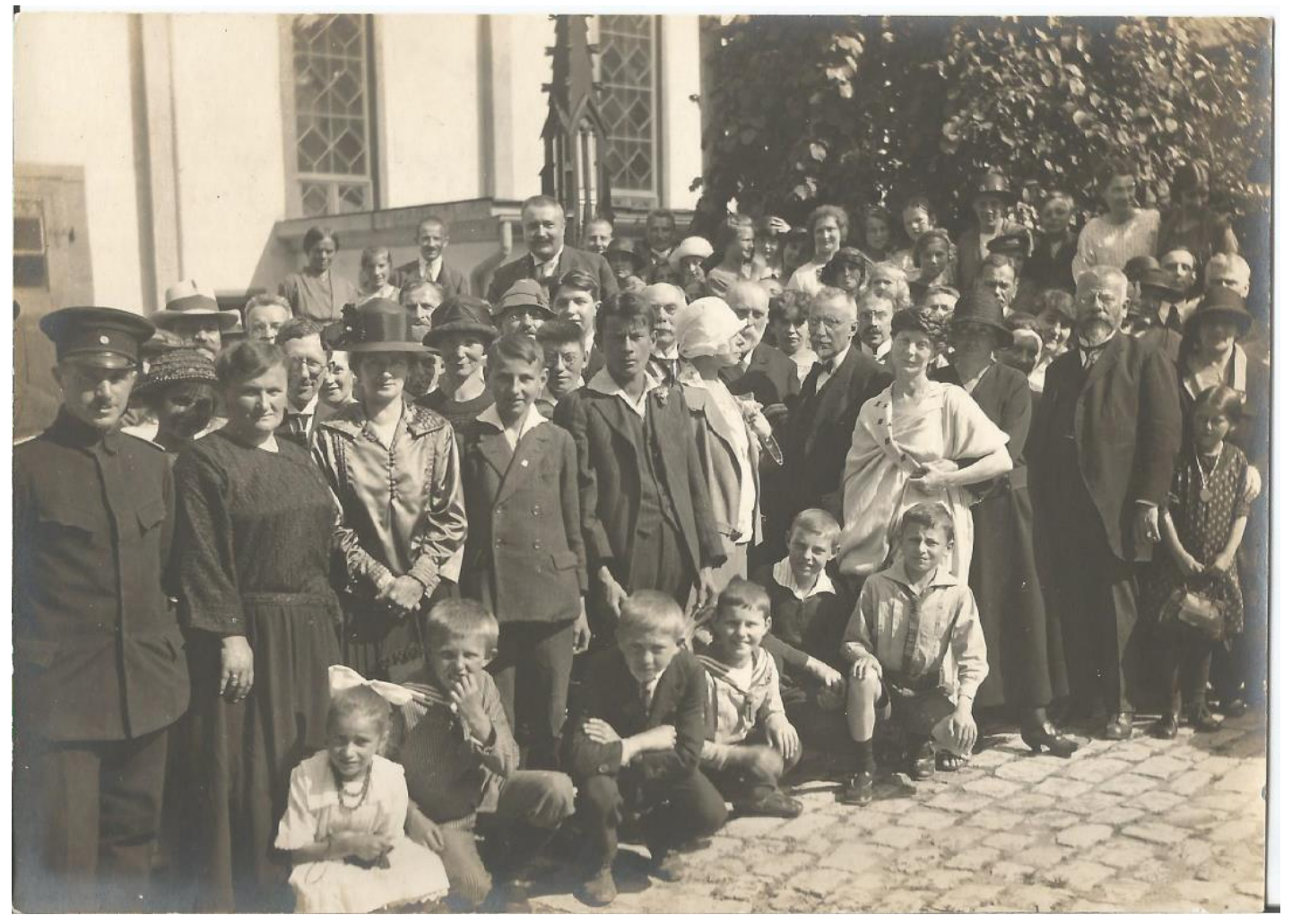

Fig. 4 The inauguration of the Panharmonium at the Steinmeyer factory (29 June 1924). Eva Palmer-Sikelianos is wearing a white tunic and holding the hand of a woman wearing a hat. K. A. Psachos is standing behind E. Palmer-Sikelianos wearing a suit, white shirt and a bow tie (C) K. A. Psachos Archive) 


\section{Musical examples [ex.]}

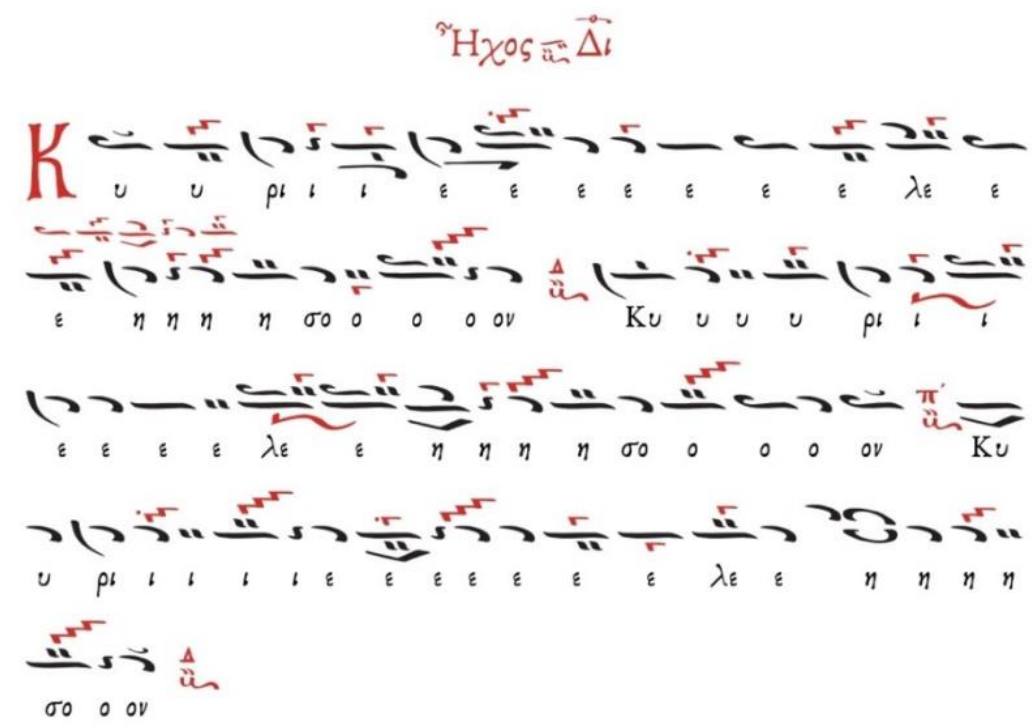

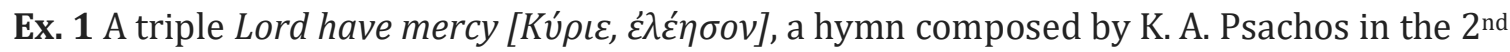
Mode of Byzantine Music, written on the cover page of one of his student notebooks; a contemporary transcription into the Byzantine Notation. (C) K. A. Psachos Archive) 


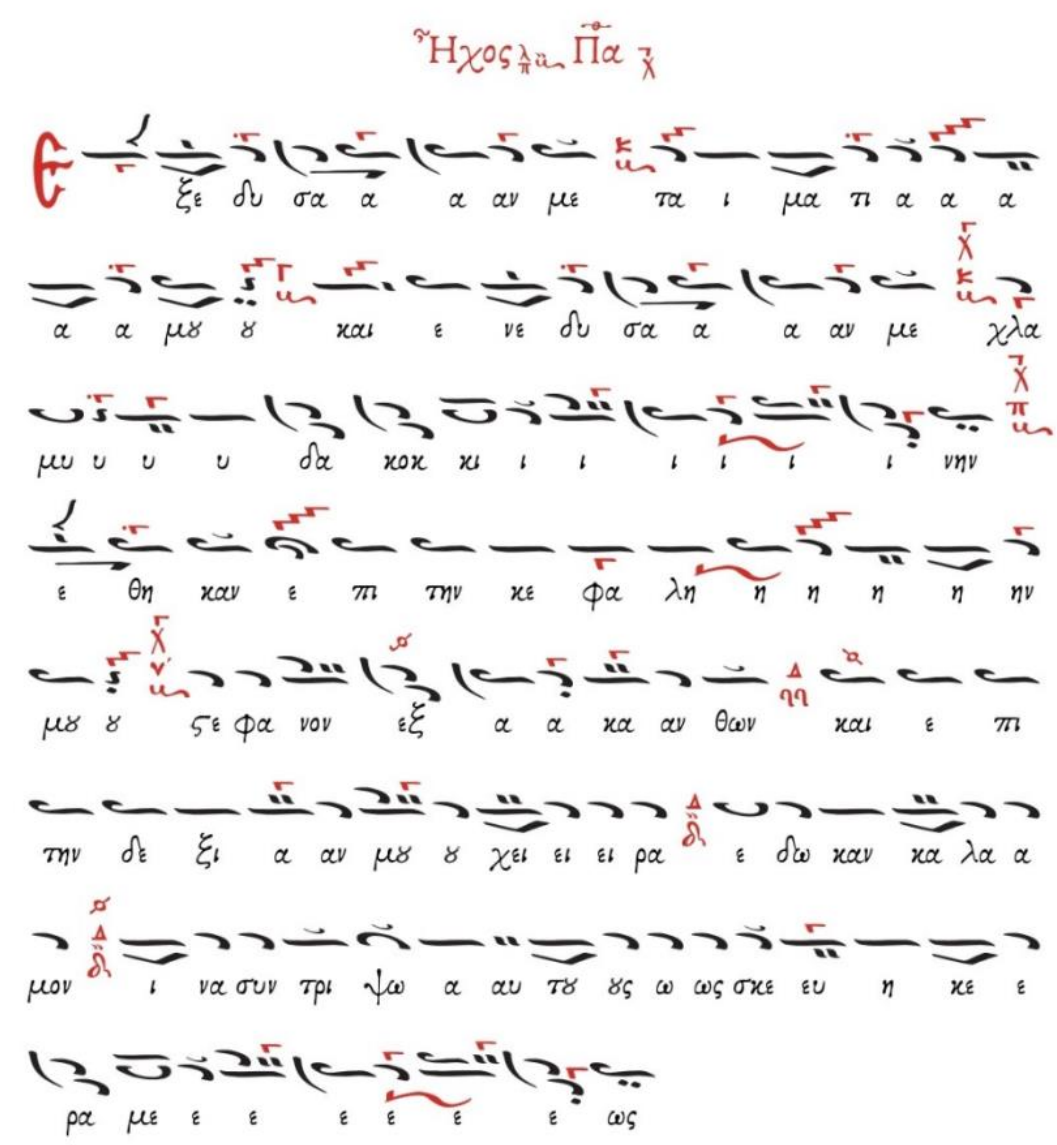

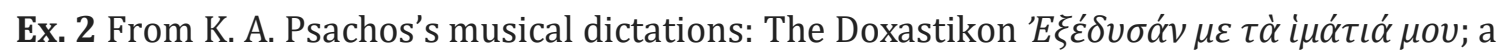
contemporary transcriprion into the Byzantine Notation, after a notational revision. (C) K. A. Psachos Archive) 
Hüzzâm Şark1

Hânende Nikoğos

Usûl Düyek
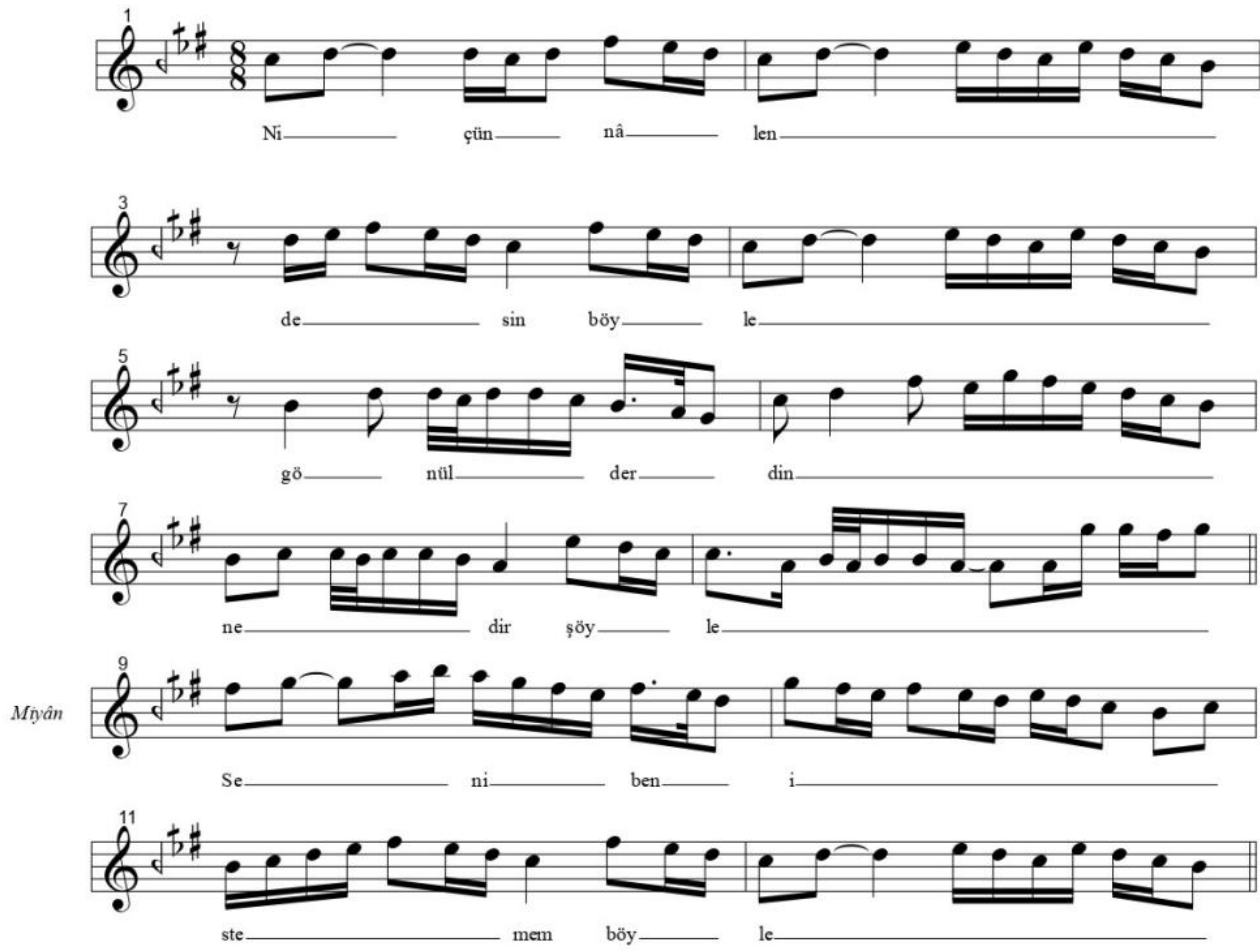

Nakarat
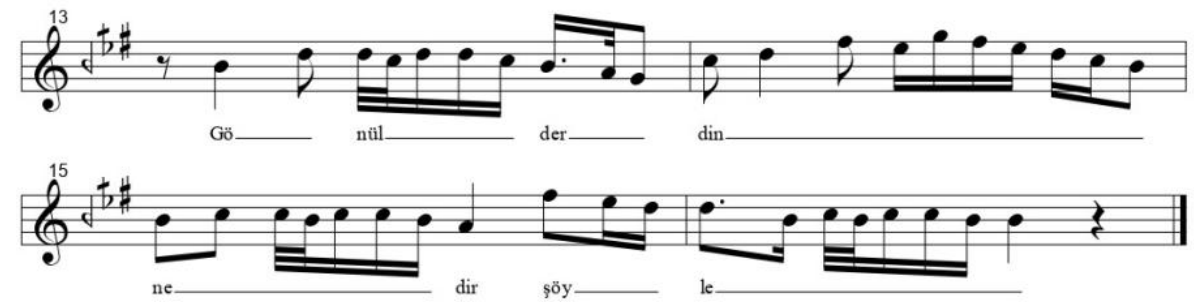

Niçün nâlendesin böyle

Gönül derdin nedir șöyle

Seni ben istemem böyle

Kimin aşkiyle nâlansın

Kimin hicriyle sûzansın

Neden böyle perişansın

Nedir sendeki bu halet

Buna vardir sebep elbet

Merak oldu bana vazet

Ex. 3 From K. A. Psachos's musical dictations; a musical score of a Şarkı composed by the

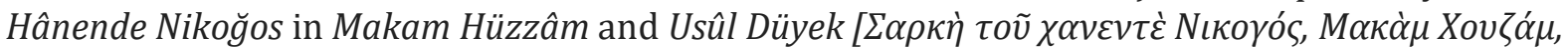

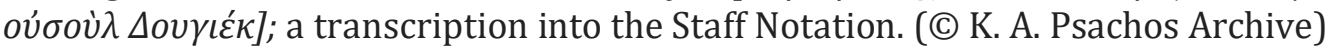

